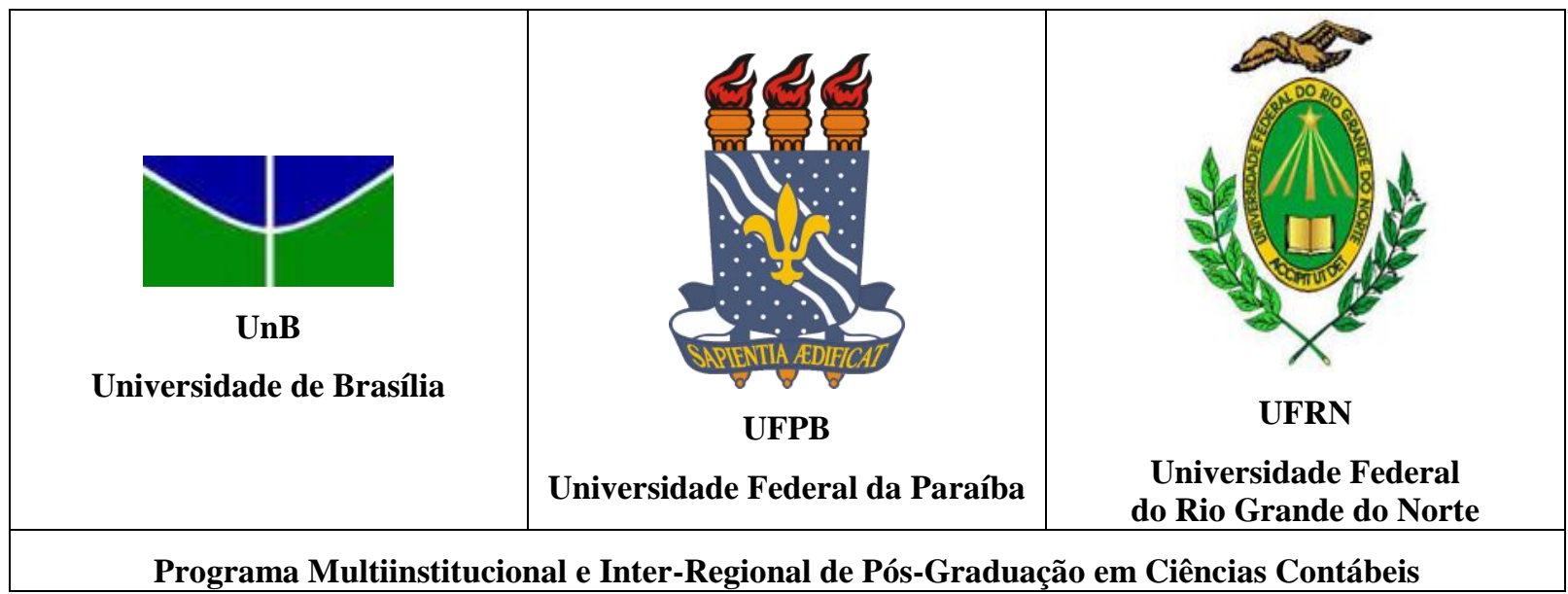

UTILIZAÇÃO DA PROVISÃO PARA CRÉDITOS DE LIQUIDAÇÃO DUVIDOSA PARA FINS DE GERENCIAMENTO DE RESULTADO NAS INSTITUIÇÕES FINANCEIRAS BRASILEIRAS E LUSO-ESPANHOLAS

Carlos Alberto Martins Silva 
Professor Doutor Ivan Marques de Toledo Camargo

Reitor da Universidade de Brasília

Professora Doutora Sônia Nair Báo

Vice-Reitora da Universidade de Brasília

Professor Doutor Jaime Martins de Santana

Decano de Pesquisa e Pós-Graduação

Professor Doutor Roberto de Goes Ellery Junior

Diretor da Faculdade de Economia, Administração, Contabilidade e Gestão de Políticas Públicas

Professor Doutor José Antônio de França

Chefe do Departamento de Ciências Contábeis e Atuariais

Professor Doutor Rodrigo de Souza Gonçalves

Coordenador Geral do Programa Multiinsticucional e Inter-regional de Pós-Graduação em Ciências Contábeis da UnB, UFPB e UFRN 
CARLOS ALBERTO MARTINS SILVA

\section{UTILIZAÇÃO DA PROVISÃO PARA CRÉDITOS DE LIQUIDAÇÃO DUVIDOSA PARA FINS DE GERENCIAMENTO DE RESULTADO NAS INSTITUIÇÕES FINANCEIRAS BRASILEIRAS E LUSO-ESPANHOLAS}

Dissertação apresentada como requisito parcial à obtenção do título de Mestre em Ciências Contábeis do Programa Multiinstitucional e Inter-Regional de Pós-Graduação em Ciências Contábeis da Universidade de Brasília, da Universidade Federal da Paraíba e da Universidade Federal do Rio Grande do Norte. Área de concentração: Mensuração Contábil.

Linha de pesquisa: Contabilidade e Mercado Financeiro.

Orientador: Dr. Jorge Katsumi Niyama. 
MU

Martins Silva, Carlos Alberto

Utilização da Provisão para Créditos de Liquidação Duvidosa para Fins de Gerenciamento de Resultado nas Instituições Financeiras Brasileiras e Luso Espanholas / Carlos Alberto Martins Silva;

orientador Jorge Katsumi Niyama. -- Brasília, 2016.

$115 \mathrm{p}$.

Dissertação (Mestrado - Mestrado em Ciências Contábeis) -- Universidade de Brasília, 2016.

1. Gerenciamento de Resultado. 2. Instituições Financeiras. 3. Provisão para créditos de liquidação duvidosa. 4. Brasil e Portuga-Espanha.

I. Niyama Katsumi, Jorge, orient. II. Título. 


$$
\begin{gathered}
\text { Universidade de Brasília - UnB } \\
\text { Universidade Federal da Paraíba - UFPB } \\
\text { Universidade Federal do Rio Grande do Norte - UFRN }
\end{gathered}
$$

Programa Multiinstitucional e Inter-Regional de Pós-Graduação em Ciências Contábeis

$$
\text { CARLOS ALBERTO MARTINS SILVA }
$$

\section{UTILIZAÇÃO DA PROVISÃO PARA CRÉDITOS DE LIQUIDAÇÃO DUVIDOSA PARA FINS DE GERENCIAMENTO DE RESULTADO NAS INSTITUIÇÕES FINANCEIRAS BRASILEIRAS E LUSO-ESPANHOLAS}

Dissertação apresentada como requisito parcial à obtenção do título de Mestre em Ciências Contábeis do Programa Multiinstitucional e Inter-Regional de Pós-Graduação em Ciências Contábeis da Universidade de Brasília, da Universidade Federal da Paraíba e da Universidade Federal do Rio Grande do Norte. Área de concentração: Mensuração Contábil. Linha de pesquisa: Contabilidade e Mercado Financeiro.

Orientador: Prof. Dr. Jorge Katsumi Niyama.

Banca Examinadora:

Prof. Dr. Jorge Katsumi Niyama - Presidente

Programa Multiinstitucional e Inter-Regional de Pós-Graduação em Ciências Contábeis UnB/UFPB/UFRN

Prof. Dr. Jomar Miranda Rodrigues - Membro Interno não vinculado Programa de Pós Gradução em Ciências Contábeis da Univerisdade de Brasília (UnB)

Profa. Dra. Isabel Maria Estima Costa Lourenço - Membro Externo ISCTE/IUL/PT 
À minha mãe, esposa e filha. 


\section{AGRADECIMENTOS}

A Universidade de Brasília (UnB) e ao Programa Multiinstitucional e Inter-Regional de Pós-Graduação em Ciências Contábeis por este período de crescimento.

Ao Professor Doutor Jorge Katsumi Niyama, meu orientador, pela confiança, apoio, e disponibilidade em me orientar e por suas contribuições. Registro minha admiração!

Ao professor Doutor José Alves Dantas pelas contribuições importantes durante a pesquisa. Aos professores Doutor Rodrigo de Souza Gonçalves, Doutor Jomar Miranda Rodrigues e Doutora Isabel Maria Estima Costa Lourenço, pelas contribuições diversas durante esse trajeto.

A minha família, que me apoiou incondicionalmente desde o início. 
"Admitir que o não-verdadeiro é a condição da vida, é opor-se audazmente ao sentimento que se tem habitualmente dos valores". 


\section{RESUMO}

O presente estudo teve por objetivo verificar a adoção de gerenciamento de resultado nas instituições financeiras brasileiras e luso-espanholas com base nas despesas de provisão para créditos de liquidação duvidosa. O desempenho das instituições financeiras é importante para avaliar o sistema financeiro, assim a Contabilidade é um dos instrumentos mais relevantes para o acompanhamento do segmento. O gerenciamento de resultado no sistema bancário é especialmente delicado em função da efetivação dos riscos que as instituições financeiras são expostas e potenciais impactos, como restrição de crédito e comprometimento do segmento. A literatura internacional evidencia que a administração de bancos faz uso de sua discricionariedade na constituição de provisões sobre as operações de créditos com o objetivo de gerenciar resultados. Neste sentido, a pesquisa em questão fez uso da análise das acumulações discricionárias conjuntamente com a estimação em dois estágios, com base na amostra de instituições financeiras brasileiras e luso-espanholas no período de junho de 2009 a dezembro de 2014. Como resultado, foi possível observar que as instituições financeiras brasileiras e luso-espanholas fazem uso das despesas com provisões sobre as operações de créditos visando o gerenciamento de resultados.

Palavras-chave: Gerenciamento de resultado. Instituições financeiras. Provisão para créditos de liquidação duvidosa. Brasil e Portugal-Espanha. 


\begin{abstract}
Banks have an important role in the financial system in general, and accounting is an indispensable mean to track this segment performance. Studying earnings management in the banking system is especially delicate, due to the potential impact this subject may cause in the banks. International literature shows that the bank managers use discretion when provisioning loans in order to manage results. This study aims to verify earnings management adoption in Brazilian and Portuguese-Spanish banks through the analysis of allowance for doubtful accounts. The research approach used was the analysis of discretionary accruals together with two-stage estimation. The sample was composed of Brazilian, Portuguese and Spanish financial institutions discretionary accruals during the period of june 2009 to December 2014. The survey results indicated that the three countries financial institutions use expenses on credit provisions to manage results.
\end{abstract}

Keywords: Earnings management. Financial institutions. Loan loss provision. Brazil and Portugal-Spain. 


\section{LISTA DE QUADROS}

Quadro 1 - Decisões de gerenciamento de resultado.............................................. 39

Quadro 2 - $\quad$ Análise de sinais esperados e resultados.............................................. 69

Quadro 3 - Categorias dos riscos de insolvências..................................................... 104

Quadro 4 - Grupos da classificação de operações.................................................... 108

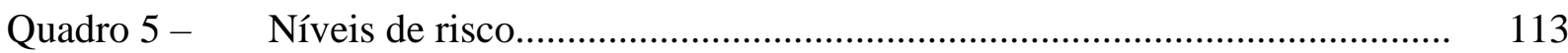




\section{LISTA DE TABELAS}

Tabela 1 - Teste Raiz Unitária - Modelo (1)....................................................... 52

Tabela 2 - $\quad$ Teste Durbin Watson - Modelo (1)....................................................... 53

Tabela 3 - $\quad$ Resultados dos testes de inflação entre as variáveis - Modelo (1)............. 53

Tabela $4-\quad$ Estatística descritiva das variáveis utilizadas nos modelos (Brasil)........... 55

Tabela 5 - Estatística descritiva das variáveis utilizadas nos modelos (Portugal-

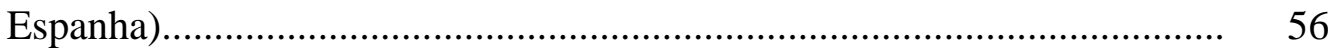

Tabela 6 - $\quad$ Resumo dos resultados estatísticos - Modelo (1) - Brasil......................... 57

Tabela 7 - Resumo dos resultados estatísticos - Modelo (1) - Portugal-Espanha....... 60

Tabela 8 - Resumo dos resultados estatísticos - Modelo (1) - Método de erros padrões seccionais SUR (PCSE) - Brasil................................................. 63

Tabela 9 - Resumo dos resultados estatísticos - Modelo (1) - Método de erros padrões seccionais SUR (PCSE) - Portugal-Espanha.............................. 65

Tabela 10 - Resumo comparativo dos resultados - Amostras brasileiros e lusoespanholas - Modelo (1)..................................................................... 71

Tabela 11 - Teste Raiz Unitária - Modelo (2)............................................................. 74

Tabela 12 - Teste Durbin Watson - Modelo (2)....................................................... 75

Tabela 13 - Resultados dos testes de inflação entre as variáveis - Modelo (1)............. 75

Tabela 14 - Resultados Modelo (2) - Amostras brasileiras e luso-espanholas.............. 77

Tabela 15 - Resultados - Modelo (2) - Amostras brasileiras e luso-espanholas SUR

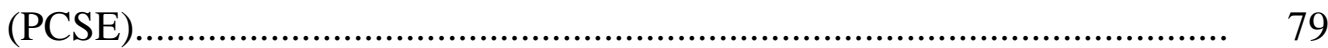

Tabela 16 - Classificação dos créditos em classes de riscos.......................................... 102

Tabela 17 - Taxas de perda aplicáveis aos ativos sem risco identificável..................... 109

Tabela 18 - $\quad \beta$ e $\alpha$ das classificações de risco................................................................ 111

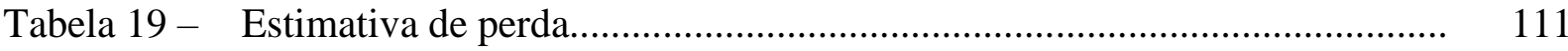

Tabela 20 - Percentual de provisão de acordo com o nível de risco............................... 114 


\section{LISTA DE ABREVIATURAS E SIGLAS}

\begin{tabular}{|c|c|}
\hline $\mathrm{ADF}$ & - Teste Dickey-Fuller Aumentado \\
\hline Art. & - Artigo \\
\hline BACEN & - Banco Central do Brasil \\
\hline BANIF Invest & - Banco de Investimento S.A. \\
\hline $\mathrm{BDE}$ & - Banco da Espanha \\
\hline BES & - Banco Espírito Santo S.A. \\
\hline BESI & - Banco Espírito Santo Investimento S.A. \\
\hline BPN & - Banco Português de Negócios S.A. \\
\hline $\mathrm{CMN}$ & - Conselho Monetário Nacional \\
\hline $\mathrm{CNC}$ & - Comissão de Normalização Contabilística \\
\hline DW & - Durbin Watson \\
\hline EUA & - Estados Unidos da América \\
\hline FASB & - Financial Accounting Standards Board \\
\hline FIV & - Fator de Inflação de Variância \\
\hline FMI & - Fundo Monetário Internacional \\
\hline GR & - Gerenciamento de Resultado \\
\hline IASB & - International Accounting Standards Board \\
\hline IFRS & - International Financial Reporting Standards \\
\hline IPO & - Initial Public Offering \\
\hline $\mathrm{N}$. & - Número \\
\hline NCA & - Normas Contábeis Ajustadas (Portugal) \\
\hline PCLD & - Provisão para Créditos de Liquidação Duvidosa \\
\hline PIB & - Produto Interno Bruto \\
\hline POC & - Plano Oficial de Contabilidade (Portugal) \\
\hline PP & - Teste Phillips-Perron \\
\hline ROI & - Retorno sobre o investimento \\
\hline SFN & - Sistema Financeiro Nacional \\
\hline SNC & - Sistema de Normalização Contabilística (Portugal) \\
\hline TVM & - Títulos e Valores Mobiliários \\
\hline UE & - União Europeia \\
\hline UFPB & - Universidade Federal da Paraíba \\
\hline
\end{tabular}


UFRN

$\mathrm{UnB}$

- Universidade Federal do Rio Grande do Norte

- Universidade de Brasília 


\section{SUMÁRIO}

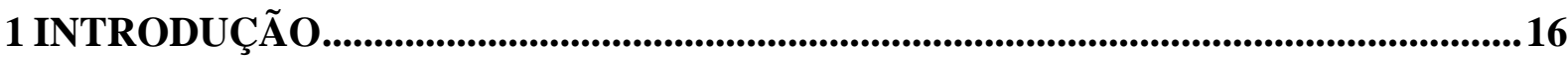

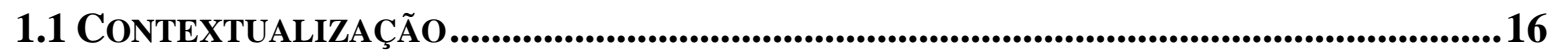

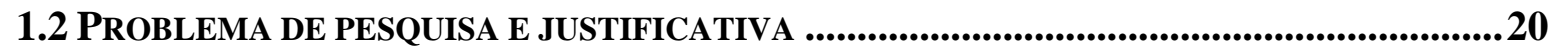

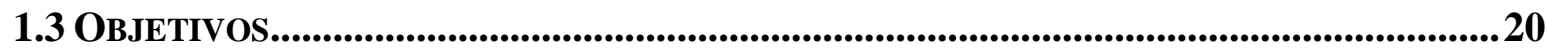

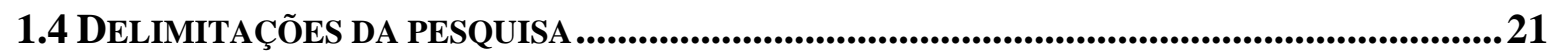

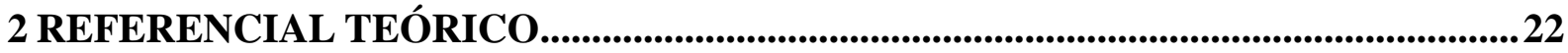

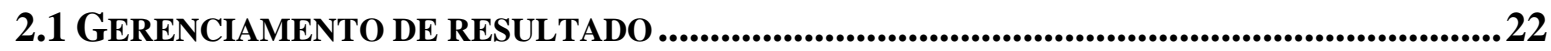

2.2 GERENCIAMENTO DE RESULTADO EM INSTITUIÇÕES FINANCEIRAS..............................25

2.3 PROCEDIMENTOS DE GERENCIAMENTO DE RESULTADO ...................................................37

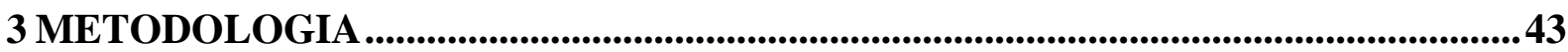

3.1 FoRMULAÇÃo dO MODELO PARA AVALIAÇÃo DE GERENCIAMENTO DE RESULTADO. 44

3.2 ANÁLISE DE GERENCIAMENTO DE RESULTADO ............................................................48

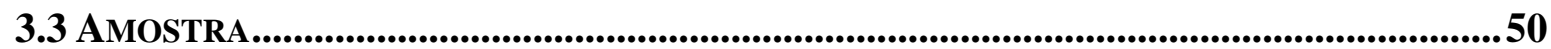

4 ANÁLISE DOS RESULTADOS DA PESQUISA ..........................................................51

4.1 TESTES DO MODELO DE PRIMEIRO ESTÁGIO ..................................................................51

4.2 ESTATÍSTICA DESCRITIVA DAS VARIÁVEIS UTILIZADAS NOS MODELOS - AMOSTRA

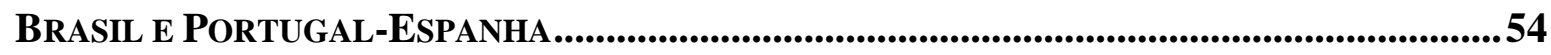

4.3 AnÁlise dos ReSUltados eSTimados - MOdelo (1) - AMOSTRA Brasil...............57

4.4 ANÁlise dos resultados estimados Modelo (1) - Amostra Portugal-

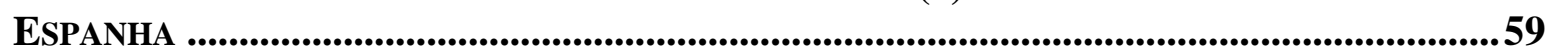

4.5 PROCEDIMENTOS DE ROBUSTEZ PRIMEIRO ESTÁGIO...............................................62

4.6 ANÁLISE COMPARATIVA dOS RESUlTAdOS ESTIMAdOS MOdELO (1) - BRASIL E

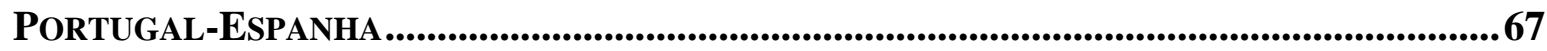

4.7 TESTES DO MODELO DE SEGUNDO ESTÁGIO ....................................................73

4.8 Análise dos Resultados estimados Modelo (2) - Brasil e Portugal.............. 76

4.9 PROCEDIMENTOS DE ROBUSTEZ SEGUNDO ESTÁGIO................................................78

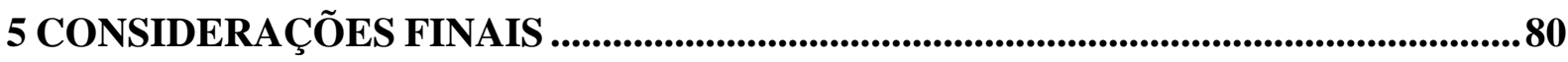

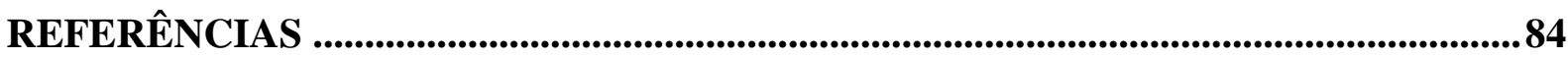

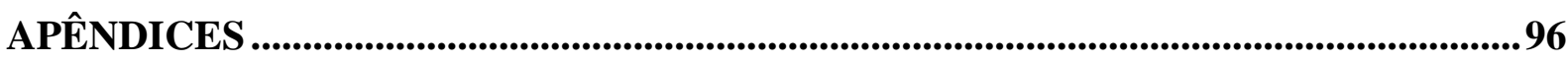

APÊNDICE A - LISTA DOS BANCOS UTILIZADOS NA PESQUISA ............................97

APÊNDICE B - REPRESENTAÇÃO DA AMOSTRA NO SISTEMA FINANCEIRO ..99

APÊNDICE C - PROVISÃO PARA CRÉDITOS DE LIQUIDAÇÃO DUVIDOSA EM INSTITUIÇÕES FINANCEIRAS ...........................................................................100 


\section{INTRODUÇÃO}

\subsection{Contextualização}

Os sistemas bancários têm papel importante no sistema financeiro em geral, e a Contabilidade é, sem dúvida, um importante instrumento em prol daqueles que desejam acompanhar o desempenho do segmento. As informações que são preparadas estão sujeitas a influência e ao julgamento de seus responsáveis e preparadores nas estimativas e mensurações realizadas a partir das perspectivas em relação à operação do negócio e apresentação de seus resultados. Apenas por este fato, têm-se aí uma possibilidade de parcialidade. O gerenciamento de resultado surge na esteira da utilização de determinadas alternativas discricionárias nas escolhas de procedimentos por meio de julgamentos que constituem um desafio à proteção de informações efetivamente relevantes e úteis aos usuários.

As demonstrações financeiras têm diversos usuários, e nas instituições financeiras, os reguladores observam importantes aspectos para o sistema financeiro com base em tais informações. Para as instituições financeiras, têm-se a obrigação da manutenção dos níveis mínimos de capital - aspecto fundamental que garante: 1) a estrutura de captação de recursos que considerem riscos atrelados à instituição e ao sistema financeiro; 2) a solidez de sua estrutura patrimonial, além dos resultados obtidos. Assim, o gerenciamento de resultado é uma prática possível no alcance de tais objetivos, e a modalidade conhecida como suavização dos resultados (income smoothing) é procedimento de interesse para as instituições financeiras em relação ao desempenho esperado.

Um dos quesitos para o efetivo funcionamento do sistema financeiro é a necessidade de transparência perante o mercado, investidores e demais interessados. Os reguladores estabelecem normas quanto à forma de apresentação (reporting) e evidenciação de informações complementares a serem realizadas pelas instituições financeiras, em especial, no que tange à situação patrimonial e financeira.

As instituições financeiras, por suas características específicas de intermediação, têm sua estrutura de ativos formada majoritariamente por operações de crédito. Com base no relatório "50 Maiores Bancos e o Consolidado do Sistema Financeiro Nacional”, divulgado pelo Banco Central do Brasil (BACEN), é possível observar que mais de 55\% (cinquenta e cinco por cento) dos ativos do Sistema Financeiro Nacional (SFN) é formado pelos ativos mencionados em 31 de dezembro de 2014. As instituições financeiras em Portugal, a partir dos dados divulgados pelo Banco de Portugal (equivalente ao BACEN brasileiro), por meio 
do relatório "b391 - Balanço Agregado do Sistema Bancário - Atividade Consolidada NIC/NCA", possuem aproximadamente 59\% (cinquenta e nove por cento) dos ativos do sistema bancário português compostos por operações de crédito e títulos e valores mobiliários. No Sistema Financeiro espanhol, conforme o relatório da Associação Espanhola de Bancos, mais de 57\% (cinquenta e sete por cento) dos ativos são operações de crédito.

Para Niyama e Gomes (2012), as operações de crédito são as principais fontes de receita das instituições financeiras. O resultado líquido das transações com operações de crédito é impactado (mediante o ajuste das provisões para créditos de liquidação duvidosa), e é na mensuração da provisão supramencionada que podem ocorrer práticas de gerenciamento de resultados, uma vez que cabe o julgamento do nível de risco do cliente e da operação para sua estimativa.

Dada a estrutura de ativos das instituições financeiras ser majoritariamente composta por títulos e valores mobiliários e operações de crédito, a utilização dos mesmos para o gerenciamento de resultado é corroborada por pesquisas, como a expressa por Dechow, Weili e Schrand (2010). Martinez (2001) classifica os incentivos para gerenciamento de resultado em três categorias, a saber: 1) motivações vinculadas ao mercado de capitais; 2) motivações contratuais; e, 3) motivações regulamentares e custos políticos.

É importante ressaltar que o gerenciamento de resultado difere da questão da fraude, uma vez que o primeiro opera dentro dos limites e das possibilidades de aplicação de premissas e regras nas escolhas dos procedimentos contábeis. Conforme Martinez (2001), o gerenciamento de resultado opera dentro dos limites prescrevidos pela regulamentação contábil, onde se tem a possibilidade de aplicação do julgamento. Assim, onde as normas contábeis facultam determinada discricionariedade, os responsáveis pela elaboração das informações contábeis podem realizar escolhas que poderão não refletir a representação fidedigna das transações do negócio, divergindo da representação da essência econômica - em função de incentivos diversos que podem existir para reportar uma posição específica. Park e Shin (2004) corroboram que é costume se aproveitar das alternativas das práticas contábeis para realizar o gerenciamento de resultado e, por consequência, aumentar a assimetria informacional.

O gerenciamento de resultado também pode ocorrer sem relação alguma com qualquer tipo de alteração contábil, mas por meio de decisões em transações concretas, conforme Dechow e Skiner (2000). Neste sentido, têm-se os seguintes exemplos: a) por meio de retardo de vendas; b) aumentos de despesas não operacionais; e, c) aumento de receitas não operacionais (venda de ativos permanentes etc.). 
A presente pesquisa teve por norte o gerenciamento de resultado por meio provisão para créditos de liquidação duvidosa sobre as operações de crédito, com foco nos sistemas bancários brasileiro e luso-espanhol. A relação luso-espanhola ao longo dos séculos conviveu com teorias pró-iberismo e anti-iberistas, com discussões em relação ao desenvolvimento econômico no contexto de unificação e em separado. Ou seja, pela história lusa confundir-se com a espanhola, a análise aqui se fez de modo conjunto - instituições financeiras portuguesas e espanholas.

Conforme Mata e Valério (2011) a unificação (portuguesa) era um sonho antigo dos governantes da Península Ibérica, a realização da unificação em 1580 provou que ainda havia apoio dos principais grupos da sociedade portuguesa. Ainda nesse contexto, a Igreja Católica estava satisfeita em ver o principal defensor da fé católica na liderença. A burguesia portuguesa estava feliz com a perspectiva de serem autorizados a participar na exploração economica dos bens do "novo mundo".

A fim de traçar um paralelo de quão próxima é a relação histórica de Portugal e Espanha, conforme Silva (2011), no período de 1581 a 1598, aquelas nações estavam unidas sob uma única monarquia - período marcado por diversos conflitos em território português por divergências com a liderança espanhola, o que gerou a restauração da independência portuguesa no dia 1 de dezembro de 1640. Aquele autor destaca alguns estudiosos que, na história das duas nações, argumentam pela unificação e outros pela manutenção da separação entre as mesmas. Do ponto de vista econômico, Silva destaca que Portugal e Espanha se veem unidos, mais do que antes, na mesma dinâmica de economia, exemplificando a criação de uma rede ibérica de trabalho.

A análise de gerenciamento de resultado no contexto das instituições financeiras brasileiras e luso-espanholas se dá em função da relação histórica entre os países e a possível influência mútua pelos aspectos culturais. Neste sentido, a relação entre Brasil e Portugal é importante desde o início e, segundo Freyre (2006), a característica de diversidade e de mobilidade do Brasil são desdobramentos do legado português a sua anterior colônia. Adicionalmente, têm-se diversos outros aspectos que até hoje guardam grande influência e peculiaridades entre as duas as nações, como, por exemplo, a influência da religião nos mais diversos campos sociais. Em relação a Portugal, não há como afastar a relação intima com a Espanha - país este que guarda intensas relações históricas e econômicas.

No que se refere a relação entre Brasil e Portugal, Mata e Valério (2011), afirmam que a independência econômica do Brasil com o fim do pacto colonial em 1808, teve duas consequências de longo alcance para Portugal: i) a perda da posição de intermediário no 
comércio exterior brasileiro e ii) a perda de um mercado protegido para a exportação de mercadorias portuguesas. Ainda conforme os autores, a independência econômica do Brasil foi prejudicial para a prosperidade da economia portuguesa.

No que se refere às práticas contábeis, as instituições financeiras brasileiras, a partir da Resolução n. 3.786/2009 do Conselho Monetário Nacional (CMN) do Brasil, passaram a apresentar demonstrações financeiras diferenciadas, elaborando demonstrações com as práticas aprovadas pelo BACEN, além de fazer uso de práticas contábeis internacionais.

Em Portugal, o Decreto-Lei n. 158/2009, de 13 de julho de 2009, aprovou o Sistema de Normalização Contabilística (SNC), passando a ter a necessidade de aplicação das normas internacionais de Contabilidade para entidades que tenham negociação de valores mobiliários. Neste sentido, o Aviso do Banco de Portugal n. 1/2005 determina que se apliquem as normas internacionais de Contabilidade na elaboração das demonstrações financeiras, quer em base individual, quer em base consolidada, para determinadas instituições financeiras.

Na Espanha, o Regulamento n. 1.606/2002 determinou o uso obrigatório das normas internacionais na União Europeia (UE). Ali, a autoridade bancária - o Banco da Espanha (BDE) (análogo à estrutura portuguesa e brasileira) - publicou a Circular n. 04/2004, que adapta a regulamentação ao setor financeiro para o International Financial Reporting Standards (IFRS), que estabelece a aplicação reservada às demonstrações financeiras consolidadas.

A aplicação de procedimentos de gerenciamento de resultado pode comprometer a compreensão do usuário da informação contábil. Entretanto, contrapondo-se àquela posição, Parfet (2000) ressalta a existência de Good Earnings Management, onde o gerenciamento de resultado está ligado às boas práticas, maximizando os resultados e obtendo os objetivos estimados.

Os objetivos que motivam o gerenciamento de resultado, em geral, não se relacionam no fornecimento de informações contábeis neutras aos usuários das demonstrações financeiras. As instituições financeiras, tendo parte representativa de seus ativos compostos por operações de crédito, os quais são suscetíveis aos mais variados tipos de ajustes para apresentar o valor líquido de realização por meio da provisão para crédito de liquidação duvidosa, proporcionam oportunidades para o gerenciamento de resultado.

Diante do exposto, a pesquisa teve por objetivo analisar o gerenciamento de resultado de instituições financeiras, avaliando as práticas, semelhanças e diferenças entre as instituições financeiras brasileiras e luso-espanholas, buscando evidências em ambos os 
contextos e resultados de eventual aplicação de gerenciamento de resultado, considerando as provisões para créditos de liquidação duvidosa.

A pesquisa justifica-se, pois, poucos estudos avaliaram o gerenciamento de resultado no contexto de sistemas financeiros diferentes, existindo pouca literatura sistematizada sobre o gerenciamento de resultado em instituições financeiras em ambientes diferentes.

\subsection{Problema de pesquisa e justificativa}

O presente estudo teve por objetivo verificar a existência de evidências de que as instituições financeiras que atuam no Brasil, Portugal e Espanha, fazem uso da contabilização da provisão para créditos de liquidação duvidosa referentes às operações de crédito para gerenciamento de resultado.

Conforme já mencionado, os padrões contábeis vigentes nos sistemas financeiros podem ser utilizados para melhorar a representação da situação patrimonial das instituições financeiras. Assim, o gerenciamento de resultado representa o aproveitamento da flexibilidade existente nas normas e práticas contábeis em prol da adoção de medidas variadas para determinado evento, de modo a mover o resultado.

\subsection{Objetivos}

A pesquisa em questão teve por objetivo avaliar a possível adoção da prática de gerenciamento de resultado nas instituições financeiras no Brasil, Portugal e Espanha, na contabilização da provisão para créditos de liquidação duvidosa. A avaliação se dá, empiricamente, verificando se o componente discricionário das despesas com provisão para créditos de liquidação duvidosa é utilizado para gerenciamento de resultado. A análise de gerenciamento de resultado em sistemas financeiros e em países diferentes possui pouca literatura sistematizada, e a análise poderá contribuir para as pesquisas sobre gerenciamento de resultado em ambientes diferentes.

Adicionalmente, o presente estudo também teve por objetivo, de forma complementar, analisar os resultados da abordagem empírica entre as instituições financeiras brasileiras e luso-espanholas, buscando avaliar as características relativas às mesmas e os resultados de possível gerenciamento de resultado. 


\subsection{Delimitações da pesquisa}

A pesquisa limitou sua abrangência aos aspectos de gerenciamento de resultado relacionados com a provisão para créditos de liquidação duvidosa de operações de crédito, para a amostra das instituições financeiras brasileiras e luso-espanholas.

Não foi objeto do trabalho a análise, a revisão ou as discussões em torno de qualidade ou viés das normas e regras contábeis. Adicionalmente, também não foi objeto a análise de outras variáveis contábeis a respeito de gerenciamento de resultado.

Os dados das instituições financeiras portuguesas são divulgados pelo Banco de Portugal de forma consolidada desde o exercício de 1997. Assim, na presente pesquisa, fez-se uso dos dados divulgados pela Associação Portuguesa de Bancos, que divulga as informações por instituições associadas desde o exercício de 2009, bem como as demonstrações financeiras semestrais e anuais do período de 2009 até dezembro de 2014. De fato, a pesquisa teve limitação de disponibilidade de dados do sistema bancário português ao longo do tempo. Entretanto, as informações disponibilizadas pela Associação supramencionada perfazem aproximadamente $96 \%$ (noventa e seis por cento) dos ativos do sistema bancário português. Os dados utilizados são de dezembro de 2009 até dezembro de 2014, semestralmente. 


\section{REFERENCIAL TEÓRICO}

\subsection{Gerenciamento de resultado}

O resultado auferido por uma instituição financeira é o parâmetro de desempenho financeiro e econômico que é utilizado por diversos interessados para conduzir suas decisões de relação institucional. Assim, os stakeholders, tais como os investidores, os empregados e o próprio Estado, fazem uso da medida para balizar seu vínculo.

O gerenciamento de resultado deriva do uso de oportunidades existentes nos critérios para apuração do resultado pelos administradores, que podem alterar o resultado de forma oportunista, de modo a enviesar informações aos usuários.

Em geral, o gerenciamento de resultados é uma prática que faz uso de um método contábil específico para alterar números, conforme Wong (2011). A definição frequentemente utilizada na literatura para o gerenciamento de resultados é a dada por Healy e Whalen (1999, p. 368), conforme se segue:

\footnotetext{
Gerenciamento de resultados ocorre quando os gerentes usam julgamento na informação financeira e na estruturação de operações para alterar relatórios financeiros, buscando enganar interessadas sobre o desempenho da empresa ou de influenciar os resultados contratuais que dependem de saldos contábeis reportados.
}

Segundo Wong (2011), o gerenciamento de resultados pode ser aplicado quando da manipulação operacional ou a contabilidade. A manipulação operacional - também chamada de gerenciamento de resultados reais - afeta o tempo ou a seleção de eventos de negócios reais, além de conceder descontos aos clientes para aumentar as vendas. Aquele autor aponta resultados onde documentou que os administradores aplicam o gerenciamento de resultado para aumentar o lucro reportado quando desviam da meta, em detrimento de conseguir satisfazer os clientes para a obtenção de um bom desempenho de longo prazo.

Para Schipper (1989), o gerenciamento dos resultados representa uma intervenção deliberada no processo de elaboração das demonstrações financeiras, com a intenção de obtenção de benefício, oposto ao processo neutro de reporte dos resultados contábeis. No que concerne à literatura nacional, Martinez (2001) atenta que o gerenciamento dos resultados se dá dentro dos limites que prescreve a legislação contábil, buscando os pontos em que as normas facultam certa discricionariedade ao gestor. 
A manipulação contábil faz uso de acréscimos para gerir lucros, escolhendo certos métodos de contabilidade. Healy (1985, p. 86) define acccruals como "a diferença entre os ganhos reportados e fluxo de caixa das operações".

Conforme Wong (2011), os acréscimos (ou accruals) utilizados para o gerenciamento de resultado incluem depreciações e amortizações, mudanças no capital de giro, perdas extraordinários e alterações na disposição, que precisam de julgamento da administração para valorizá-los.

O gerenciamento de resultado pode ser segregado em modalidades diferenciadas, as quais podem ser assim resumidas: a) Bump Up; b) Cookie-Jar Accounting; c) Income Smoothing; e, d) Big Bath Accounting - que refletem os objetivos e incentivos para a aplicação dos procedimentos de gerenciamento de resultado, de acordo com Burgstahler e Dichev (1997):

- Bump Up: para as empresas que possuem ações em bolsa, os gestores possuem incentivo para fazer com que a meta seja ultrapassada e, nestes casos, as empresas fazem uso de alguma forma de gerenciamento de resultados para melhorar seu desempenho;

- Cookie-Jar Accounting: modalidade onde a instituição, com informações prévias de que os resultados devem ultrapassar um determinado montante esperado, influencia os gestores a reduzir os resultados correntes, para aumentar o resultado quando o mesmo estiver abaixo do esperado;

- Income Smoothing: modalidade mais encontrada nas pesquisas empíricas. A premissa é de que a dispersão dos resultados é entendida pelos usuários como medida de risco. Assim, uma menor variação tende a atrair mais investidores, bem como facilitar a captação de recursos a custos mais baixos. A percepção do mercado pode incentivar os gestores a tornar o resultado menos volátil, suavizando o seu fluxo de crescimento;

- Big Bath Accounting: modalidade de aumento dos resultados futuros pela antecipação de despesas que não precisariam ser reconhecidas no período corrente.

Conforme Dechow e Skinner (2000), a identificação de práticas de suavização de resultados pode ser algo difícil em função do regime de competência apresentar resultados com menos flutuações relativamente ao padrão observado no regime de caixa. Assim, eventualmente, é difícil distinguir a suavização decorrente de práticas de gerenciamento de resultado provenientes da operação natural do regime de competência e do exercício legitimo 
da discricionariedade, que objetivam a apresentação de informações que sejam úteis para os investidores avaliarem o desempenho econômico e a capacidade futura de geração de caixa das empresas.

Segundo Dantas (2012), a prática do gerenciamento de resultados em bancos, com a utilização da provisão para créditos de liquidação duvidosa se dá em decorrência da subjetividade nos julgamentos da administração. Adicionalmente, aquele autor aponta que Sistema Financeiro Nacional (SFN) brasileiro, por exemplo, é previsto que as operações de crédito devem ser classificadas por ordem crescente de risco, com a utilização de critérios consistentes e verificáveis, com base em informações internas e externas; e ainda, que, com o período de vigência da Resolução CMN 2.682/99, as instituições dispõem de histórico de perdas e experiência acumulada que possibilitam, de certo modo, o aprimoramento das estimativas.

Conforme McNichols e Wilson (1988), a discricionariedade nas receitas e despesas em relação a outros instrumentos é relevante. Portanto, constitui um meio eficaz de gerenciamento de resultado em relação a não percepção por parte dos outsiders.

A dificuldade de identificação do gerenciamento de resultado pelos usuários, especificamente naqueles casos que envolvem discricionariedade sobre as estimativas, revelase um estímulo para o emprego dos procedimentos de gerenciamento de resultado. Este é possibilitado por permitir a aplicação de julgamento envolvendo certo grau de subjetividade, nas premissas possíveis para mensuração contábil. Assim, relacionando-se à subjetividade e à flexibilidade no julgamento, é possível identificar que interesses particulares podem ser determinantes no conteúdo das demonstrações financeiras e do resultado apresentado pelas mesmas.

As normas contábeis não abrangem todas as possíveis situações operacionalizadas pelos negócios e, portanto, os padrões contábeis não conseguem limitar a aplicação de estimativas nas escolhas entre diferentes procedimentos alternativos. Assim, têm-se o espaço para o gestor aplicar suas estimativas em aspectos como mensuração com métodos mais favoráveis.

Spohr (2005) afirma que a regulação da Contabilidade orienta e restringe os gestores em seus relatórios financeiros para precisamente melhorar a relevância e a fiabilidade da informação financeira. As principais normas de Contabilidade são estabelecidas e desenvolvidas por organizações independentes, como, por exemplo, o Financial Accounting Standards Board (FASB), nos Estados Unidos da América (EUA), e o International Accounting Standards Board (IASB), na Europa. 
A assimetria de informação se dá quando algumas partes, enquanto em transações comerciais, têm uma vantagem de outras informações (SCOTT, 2003). Para Spohr (2005), a assimetria de informações entre gestores e usuários externos de informação permite que os gerentes façam uso de seu poder discricionário na preparação e divulgação de informações de contabilidade para sua própria vantagem. Aquele autor ainda considera que, embora o oportunismo seja limitado tanto pelas normas de Contabilidade como por auditores independentes, existem provas recentes tanto na literatura acadêmica como na imprensa popular que sugerem que os administradores fazem uso de seu poder discricionário sobre números contábeis para o alcance de ganhos privados. Mais especificamente, o gerenciamento de resultados é uma atividade onde os gestores fazem uso de seu julgamento, conforme Spohr (2005), para enganar as partes interessadas sobre o desempenho econômico da empresa ou de influenciar os resultados contratuais, ideia consistente com Healy e Wahlen (1999).

Segundo Spohr (2005), é difícil identificar se o gerenciamento de resultados tem a propensão de ser enganoso. Os primeiros estudos sobre o tema testaram a conexão entre os incentivos gerenciais e as opções de diferentes métodos de contabilidade. No entanto, para aquele autor, as mudanças de métodos contábeis são relativamente fáceis para a detecção por parte de usuários externos e, portanto, têm sucesso limitado para fins de utilidade, mesmo tendo potencial discricionário.

\subsection{Gerenciamento de resultado em instituições financeiras}

Segundo Cornett, McNutt e Theranian (2009), o estudo do gerenciamento de resultado no sistema financeiro é especialmente delicado, haja vista os impactos que os mais variados tipos de problemas em bancos podem acarretar no comportamento da economia. Cheng, Warfield e Ye (2009) ressaltam que os efeitos da crise aumentam a relevância de se investigar a prática do gerenciamento de resultados no segmento bancário, tendo em vista a relevância dos bancos na economia.

Conforme Cohen et al. (2014), os reguladores bancários visualizam as provisões para perdas com empréstimos no balanço patrimonial, como um tipo de capital que pode ser utilizado para absorver prejuízos. Um equilíbrio maior na provisão para perdas de empréstimo permite ao banco absorver maiores perdas inesperadas. Entretanto, com base nos aspectos discricionários envolvidos, a mensuração da provisão pode representar uma possibilidade de gerenciamento de resultado. 
Em sua pesquisa, Goulart (2007) afirma que uma das bases de um sistema financeiro sólido é a transparência - razão que muitos órgãos internacionais e bancos centrais defendem a adequada evidenciação da situação patrimonial, financeira e de resultados dos bancos. As práticas de gerenciamento de resultados podem representar um comprometimento da divulgação da real situação das instituições financeiras.

As provisões para perdas são, em realidade, as grandes acumulações para os bancos comerciais e, portanto, têm impacto significativo sobre os resultados e para o capital dos bancos (AHMED; TAKEDA; THOMAS, 1999). A finalidade das provisões para perdas de empréstimo é ajustar as estimativas para perdas com empréstimos dos bancos para refletirem as perdas futuras esperadas sobre suas carteiras de empréstimos. Neste sentido, Ahmed (1999) destaca as auditorias realizadas, que confirmam a afirmação. No entanto, os administradores dos bancos também têm incentivos para fazer uso das provisões para perdas para gerir os resultados e o capital regulamentar, bem como para sinalizar sobre as perspectivas futuras.

Ahmed, Takeda e Thomas (1999), relativamente à proposição de suavização dos resultados (income smoothing), testaram algumas hipóteses de gerenciamento de resultado com provisão para crédito de liquidação duvidosa de empréstimos, e concluíram há incentivo de administradores dos bancos em "suavizar ganhos".

Para Cohen et al. (2014), na proporção que o nível de perda de crédito é menor do que as perdas esperadas, a relação de capital do banco (patrimônio líquido em relação a ativos) vai ser aumentada, bem como, sua capacidade de suportar perdas inesperadas. O autor afirma ainda que, ao contrário de provisões para perdas com empréstimos, o resultado com ganhos e perdas são escolhas discricionárias relativamente não regulamentadas e não auditados.

Cohen et al. (2014) afirmam que os bancos utilizam as provisões para perdas com empréstimos para gerir resultado e os níveis de capital. O autor constata ainda que acumulações discricionárias são negativamente relacionadas com o capital, no trabalho cita que os administradores aumentam provisões discricionários para perdas com empréstimos quando eles esperam fluxos de caixa futuros. Entre outros aspectos, constata que os bancos públicos são mais propensos do que os privados a utilizar as provisões para perdas e ganhos e perdas de títulos realizados para eliminar pequenas diminuições de lucros. Um aspecto importante para os bancos é a regulamentação, para eles, há exigência de relação de capital mínimo, buscando impedir que os bancos vão à falência. Quando os bancos estão a atingir baixos índices de capital, há um aumento na vigilância por parte das autoridades e, em casos graves, há intervenções nas operações de bancos com o capital inadequado (BEATTY; CHAMBERLAIN; MAGLIOLO, 1995). 
Conforme Wong (2011), internacionalmente, o Comitê de Supervisão Bancária da Basiléia, por meio do Acordo de Basileia, estabelece critérios para garantir que os bancos tenham patrimônio líquido adequados ao mercado ou ao risco de crédito que o banco se expõe em sua intermediação financeira. Em outras palavras, quanto maior for o risco a que o banco está exposto, mais capital ele precisa para proteger sua solvência e integridade. Para medir a exposição ao risco do seu empréstimo, os bancos utilizam o modelo (VaR) Value-at-Risk. O VaR fornece uma medida única, a medição do risco de possíveis perdas em uma carteira de instrumentos financeiros. A administração dos bancos usa o VaR para medir crédito ou padrão para estimar os riscos de liquidação duvidosa e estabelecendo requisitos de capital. As regras internacionais de Basiléia exigem que os bancos para calculem suas previsões de VaR, nos bancos dos Estados Unidos da América (EUA) é requerido divulgar os riscos de mercado usando VaR ou um modelo alternativo.

A divulgação do VaR possui 03 (três), quais sejam: 1) que ele forneça uma medida resumida do risco de mercado a que o banco esteja exposto; 2) para estimar provisões suficientes para perdas de capital; e, 3) para permitir que o regulador possa avaliar a validade do modelo de VaR (PÉRIGNON; DENG; WANG, 2008).

No entanto, cada banco pode usar seu próprio modelo interno de VaR em vez de uma estrutura de medição padronizada. Não é uma obrigação para os bancos divulgar as especificidades do seu modelo interno de VaR. Isso significa que a administração do banco tem autoridade sobre como definir o modelo e tem a possibilidade de subestimar ou superestimar suas estimativas de VaR para reduzir ou aumentar as provisões para créditos de liquidação duvidosa e exigências de capital, que pode aumentar seus lucros, ou reduzi-los.

O poder discricionário que a gestão do banco possui para estimar o montante das provisões para perdas com empréstimos precisam se enquadrar às diretrizes regulatórias para a imparidade de crédito. O Financial Accounting Standards Board (FASB) fornece normas contábeis para o reconhecimento e mensuração de perdas com empréstimos, assim como o International Accounting Standards Board (IASB). Wong (2011) destaca que, no FAS n. 5, para um empréstimo ruim é reconhecido provisão quando i) "é provável que um ativo ter sido prejudicado" e ii) "o montante da perda pode ser razoavelmente estimado". O autor afirma que pelo FAS n. 114 que um empréstimo está comprometido quando "é provável que um credor não seja capaz de pagar todos os juros e principal quando contratualmente devidos de acordo com os termos do contrato do empréstimo". O IAS 39, determina que deve ser avaliado se existe evidência objetiva de perda no valor recuperável individualmente para 
ativos financeiros que sejam significativos, e individual ou coletivamente para que não sejam individualmente significativos.

Um empréstimo renegociado também é considerado prejudicado e vai ser reclassificado como ativo em curso anormal, sendo este conceito também utilizado pelas estimativas de perdas feitas no Brasil, Portugal e Espanha, onde a Resolução CMN n. 2.682/1999, Aviso n. 03/1995 e Circular n. 04/2004, respectivamente, determinam os aspectos que devem ser observados para a constituição das provisões para perdas. No apêndice é abordado as questões do regulamento contábil aplicável as instituições financeiras brasileiras e luso-espanholas.

O setor bancário possui várias acumulações discricionárias (accruals) que são materialmente significativas e requerem julgamento substancial. A literatura contábil foca frequentemente nas provisões para perdas de empréstimos para detecção de gerenciamento de resultados em bancos. A provisão para perda com empréstimos é um accrual para os bancos, e que tem um impacto significativo sobre os lucros e no capital social. O principal objetivo da provisão para perda é ajustar as estimativas para perdas com empréstimos do banco para refletir futuro esperado de perdas em suas carteiras de empréstimos (AHMED; TAKEDA; THOMAS, 1999). No entanto, os gestores bancários podem ter incentivos para usar as provisões para gerenciar o resultado.

No trabalho de Beaver e Engel (1996) têm-se as quatro motivações para a utilização discricionária das provisões para perdas, quais sejam: 1) regulamentação; 2) relatórios financeiros; 3) fatores fiscais; e, 4) sinalização ao mercado. Além dos benefícios com income smoothig que também é um incentivo para manipular as provisões para perdas (CHENG; WARFIELD; YE, 2009; AHMED; TAKEDA; THOMAS, 1999).

Neste sentido, têm-se que:

- Motivações regulamentares surgem porque os reguladores utilizam as relações de capital para medir os riscos de capital dos bancos e para a identificação e monitoramento de bancos com baixa solvência. Quando a relação de capital se aproxima da exigência de capital mínimo é provável para os bancos passem a gerenciar resultado. Beatty, Chamberlain e Magliolo (1995, p. 233) documentam que ao se aproximar a relação de capital primário de 5,5\% é ruim para os bancos, porque aumenta a chance de escrutínio regulamentar.

- Motivações de relatório financeiro surgem porque contratos são expressos em termos de números contábeis e podem pressionar as provisões para perda, afetando o valor econômico de um banco e seus gestores. 
- Incentivos para fins fiscais surgem porque as despesas tributárias representam um custo significativo para os bancos. Pesquisas concluem que os bancos podem reduzir o valor presente de pagamentos de impostos (BEATTY; CHAMBERLAIN; MAGLIOLO, 1995).

- A sinalização ao mercado ocorre quando um banco 'mais forte' quer distinguir-se dos bancos "mais fracos". As provisões para perdas são usadas para sinalizar informações privadas sobre intenções futuras de ganhos mais elevados aos investidores e ao mercado de ações. Segundo Wong (2011), aumentar as provisões para perdas é considerado um sinal de força.

- Suavização do lucro devido à volatilidade dos lucros. Obter um fluxo suave de lucros reduz a assimetria de informações entre gestores e partes interessadas, reduzindo assim o custo de capital. Em Wong (2011), há referência de que bancos públicos se envolvem mais em gerenciamento de resultados que os bancos privados devido ao maior custo de agência e de uma maior assimetria de informações. Além disso, uma menor volatilidade transmite um sinal de menor risco, diminuindo a visibilidade evitando assim a chance de avaliação potencial dos órgãos reguladores.

Beatty, Ke e Petroni (2002) sugerem que os bancos públicos tendem a obter mais ganhos e menos perdas para transformar pequenas quedas nos lucros em pequenos aumentos de lucros reportados. A realização (venda) de ativos depende da diferença entre o seu valor no balanço patrimonial e seu valor de mercado e, assim, cria uma perda contábil. Embora os órgãos reguladores estejam mais preocupados com o desempenho operacional do que os preços das ações, por si só, eles também devem estar preocupados com dramáticas quedas de preços de ações, na medida em que tais declínios sinalizam deterioração no desempenho futuro.

O gerenciamento de resultados pode aumentar o risco de retornos extremos do mercado de ações, limitando a disponibilidade de informações sobre a empresa. Em Jin e Myers (2006), os administradores usam o seu poder discricionário para impedir o fluxo de informações públicas sobre o desempenho da empresa. Os gerentes normalmente têm incentivos para adiar o lançamento de más notícias, mas em algumas circunstâncias há liberação repentina de informações negativas acumuladas e por consequência há uma queda de preço das ações da empresa. Em um cenário mais geral, mesmo se o gerenciamento de resultados não está estrategicamente sendo explorado pelos gestores, ele ainda pode resultar em interrupção das distribuições de informações para investidores externos. Eventos de 
informação discretos são reflexos nos movimentos substanciais de preços de ações. Isso se confirma para as empresas financeiras, bem como industriais (COHEN et al., 2014).

Segundo o autor, o gerenciamento de resultados em bancos geralmente é medido pela propensão para fazer provisões para perdas com empréstimos ou na realização discricionária de ganhos ou perdas.

Em Ahmed, Takeda, Thomas (1999), é reforçado o impacto financeiro referente às provisões para perdas de empréstimos, onde sugere que as provisões têm grande efeito sobre os lucros dos bancos, assim investiga a relação entre a constituição de provisões em cenários de mudanças econômicas.

Conforme Zendersky (2005), estudos pioneiros com ênfase nas despesas de provisão para créditos de liquidação duvidosa analisaram o componente informacional das despesas com provisão para perda com operações de crédito nos bancos dos Estados Unidos da América. Na pesquisa foi verificada a avaliação de investidores no que diz respeito às variações dos créditos vencidos não pagos, nas despesas de provisão para créditos de liquidação duvidosa e nos créditos baixados como prejuízo nos bancos comerciais.

Ainda conforme o autor, pesquisas apresentaram evidências de relação positiva entre as despesas de provisão para créditos de liquidação duvidosa constituídas pelos bancos e o retorno de suas ações. Os estudos consideravam que o mercado interpretava a constituição das provisões como evidência de informações sobre a expectativa da administração em relação aos resultados futuros. No estudo considerou como variáveis explicativas: i) a variação dos créditos vencidos e não pagos; ii) categorias de empréstimos; iii) variação dos créditos vencidos e não pagos, explicando a variação dos créditos vencidos e não pagos (ZENDERSKY, 2005). O segundo modelo para explicar as despesas com provisão para crédito de liquidação duvidosa foi utilizado como variável: i) saldo no início do período das categorias de operações de crédito; ii) variação esperada dos créditos vencidos e não pagos que é o resultado da variação dos créditos vencidos e não pagos do primeiro modelo; iii) os créditos vencidos e não pagos e iv) provisão para créditos de liquidação duvidosa (conta retificadora do ativo).

A pesquisa de Beatty, Chamberlain e Magliolo (1995) abordou o comportamento discricionário dos gestores em relação a determinadas acumulações discricionárias com a finalidade de obter metas. A pesquisa comtemplou o período de alteração da regulamentação sobre o capital mínimo regulatório, ocorrida em 1989. O trabalho verificou se as instituições financeiras alteravam o momento de reconhecimento, despesas com provisão para crédito de liquidação de liquidação duvidosa, baixa para prejuízo, resultado com depósitos e outros com 
propósito gerenciar o capital regulatório, resultado e obrigações tributárias decorrentes do resultado.

O estudo daqueles autores ainda apontou que as decisões de gerenciamento de capital, resultados e obrigações tributárias podem ocorrer no mesmo momento. A pesquisa na verificação de accruals no gerenciamento de resultado de forma concomitante, foi utilizado cinco modelos semelhantes, tendo cada um, acumulações relativas ao gerenciamento de resultado avaliado. No modelo que avalia gerenciamento de resultado por meio das provisões para crédito de liquidação duvidosa utilizaram como variáveis dependentes: i) créditos baixados como prejuízo; ii) outros ganhos ou perdas; iii) ganhos com depósitos de planos de pensão; iv) títulos; v) resultado antes dos impostos; vi) capital regulatório antes de nível um e vii) componente não discricionário da provisão.

Como resultado da pesquisa, Beatty, Chamberlain e Magliolo (1995) obtiveram evidências do uso das provisões para crédito créditos de liquidação duvidosa, dos créditos baixados como prejuízo para gerenciar o capital regulatório.

O estudo de Beaver e Engel (1996) encontra evidências que sugerem que os investidores interpretavam as acumulações discricionárias das despesas de provisão para crédito de liquidação duvidosa como forma de resiliência, tendo em vista que os resultados se mostravam suficiente para absorver as despesas. Na pesquisa supramencionada, aqueles autores calcularam o componente não discricionário e um primeiro estágio de um modelo, como variáveis explicativas utilizou: i) o total da carteira de crédito; ii) créditos vencidos e não pagos; iii) variação dos créditos vencidos e não pagos previstos, e em um segundo modelo calcularam o componente discricionário da provisão para créditos de liquidação duvidosa pela diferença entre o total da provisão e o componente não discricionário. Como resultado os pesquisadores concluem que os créditos vencidos e não pagos, a carteira de operações de crédito e os créditos baixados explicam a parcela não discricionária da provisão para créditos de liquidação duvidosa, além do componente não discricionário da provisão para créditos de liquidação duvidosa é negativamente precificado pelo mercado e os créditos vencidos e não pagos dão informações adicionais sobre a diminuição do potencial econômico das operações de crédito.

Ahmed, Takeda e Thomas (1999) realizaram uma pesquisa sobre utilização das despesas de provisão para crédito de liquidação duvidosa como forma de gerenciar o capital regulatório e resultados, analisou as instituições financeiras entre o período de transição da regulamentação sobre do capital regulatório. $\mathrm{Na}$ pesquisa utilizou modelo com as despesas com provisão para crédito de liquidação duvidosa como variável dependente e como 
explicativas: i) variação dos desvios do ativo; ii) variação das dívidas de negócios falidos; iii) variação dos créditos vencidos e não pagos; iv) resultado antes do imposto de renda e despesas de provisão para crédito de liquidação duvidosa e v) variável dummy para identificar o capital entre os regimes de regulação anterior do atualizado naquele momento.

Os resultados de Ahmed, Takeda e Thomas (1999) confirmaram a hipótese de gerenciamento de capital e refutaram a hipótese de gerenciamento de resultados. A variável resultado antes do imposto de renda e despesa de provisão para créditos de liquidação duvidosa tiveram relação positiva, mas não foram significativas com as despesas com provisão para crédito de liquidação duvidosa na regulamentação anterior e negativa na atualizada, naquele momento. A pesquisa encontrou relação positiva entre a qualidade dos créditos e as despesas com provisão para crédito de liquidação duvidosa.

O estudo de Shrieves e Dahl (2003) avaliou a utilização de discricionariedade contábil nas instituições financeiras do Japão. A análise contemplou o período entre 1989 e 1996 . O primeiro ano do estudo foi o início da vigência do Acordo da Basiléia que, conforme os autores, ameaçou reduzir o acesso dos bancos japoneses ao mercado internacional em decorrência da deterioração da qualidade de seus ativos. A pesquisa abordou a hipótese de que bancos japoneses utilizaram práticas de gerenciamento de resultados como forma de reagir ao cenário adverso.

O modelo elaborado por Shrieves e Dahl (2003) analisou a relação entre as despesas de provisão para créditos de liquidação duvidosa, variável dependente com as variáveis explicativas: i) retorno não discricionário sobre os ativos (razão pelo ativo total do resultado antes dos tributos, itens extraordinários ganhos ou perdas com títulos e valores mobiliários e despesas com provisão para crédito de liquidação duvidosa); ii) ganhos ou perdas com títulos e valores mobiliários; iii) dividendos líquidos; iv) saldo da provisão para crédito de liquidação duvidosa no início do período; v) logaritmo natural dos ativos totais; vi) variação da carteira de operações de crédito; vii) variável dummy para diferenciar os bancos de grandes localidades para os regionais; viii) variável dummy pelo produto do ROI entre as instituições financeiras; ix) variáveis binárias para segregar os bancos em quartis de acordo com o nível de capital regulatório em três níveis e x) variação no preço dos imóveis como medida das garantias das operações de crédito.

Os resultados de Shrieves e Dahl (2003) foram de que as instituições financeiras no Japão utilizaram a discricionariedade como meio para atingir objetivos no gerenciamento de resultados, adicionalmente que as instituições com menores níveis de capital regulatório utilizaram os procedimentos como forma de gerenciar o capital. Ainda como resultado, as 
despesas com provisão para créditos de liquidação duvidosa estavam positivamente relacionadas com os resultados, os ganhos ou perdas com títulos e valores mobiliários tiveram relação negativa, demonstrando a utilização complementar.

A pesquisa realizada por Pinho e Martins (2009) avaliou o comportamento discricionário na provisão para crédito de liquidação duvidosa nos bancos portugueses, objetivou avaliar o impacto do ambiente regulatório das instituições financeiras nas práticas de provisionamento discricionário. Na pesquisa desenvolveram um modelo que estrutura a dinâmica da política de provisão para as duas classes de provisões: provisões genéricas e disposições específicas. O modelo é testado usando um banco de dados abrangente de todas as instituições financeiras a operar em Portugal entre 1990 a 2000. O trabalho foi desenvolvido enquanto um dos autores atuava no Banco de Portugal, entidade reguladora das instituições financeiras portuguesas. Os autores afirmam que o banco de dados usado na pesquisa é único e compreendeu bancos sujeitos às regras portuguesas, bem como subsidiárias bancárias sujeitas à sua regulação pelo país de origem, afirmam que conseguiram identificar comportamentos distintos entre eles. Os resultados mostram a importância de tratar os dois tipos de disposições separadamente e apoiam a hipótese de que os bancos têm um comportamento discricionário na criação de suas provisões, e encontraram evidências de alisamento de resultados e gestão de capital.

Os autores encontram também impactos no regime regulatório sobre as políticas discricionárias de provisionamento, isso, conforme os autores, os bancos quando forçados a aumentar um tipo de disposição reagem reduzindo o componente facultativo de outra, uma constatação de substituição para equilibrar os efeitos.

Pinho e Martins (2009), na construção do modelo, relacionam os requisitos regulamentares e o seu impacto nas provisões registradas pelas instituições financeiras, bem como foram especificadas as relações contábeis relevantes incorporadas ao modelo. A dinâmica do estoque de provisões, foi estabelecida no modelo tendo como variável dependente a provisão, sendo explicada: i) pela provisão defasada; ii) provisão para créditos de liquidação duvidosa despesa (o fluxo); iii) o estoque de provisões revertidas devido a recuperações de crédito e iv) o estoque operações baixadas como prejuízo.

A equação de Pinho e Martins (2009) descreve a dinâmica de incentivos às provisões para crédito de liquidação duvidosa, onde o montante é afetado por adições de novos empréstimos e inadimplências, que têm um impacto direto sobre estoque de provisões por meio das despesas. Adicionalmente, um empréstimo baixado implica em uma redução do estoque de provisões. Da mesma forma, uma reversão implica em uma redução do estoque 
das provisões através da redução correspondendo ao valor das disposições diretamente relacionadas com o empréstimo recuperado. Os autores ainda constroem outros modelos, tendo como variável dependente despesa com provisão para crédito de liquidação duvidosa, que é explicada por: i) variação dos créditos vencidos; ii) variação da carteira de crédito; iii) duração média do padrão dos empréstimos inadimplentes do banco; iv) variável corresponde à cobertura total das garantias sobre a carteira de crédito emitido pelo banco no final do período, (medido como a proporção de garantia recebida dividido pela quantidade de empréstimos em aberto); v) provisões revertidas; vi) provisões baixadas pelo prejuízo com as operações de crédito; vii) estoque de provisão para crédito de liquidação duvidosa defasadas; viii) lucro antes dos impostos e provisões e ix) medida de capital primário que foi definido como a soma do patrimônio líquido e dívida subordinada, adicionalmente foram incluídas variáveis dummy na identificação dos períodos da amostra.

Segundo Pinho e Martins (2009), os resultados indicaram que os bancos reagiram com baixo provisionamento considerando os requisitos do período 1990-1994, reduzindo a discricionariedade para provisões genéricas cada vez que eles tinham que aumentar as provisões específicas. Os autores designaram essa prática como um efeito de substituição entre as provisões específicas e genéricas. A pesquisa afirma que nem todos os bancos foram influenciados pela mudança nas necessidades de provisionamento de 1995, como nem todos os bancos que operam em Portugal estavam sujeitos aos mesmos regulamentos. Os autores observaram comportamentos distintos entre bancos nacionais e estrangeiros.

Os bancos estrangeiros tiveram impacto na mudança no total de empréstimos no nível de provisões específicas foi negativa, mas não significativa, sugerindo que não há nenhum efeito de substituição como para os bancos estrangeiros. O resultado é contrastante com o que é encontrada para os bancos domésticos. Os resultados apresentaram provas de um efeito de substituição entre as disposições gerais e específicas para os bancos domésticos. Também encontraram fortes evidências de que esses bancos utilizam os dois tipos de disposições para suavizar o nível de lucros divulgados. Para os bancos estrangeiros é obtida evidencia de suavização para as provisões genéricas.

Pinho e Martins (2009) observaram que os níveis de recuperações explicaram significativamente o nível de provisões para os bancos nacionais, enquanto ele não é relevante para os estrangeiros. Os resultados mostraram uma relação negativa entre o capital e os níveis de provisionamento, que é, resultado consistente com outras pesquisas. Os autores encontraram evidências de gerenciamento de capital para as provisões específicas. No entanto, o coeficiente é negativo, o que significa que bancos com capital inferior têm 
incentivos de provisionamento mais altas, um fato difícil de explicar sob o ambiente regulatório português, segundo os autores.

As mudanças nas exigências regulatórias no período analisado por Pinho Martins (2009) causaram modificações na política de provisionamento nos bancos portugueses. Antes de 1995, observava-se um efeito negativo significativo para a mudança de empréstimos vencidos e não pagos no nível de provisões genéricas e um efeito negativo moderado na mudança de empréstimos no nível de provisões específicas. Ambos os resultados sugerem que o regime de altos provisionamentos do período 1990-1994 pode ter induzido bancos nacionais de recorrer ao efeito de substituição entre as disposições genéricas e específicas. Este resultado não se sustenta para o período 1995-2000 analisado pelos autores.

Pinho e Martins (2009) estudaram os determinantes de provisões genéricas e específicas no setor bancário português, além de desenvolver um modelo estrutural que explica a relação entre estoques e fluxos de provisões, os requisitos regulamentares para incentivos e os determinantes do provisionamento discricionário para as duas classes de provisões. O modelo usou um painel abrangente de todas as instituições financeiras a operar em Portugal entre 1990 e 2000. Foram encontradas diferenças na política de provisionamento entre os bancos nacionais e estrangeiros, que associaram com os ambientes dos diferentes países. Em particular, esta separação, incomum na literatura, revela algum comportamento arbitrário que não se verifica quando os dois tipos de disposições foram tomados como um todo.

A pesquisa identificou que as provisões específicas são determinadas principalmente pela quantidade de empréstimos vencidos e não pagos, baixas para perda e recuperações, sendo esses resultados esperados. As recuperações, correspondem aos ajustes no estoque de empréstimos em inadimplência. Os parâmetros associados às baixas e recuperações diferem do que se esperava do modelo que descreve os requisitos regulamentares essas, indicando assim um comportamento discricionário em políticas de provisionamento, segundo os autores. A conclusão é reforçada pelo suporte de alisamento de resultados e gestão de capital hipóteses para os dois grupos de bancos. A pesquisa, como esperado, encontra evidencias que as provisões genéricas são explicadas principalmente pela quantidade de empréstimos pendentes. Para esse tipo a suavização é detectada em ambos os grupos de bancos, enquanto as práticas de gestão de capital também são encontradas para os bancos estrangeiros.

As diferenças de comportamento entre os dois tipos de bancos refletem essencialmente, segundo Pinho e Martins (2009), nas consequências de regras mais restritivas de Portugal. Neste sentido, aqueles autores afirmam que antes de 1995, os bancos nacionais 
pareciam ter um comportamento mais discricionário do que em 2009, em resposta às regras ainda mais rigorosas. Os resultados sugerem que os bancos não regulamentados no mercado português também reagiram ao aumento das necessidades de provisionamento genéricos baixando seu componente discricionário cada vez que teve de reforçar as disposições específicas, no que chamou de "efeito de substituição" entre os dois tipos de disposições.

O trabalho de Pinho e Martins (2009) estudou as determinantes de provisões genéricas e específicas no setor bancário Português. O modelo estrutural desenvolvido explica a relação entre estoques e fluxos de provisões, os requisitos regulamentares para subsídios e os determinantes do provisionamento discricionário para as duas classes de provisões. Os autores testaram o modelo usando um painel abrangente de todas as instituições financeiras a operar em Portugal entre 1990 e 2000. Os resultados indicaram a existência de gerenciamento por meio da utilização do componente discricionário nas provisões compensado o total das provisões quando havia a necessidade de aumento das provisões por requisitos regulatórios.

Em seu estudo, Goulart (2007) buscou analisar se os bancos apresentam particular interesse na suavização dos resultados, que fomenta a indicação de constância de lucros e diminuição dos riscos pela menor volatilidade dos resultados. Teve como questão da pesquisa se há evidências de que as instituições financeiras utilizam a contabilização de operações de crédito, TVM e derivativos como instrumento de gerenciamento de resultado, tendo em vista a suavização dos resultados divulgados.

O trabalho daquele autor testou as hipóteses de utilização de diferentes contas (contábeis), por parte dos bancos, com vistas ao alisamento de resultados. As rubricas analisadas foram: provisão para créditos de liquidação duvidosa, ajustes a valor de mercado de títulos e valores mobiliários e resultado com derivativos.

$\mathrm{Na}$ pesquisa empírica, foram avaliados dados contábeis semestrais das 50 maiores instituições financeiras em atuação no Sistema Financeiro Nacional do Brasil, no período de junho de 2002 a dezembro de 2006. Foram empregadas as técnicas estatísticas de correlação e regressão, tendo em vista identificar a possível utilização da provisão para crédito de liquidação duvidosa das operações de crédito.

Nos modelos de regressão adotados, consta, como variável dependente, a despesa com provisão para créditos de liquidação duvidosa. O resultado contábil (lucro ou prejuízo líquido), expurgando-se deste o resultado relativo à variável dependente, é utilizado como variável explicativa. A formulação, conforme o autor, é testar a relação entre itens de resultado em uma modalidade operacional (crédito) e o lucro líquido expurgado do efeito da variável dependente. 
Os resultados confirmam o gerenciamento de resultado e a suavização de resultados revelou-se mais forte no caso de operações de crédito, por meio da provisão para créditos de liquidação duvidosa, assim constatou-se que a provisão para créditos de liquidação duvidosa é o instrumento mais contundente em termos de suavização de lucros bancários, seguido pelos derivativos; os ajustes a valor de mercado de títulos e valores mobiliários também favorecem a suavização de resultados contábeis, mas desempenham papel menos relevante, não contribuindo de forma tão significativa como a provisão para créditos de liquidação duvidosa e o resultado com derivativos.

\subsection{Procedimentos de gerenciamento de resultado}

Martinez (2001) encontrou evidências que as companhias abertas brasileiras utilizam o gerenciamento de resultado, e, que apresentam como motivações: evitar reportar perdas, sustentar o desempenho recente, reduzir variabilidade dos resultados. Adicionalmente, que o gerenciamento de resultado contábil é caracterizado como escolhas discricionárias à disposição dos gerentes pelas normas contábeis.

O gerenciamento de resultados, quando utilizado para influenciar o valor da empresa, pode ser, segundo Spohr (2005), dividido em 03 (três) grupos, a saber: 1) estudos onde há conexão entre o gerenciamento de resultados e as principais transações financeiras, incluindo os estudos onde se examinam a ocorrência de gerenciamento de resultado em momento específico, como antes de oferta de ações; 2) pesquisas onde se investiga se os administradores fazem uso do gerenciamento de resultados em um esforço para manipular o preço das ações para aumentar a remuneração baseada em ações; e, 3) estudo onde o gerenciamento de resultados se dá de forma continuada em certa medida nos mercados financeiros, onde existem expectativas de analistas ou a perspectiva de suavizar resultados ou fluxo de caixa ao longo do tempo.

Um volume elevado de transações financeiras tem influência no valor das ações das empresas, que são importantes tanto para os investidores de mercado quanto para os proprietários da empresa. Tais operações, conforme Sphor (2005), exercem pressão sobre o desempenho - aspecto que levou pesquisadores a avaliarem a hipótese de gerenciamento de resultado nessas circunstâncias.

As motivações para gerenciamento de resultado derivadas de aspectos contratuais constituem uma motivação relevante para o gerenciamento de resultado. Um exemplo de contrato que motiva e torna a possibilidade de gerenciamento de resultado mais factível de ser 
realizada, são as cláusulas restritivas, ou covenant, que, conforme Sphor (2005), são cláusulas escritas em termos de números contábeis que podem exigir que o mutuário mantenha um nível mínimo de capital ou ativos fixos, existem fundos que possuem restrições que exigem montante mínimo de lucro líquido.

Em seu estudo, Healy (1985) evidenciou que as políticas de accruals da Administração estão ligadas as receitas vinculadas aos contratos de bônus dos gestores. $\mathrm{O}$ autor observa ainda que os gestores tendem a gerenciar ganhos superiores se os mesmos estão entre o limite inferior que funciona como gatilho do bônus e o limite do bônus de meta. Caso contrário os gestores diminuem o nível de gerenciamento de resultado.

Conforme Mendes e Rodrigues (2006), o Earnings Management observa com frequência com o escopo de "alisar" o resultado o qual é concebido por meio da utilização das discricionariedades existentes nos princípios contábeis geralmente aceitos, visando atingir um crescimento regular e sustentado dos resultados.

Os principais motivos para gerenciamento de resultado, conforme Santos e Grateron (2003), residem em aspectos sociais e características das normas, conforme se segue:

1) Características dos princípios e normas contábeis:

- Existência de múltiplas estimativas;

- Flexibilidade, arbitrariedade e subjetividade na aplicação;

- Interpretações diferentes, porém, válidas dos princípios e normas contábeis;

- Conceito-base de imagem fidedigna pouco claro ou indeterminado; e

- Cuidados da administração na aplicação de princípios como prudência, confrontação de receitas e despesas e uniformidade.

2) Características sociais e de comportamento humano:

- Valores éticos e culturais; e

- Atitude do administrador diante da fraude.

O gerenciamento dos resultados contábeis é uma expressão utilizada para designar um conjunto de práticas adotadas por gestores e contadores com intuito de obter os resultados contábeis desejados, os quais, normalmente, decorrem de manipulações que estão dentro dos limites legais (RODRIGUES, 2007). Consideram que o gerenciamento de resultados "implica em alteração do resultado financeiro empregando escolhas contábeis, estimativas e outras práticas permitidas pela regulação contábil” (AMAT; GOWTHORPE, 2004). 
É demonstrado, na sequência, os aspectos inerentes às práticas que configuram gerenciamento de resultado.

Quadro 1 - Decisões de gerenciamento de resultado.

\begin{tabular}{|c|c|}
\hline Decisões Contábeis "Puras" & Decisões com Impacto no Fluxo de Caixa \\
\hline \multicolumn{2}{|c|}{ "Gerenciamento" dos Resultados } \\
\hline De acordo com as Normas/Princípios Contábeis & Práticas Aceitáveis \\
\hline Contabilidade "Conservadora" & Visando Reduzir Fluxo de Caixa Líquido \\
\hline Reconhecimento muito elevado de provisões; & Retardar Vendas; \\
\hline \multirow{2}{*}{$\begin{array}{l}\text { Aceleração das despesas de depreciação; } \\
\text { Reconhecimento de receitas apenas quando da } \\
\text { cobrança. }\end{array}$} & Acelerar gastos associados a propaganda $\mathrm{e}$ \\
\hline & $\begin{array}{l}\text { publicidade, treinamento e P\&D. } \\
\text { Aumentar Despesas de natureza não-operacional } \\
\text { (Banquetes, Bingos, Doações); }\end{array}$ \\
\hline \multirow{4}{*}{$\begin{array}{l}\text { Contabilidade “Agressiva” } \\
\text { Evitar ou reduzir o reconhecimento de provisões; } \\
\text { Reduzir as cotas de depreciação e amortização; } \\
\text { Reconhecimento de receitas durante produção. }\end{array}$} & \\
\hline & Visando aumentar Fluxo de Caixa Líquido \\
\hline & $\begin{array}{l}\text { Adiar a realização de despesas necessárias de } \\
\text { propaganda \& publicidade treinamento ou P\&D; }\end{array}$ \\
\hline & $\begin{array}{c}\text { Aumentar Receitas não operacionais pela venda de } \\
\text { Ativos da empresa. }\end{array}$ \\
\hline \multicolumn{2}{|c|}{ Contabilidade Fraudulenta e Práticas Inaceitáveis } \\
\hline \multirow{3}{*}{$\begin{array}{c}\text { Que violam as Normas/Princípios Contábeis } \\
\text { Registrar vendas fictícias; } \\
\text { Antecipar (documentalmente) a data de realização das } \\
\text { vendas; }\end{array}$} & \multirow{4}{*}{$\begin{array}{l}\text { Receber e não efetuar a entrega do produto; } \\
\text { Não cumprir com os compromissos financeiros; } \\
\text { Não pagar tributos lançados. }\end{array}$} \\
\hline & \\
\hline & \\
\hline $\begin{array}{c}\text { Superestimar o estoque pelo registro de inventário } \\
\text { fictício. }\end{array}$ & \\
\hline
\end{tabular}

Fonte: Adaptado de Dechow e Skiner (2000).

É possível identificar níveis na aplicação dos procedimentos de gerenciamento de resultado. Ao ultrapassar o limite da aplicação do julgamento os procedimentos passam a se caracterizar como fraudes, por basear-se em procedimentos que estão além da aplicação de estimativas. 
Na revisão da literatura é possível observar que o gerenciamento de resultado deriva de interpretações na aplicação das estimativas e práticas contábeis, possibilitando oportunidades para apresentação de resultados favoráveis utilizando determinadas estimativas convergentes com objetivos da administração.

O gerenciamento de resultado é possível em função da contabilidade exigir julgamento nas premissas utilizadas para mensuração. Um dos primeiros estudos que se relacionavam com gerenciamento de resultados, conforme Zendersky (2005), foram publicados no início da década de 1950, que se concentravam, principalmente, no objetivo minimizar as variações dos lucros. O estudo, segundo aquele autor, se destaca, pois demonstra que os órgãos regulamentadores se mostram voltados aos princípios, tendo em vista a preocupação com a manipulação de resultados.

O componente discricionário de provisões para perdas com empréstimos como proxy para o gerenciamento de resultados em bancos foi estimado por Beaver e Engel (1996). Seus resultados indicam que os administradores de bancos com incentivos elevados de capital não são positivamente relacionados com o gerenciamento de resultados. Mas, quando a relação de capital é baixa e a possibilidade de intervenção regulatória é alta, os gestores com elevados incentivos de capital são positivamente associados com o gerenciamento de resultados ascendentes.

Cheng, Warfield e Ye (2009) examinaram o efeito da relação de capital mínimo em gerenciamento de resultados no setor bancário, utilizando 712 observações no período 19942007. Eles argumentam que o potencial de intervenção regulamentar pode influenciar os incentivos de gerenciamento de resultados. Quando há possibilidade de reguladores intervirem quando a relação de capital está próxima do mínimo, é provável que o que os administradores utilizem de gerenciamento de resultados para evitar a intervenção regulamentar (WONG, 2011).

A principal motivação por trás de gerenciamento de resultados é alcançar um resultado desejado em um período, em vez de apresentar com precisão o valor dos ativos e passivos ou os resultados das operações (WONG, 2011).

As pesquisas realizadas por Healy (1985) avaliam manipulações contábeis decorrentes de plano de bônus aos administradores, onde avalia a influência das escolhas contábeis em função dessa motivação. Em seu estudo, DeAngelo (1986) discute os aspectos inerentes a manipulação de resultado considerando o incentivo dos administradores que possuem ações da Companhia, assim reconhece que a manipulação é possível porque os princípios contábeis permitem aos gestores a escolha dos procedimentos a serem adotados. Isso em função dos 
princípios contábeis não conseguirem comtemplar a totalidade das situações possíveis devido à amplitude e complexidade das operações transacionadas. O estudo de Healy (1985) sugere que os gestores gerenciam ganhos para aumentar seus bônus, esse estudo o primeiro a testar incentivos da administração por meio de accruals.

Dechow et al. (2012) apresentam uma nova abordagem para testar gerenciamento de resultados entre exercícios: a abordagem explora a propriedade inerente a contabilidade de que em um exercício, qualquer gerenciamento de resultado baseado em accruals deve ser revertido em outro período. Os resultados indicaram que a metodologia pode resolver problemas relacionados a omissão de variáveis. Gerakos (2012) afirma a existência de fragilidade na abordagem de gerenciamento de resultado em pesquisas sobre o tema.

No Brasil, o estudo de Martinez (2001) foi o primeiro a discutir gerenciamento de resultados. Aquele autor implementou um modelo de regressão múltipla, para estimar as acumulações discricionárias das companhias abertas não financeiras e testou diversas hipóteses (GABRIEL; CORRAR, 2010). Ainda conforme aquele autor, existiam outros trabalhos envolvendo empresas não financeiras no Brasil, dos quais se destacam: Fuji (2004), Zendersky (2005), Xavier (2007) e Galdi e Pereira (2007).

Fuji (2004) teve como abordagem a utilização de gráficos de distribuição de frequências, dos coeficientes de correlação de Pearson e do modelo de acumulações discricionárias desenvolvido por Jones (1991) (GABRIEL; CORRAR, 2010). Ainda conforme Gabiel e Corrar (2010), o modelo considerou os resíduos da regressão de acumulações totais em relação a mudanças nas operações de créditos e ativo total, de forma a mensurar as acumulações discricionárias. Fuji também constatou a utilização da provisão para créditos de liquidação duvidosa com a finalidade de suavização de resultados.

Em seu trabalho, Zendersky (2005) fez uso da abordagem sobre as acumulações discricionárias combinada com a metodologia de estimação em dois estágios.

O trabalho de Gabriel e Corrar (2010) fez uso do estudo de Xavier (2007), observando a base de dados restritos à supervisão bancária para cálculo da parcela discricionária da provisão para créditos de liquidação duvidosa.

Galdi e Pereira (2007), por meio da análise de dados em painel, concluíram que a contabilização de derivativos não indica a utilização de suavização de resultados e/ou de big bath accounting pelos bancos brasileiros.

Dantas et al. (2013) e Dantas, Medeiros e Lustosa (2013) estruturaram um modelo de dois estágios que identifica parcela de discricionariedade no resultado com títulos e valores mobiliários, conseguindo identificar gerenciamento de resultado por meio do modelo, no 
segundo estudo aborda operações de crédito por meio de modelo econométrico de dois estágios, onde consegue obter melhora na identificação de discricionariedade relativamente as operações de crédito.

Healy (1985) examinou se os administradores manipulam o lucro de forma a aumentar a sua remuneração na forma de bônus. Na pesquisa, avaliou a existência de gerenciamento de resultados contábeis pela comparação dos valores das acumulações (accruals), com o seu valor médio no tempo. Como resultado observou associação entre o valor das acumulações e os incentivos dos gestores para reportar aumento no resultado.

Em Jones (1991), fez-se um exame sobre o fato de se as firmas se beneficiam de proteção alfandegária como aumento de tarifas e redução das quotas, e se tentam reduzir os lucros adotando práticas de gerenciamento dos resultados contábeis. Em sua pesquisa, aquele autor utilizou resíduos da regressão dos accruals totais em relação às mudanças nas receitas e do ativo permanente, como meio de mensurar as acumulações discricionárias. Os resultados não rejeitaram a hipótese de que os gestores efetuam práticas para reduzir os lucros nos períodos em que estão sendo investigados.

Burgstahler e Dichev (1997) obtiveram evidências de que as empresas gerenciam seus resultados para evitar perdas e para sustentar resultados. Utiliza histogramas da distribuição e da variação de lucros entre empresas, para proporcionar evidências da existência de gerenciamento dos resultados contábeis. Como resultado, identificaram uma incomum distribuição frequência de pequenos lucros.

De forma geral, as pesquisas corroboram a existência de gerenciamento de resultado, com resultados importantes nas pesquisas realizadas, além de alguma diversidade na forma de abordar o tema. 


\section{METODOLOGIA}

Os estudos sobre gerenciamento de resultados de forma geral abordam o problema por meio de análises do fluxo de caixa e análise de accruals. Conforme Beneish (2001), a partir da década de 1980 os estudos sobre gerenciamento de resultado concentraram-se nos accruals, um dos motivos seriam as estimativas possibilitadas pelas práticas contábeis, o autor considera mais provável gerenciamento de resultado por meio de acruals.

Os estudos de gerenciamento de resultados em instituições financeiras têm maior concentração na análise nas despesas com provisão para créditos de liquidação duvidosa, fato esse que se justifica por ser a maior estimativa nas instituições financeiras. Kanagaretnam, Lobo e Mathieu (2001) afirmaram que, em geral, as despesas de provisão para créditos e liquidação duvidosa são os maiores accruals dos bancos e, dessa forma, são meios relevantes para gerenciamento de resultados.

A pesquisa aborda gerenciamento de resultado por meio da análise de acruals. Considerando que as despesas com provisões para créditos de liquidação duvidosa (LLP em inglês Loan Loss Provisions) é a principal estimativa e acumulação discricionária dos bancos é uma premissa relevante para avaliação de gerenciamento de resultado em bancos. Para estruturação do modelo foram considerados os aspectos constantes nas pesquisas sobre o tema. Kanagaretnam, Lobo e Mathieu (2001), a respeito de provisão para perda e suavização de resultados em bancos, observaram que a preocupação dos gestores com a manutenção do emprego cria um incentivo para que estes suavizem resultados. Na pesquisa, aqueles autores

perceberam que bancos com desempenho corrente ruim e bancos com expectativa de bom desempenho futuro "emprestaram" resultados de períodos futuros, reduzindo provisão corrente. Para os bancos com bom desempenho corrente e expectativa de desempenho futuro ruim, houve prática de postergar lucros para períodos futuros, por meio do aumento da provisão para perda e consequente redução do lucro corrente.

A provisão para créditos de liquidação duvidosa de operações de créditos é a principal acumulação discricionária das instituições financeiras, que nos bancos é a principal alocação dos recursos. Nesse sentido, as operações de créditos podem ser consideradas como a principal modalidade de aplicação dos recursos bancários. Para Beaver e Engel (1996), a provisão para perda é o principal accrual do setor bancário. Segundo Kanagaretnam, Lobo e Mathieu (2001), trata-se, para a maioria dos bancos, do maior accrual, sendo significante na suavização de resultados. 
Em sua pesquisa, Shrieves e Dahl (2003), com uma amostra de 607 observações e período de análise de 1989 a 1996, observaram que os bancos japoneses definem a provisão para perdas de maneira a suavizar os resultados.

Assim a avaliação de gerenciamento de resultado nos sistemas financeiros brasileiro e luso-espanhol é oportuna por meio da avaliação das estimativas de perdas para operações de créditos considerando evidências obtidas em outras pesquisas, além de ser a grande alocação dos recursos dos bancos.

Estudos que avaliariam o uso das provisões para perdas no gerenciamento de resultados nos bancos apresentam exemplos dos dois tipos de procedimento e a escolha do procedimento depende dos objetivos dos pesquisadores em cada pesquisa em particular. Ahmed, Takeda e Thomas (1999), Shrieves e Dahl (2011) e Goulart (2007), por exemplo, adotam modelos de um estágio em suas investigações. Nos trabalhos de Beaver e Engel (1996), Kanagaretnam, Lobo e Mathieu (2001), Zendersky (2005), Marcondes (2008), Cheng, Warfield e Ye (2011) e Dantas et al. (2013), entre outros, adotam os modelos de dois estágios nas pesquisas.

A partir dos aspectos discutidos nas outras seções, bem como dos argumentos elencados as hipóteses da pesquisa são:

- Há relação positiva entre despesas com provisão para créditos de liquidação duvidosa e os resultados das instituições financeiras brasileiras e luso-espanholas; e

- Há gerenciamento de resultados através da conta despesa com provisão para créditos de liquidação duvidosa nas instituições financeiras brasileiras e luso-espanholas.

\subsection{Formulação do modelo para avaliação de gerenciamento de resultado}

O modelo utilizado na pesquisa foi construído a partir de estudos mencionados, a estrutura baseia-se na metodologia de pesquisas de Beaver e Engel (1996), onde é utilizado modelo de dois estágios.

No estudo do comportamento de conjunto de dados das instituições financeiras em determinado período, é considerado as diferenças entre as instituições e as características de cada uma nos períodos da amostra. O estudo utilizando a estrutura de dados em painel possibilita desenvolver a análise levando em consideração as características individuais ao longo do tempo, assim tendo a oportunidade de avaliar os efeitos para toda a amostra dos eventos ao longo do tempo. 
Com objetivo de avaliar a existência de indícios de gerenciamento de resultado nas instituições financeiras brasileiras e luso-espanholas por meio de provisão para créditos de liquidação duvidosa com operações de créditos foi realizada a estimação da parcela discricionária que compõe a provisão.

O modelo de dois estágios, onde as variáveis que explicam o comportamento não discricionário da provisão para perda são estimadas no primeiro estágio. Os resíduos estimados representam a parcela discricionária, usada como variável dependente no segundo estágio, objetivando avaliar a relação com regressores que expliquem a ação oportunista na gestão de resultados.

De forma geral os modelos de dois estágios usados para estimativa da provisão para créditos de liquidação não discricionária incluem como regressores os elementos que representam o volume da carteira de crédito, os empréstimos vencidos e não pagos e as provisões para créditos de liquidação duvidosa.

Os modelos utilizados para estimar a parcela não discricionária da provisão para créditos de liquidação duvidosa são baseados, principalmente, no uso de indicador relativos ao volume da carteira de crédito, operações vencidas e provisões acumuladas para a regressão que explicam a parcela não discricionária das despesas com PCLD.

Para tanto, o modelo proposto (1) objetiva identificar a parcela discricionária passível de gerenciamento de resultado das provisões para perda (LLP):

$$
\begin{aligned}
& L L P_{i, t}=\beta_{0}+\beta_{i}+\beta_{1} \Delta L O A N_{i, t}+\beta_{2} N P L_{i, t-1}+\beta_{3} \Delta N P L_{i, t}+\beta_{4} L L A_{i, t-1}+\beta_{5} I N T_{i, t}+ \\
& \beta_{6} G D P_{t}+\psi_{1}<T Y P_{i, t}>+\varepsilon_{i t}
\end{aligned}
$$

Onde:

$L L P_{i, t}:$ despesas com provisão para créditos de liquidação duvidosa do banco i no período t, escalonado pelo total de ativos;

$\triangle L O A N_{i, t}$ : variação no valor do saldo da carteira de crédito do período t-1 ao período t do banco i, escalonado pelo total de ativos;

$N P L_{i, t-1}$ : saldo dos créditos vencidos e não pagos no período t-1 do banco i, escalonado pelo total de ativos;

$\triangle N P L_{i, t}:$ variação no valor dos empréstimos vencidos e não pagos do período t-1 a t do banco i, escalonado pelo total de ativos; 
$L L A_{i, t-1}$ : saldo acumulado da provisão para créditos de liquidação duvidosa do banco i no período t-1, escalonado pelo total de ativos;

$I N T_{i, t}$ : taxa de juros implícita média da carteira de crédito do banco i no período t, correspondente à razão entre as receitas de operações de créditos e o saldo médio da carteira; $G D P_{t}$ : taxa de variação no Produto Interno Bruto no período t;

$\left\langle T Y P_{i, t}\right\rangle$ : vetor das variáveis de controle que representam as proporções dos créditos o banco i no período $\mathrm{t}$ distribuídas entre o setor público (PUB), setor privado (PRV) e não residentes (NRES), escalonado pelo total de ativos.

Na construção do modelo, a despeito da utilização dos accruals discricionários como proxy para o gerenciamento de resultados, fatores não discricionários não habituais podem influenciar os accruals anormais, conforme Healy (1985) e Bernard e Skinner (1996).

Com o objetivo de mitigar heteroscedasticidade, as variáveis: $\left(L L P_{i, t}\right),\left(\triangle L O A N_{i, t}\right)$, $\left(L L A_{i, t-1}\right),\left(N P L_{i, t-1}\right),\left(\Delta N P L_{i, t}\right)$ e $\left(L L A_{i, t-1}\right)$, são escalonadas pelos ativos totais do início do período, conforme Kanagaretnam, Lim e Lobo (2010).

A inclusão de variáveis relativas ao saldo da carteira de crédito é justificada pela premissa de que quanto mais operações, maior o tamanho da provisão a ser constituída para cobrir perdas. As variáveis foram utilizadas por Marcondes (2008) e Kanagaretnam, Lim e Lobo (2010).

As características das operações que compõem a carteira de crédito no montante da provisão a serem constituídas em cada período passaram a ser contempladas em estudos como de Kanagaretnam, Lim e Lobo (2010). É considerado que diferentes tipos de operações de empréstimos e financiamentos $\left(T Y P_{i, t}\right)$ impactam de forma diferente na provisão.

A variável representativa dos juros médios das operações de crédito $\left(T Y P_{i, t}\right)$ sugerida por Marcondes (2008) como forma de explicar o comportamento não discricionário das provisões, com o raciocínio de que as carteiras com maiores taxas de juros embutem maior risco e, por esse motivo, maior necessidade de provisão. $\mathrm{O}$ autor incorporou a taxa de juros implícita da carteira $\left(I N T_{i, t}\right)$ como variável explicativa da despesa com provisão, sendo prevista uma relação positiva, tendo em vista a premissa de que carteiras com maior taxa de juros espera-se um maior risco, o que deve se refletir em maior constituição de provisão para responder por potenciais perdas. 
O nível de atividade da economia representado pela variável $\left(G D P_{t}\right)$ é justificada, com o argumento de que a constituição da provisão para créditos de liquidação duvidosa deve ser considerada, entre outros aspectos, as condições econômicas do ambiente em que o banco opera, orientação do Federal Financial Institutions Examination Council (FFIEC) (2001).

Consistente com as orientações para a constituição da provisão para perdas previstas na Resolução n. CMN 2.682/1999, na IAS 39 e nas políticas do FFIEC (2001), foi incluído vetores de variáveis para controlar os graus de concentração por tipo de operação ( $T Y P_{i, t}$ ). Kanagaretnam, Lim e Lobo (2010) utilizaram variáveis equivalentes.

Em relação a variáveis independentes, são esperadas relações positivas entre as despesas com provisão para créditos de liquidação duvidosa e a variação no saldo da carteira de crédito, os empréstimos vencidos e não pagos, as variações nos créditos vencidos e não pagos, e o saldo da provisão para créditos de liquidação duvidosa defasada. Esses são os sinais das relações geralmente observadas nos estudos anteriores.

A relação esperada entre as despesas com provisão para créditos de liquidação e variação do valor do saldo da carteira conforme Dantas et al. (2013), pode ser explicada pela suposição lógica e dedutiva de que quanto maior a variação na carteira de crédito de um banco, maior deve ser a provisão para cobertura de eventuais prejuízos. Em relação aos créditos vencidos e não pagos, a premissa adotada é de que existe uma relação direta entre o nível de despesas com provisão e sua variação, tendo em vista que representam os melhores indicadores da carteira de empréstimos e financiamentos.

A relação entre o saldo acumulado da provisão para créditos de liquidação duvidosa e as despesas com provisão para créditos de liquidação duvidosa, conforme Dantas et al. (2013), tem por base a expectativa de que o reconhecimento de prejuízos em potencial acumulados até o período anterior é uma indicação de perda de qualidade da carteira, que exigirá novos ajustes nas despesas no período corrente. As variáveis i) variação no valor do saldo da carteira; ii) saldo de créditos vencidos e não pagos defasados; iii) variação dos créditos vencidos e não pagos e iv) saldo acumulado da provisão para créditos de liquidação duvidosa são variáveis geralmente incluídas nos modelos que buscam explicar as despesas com créditos de liquidação duvidosa nos bancos. Adicionalmente, outras discussões sobre as variáveis são encontradas em Beaver e Engel (1996), Kanagaretnam, Lobo e Mathieu (2001), Zendersky (2005), Marcondes (2008), Cheng, Warfield e Ye (2011) e Dantas et al. (2013). 
Na pesquisa de Marcondes (2008), foi incluída a taxa de juros implícita da carteira de crédito $\left(I N T_{i, t}\right)$ caracterizando-se como uma variável explanatória com um sinal positivo esperado, tendo em vista que as carteiras com maiores taxas de juros contêm um risco implícito maior, que deve ser refletido em um maior nível de despesas com provisões para compensar perdas em potencial. Dantas et al. (2013) fazem uso da variável como à razão entre as receitas de operações de créditos e o saldo médio da carteira. A relação esperada é apoiada pela suposição de que quanto maior o risco associado ao cliente e ao empréstimo específico, maior a taxa de juros cobrada pela instituição financeira e, consequentemente, maior a provisão para eventuais perdas.

Em Dantas et al. (2013), têm-se a variação no nível de atividade econômica, representada pela taxa de variação no Produto Interno Bruto, tendo como explicação de que a constituição das despesas para créditos de liquidação duvidosa deve considerar, entre outros fatores, a situação macroeconômica, não há sinal esperado na relação da variável.

A variável de controle incluída no modelo apresenta características de composição da carteira, sendo variável que representa a proporção dos créditos distribuídos entre o setor público, setor privado e não residentes. Não há sinal esperado na relação da variável.

Os sinais esperados para as primeiras três variáveis são positivos. O aumento na carteira de operações de créditos relaciona-se positivamente com o aumento das despesas de provisão para créditos de liquidação duvidosa. Os níveis de operações vencidas do período anterior, assim como a variação dos créditos vencidos, também estão positivamente relacionados com a constituição da provisão no período, tendo em vista o risco associado a realização dos créditos leva as instituições a constituírem mais provisões para créditos de liquidação duvidosa. Em relação ao saldo acumulado da provisão para créditos de liquidação duvidosa no período anterior o resultado pode ser positivo ou negativo, haja vista a possibilidade de recuperação de créditos.

No modelo (1), é empregado a abordagem de dados em painéis com efeitos fixos individuais e temporais capturando as diferenças individuais e os efeitos relacionados ao período, que influenciam as instituições financeiras da amostra.

\subsection{Análise de gerenciamento de resultado}

O segundo estágio (2) utiliza a parcela discricionária do primeiro estágio para verificar se o componente discricionário das despesas de provisão para créditos de liquidação duvidosa (DPCLDd) é utilizado com a finalidade de gerenciar resultados: 
$D P C L D d_{i, t}=\beta_{0}+\beta_{1} L L a j_{i, t}+\beta_{2} L n A t_{i, t}+\varepsilon_{i t}$

Onde:

$D P C L D d_{i, t}$ : Componente discricionário das despesas de provisão para créditos de liquidação duvidosa, resíduos do modelo de primeiro estágio;

$L \operatorname{Laj}_{i, t}:$ resultado ajustado pelas despesas com provisões, escalonado pelos ativos totais;

$\operatorname{LnAt}_{i, t}$ : logaritmo natural dos ativos totais, variável representativa do porte das instituições financeiras.

Os resíduos do modelo estimado no primeiro estágio (1) são definidos como os componentes discricionários das despesas de provisão para créditos de liquidação duvidosa $\left(D P C L D d_{i, t}\right)$, os quais são utilizados como variável dependente no segundo estágio da análise no modelo (2).

Dado o objetivo da pesquisa de verificar se as instituições financeiras brasileiras e luso-espanholas possuem relação positiva entre despesas com provisão para créditos de liquidação duvidosa e os resultados das instituições financeiras e se há gerenciamento de resultado através dessa relação, foi incluído o resultado ajustado pela provisão para créditos de liquidação duvidosa $\left(L L a j_{i, t}\right)$, como variável explanatória no modelo (2). Os estudos de Beatty, Chamberlain e Magliolo (1995) e Zendersky (2005), que avaliavam o gerenciamento de resultado em bancos por meio do componente discricionário das despesas de provisão, analisaram a relação entre o componente discricionário das despesas de provisão e o resultado antes da tributação e das despesas de provisão. Shrieves e Dahl (2003) utilizaram os resultados antes da tributação, dos itens extraordinários, ganhos com títulos e valores mobiliários e das despesas de provisão para créditos de liquidação duvidosa, escalonados pelo ativo total.

Assim como nos estudos de Shrieves e Dahl (2003) e Zendersky (2005), foi incluído no modelo o logaritmo natural dos ativos totais $\left(\operatorname{LnAt} t_{i, t}\right)$ para verificar se o porte das instituições financeiras influencia o comportamento discricionário das despesas de provisão para créditos de liquidação duvidosa.

A expectativa é que o sinal do resultado líquido ajustado, $\left(L L a j_{i, t}\right)$ seja positivamente relacionado com $\left(D P C L D d_{i, t}\right)$, pois, em um cenário de gerenciamento de resultado, as instituições financeiras reduzem as despesas quando os resultados são baixos e aumentam as despesas quando os resultados são elevados. Não há um sinal esperado para o $\left({\left.\operatorname{Ln} A t_{i, t}\right)}\right.$. 


\subsection{Amostra}

Para composição da amostra foram coletados dados das 30 maiores instituições financeiras brasileiras e 31 instituições financeiras luso-espanholas. Foi aplicado como restrição à amostra: ausência de dados que compõem os modelos econométricos aplicados na pesquisa.

Para a amostra, foram consideradas as 19 instituições financeiras portuguesas, sendo as 13 maiores instituições financeiras portuguesas ligadas a Associação Portuguesa de Bancos em dezembro de 2014, e os Bancos Popular, Deutsche, BPN, BESI, BES e BANIF Invest, entre os mais representativos em total de ativo. E ainda, as 12 maiores instituições financeiras espanholas ligadas a Associação Espanholas de Bancos, em ordem alfabética no Apêndice A.

A amostra do Brasil foi constituída pelos 30 maiores bancos do país conforme o relatório do Banco Central do Brasil (BACEN), por total de ativo, "50 Maiores Bancos e o Consolidado do Sistema Financeiro Nacional”. Para fins de equalização das informações do modelo foram substituídas as instituições Banco do Nordeste, Credit Suisse e Banco Cooperativo Sicredi, que no relatório em 31 de dezembro de 2014 ocupavam as posições $12^{\circ}$, $15^{\circ}$ e $16^{\circ}$, respectivamente, pelas instituições: Banco de Brasília, Banco Pine e Crédit Agricole do Brasil.

A amostra tem grande representação do sistema financeiro brasileiro, ou seja, os 30 conglomerados que compõem a amostra possuem participação de $96,72 \%$ no "Consolidado bancário I" e 79,23\% no Sistema Financeiro Nacional em total de ativo, deduzido a intermediação financeira, conforme Apêndice B. 


\section{ANÁLISE DOS RESULTADOS DA PESQUISA}

Para análise dos resultados inicialmente está disposta a estatística descritiva das variáveis que compõem os modelos utilizados na pesquisa. Os resultados da estatística descritiva das variáveis são apresentados, nas tabelas para as amostras brasileiras e lusoespanholas. Na sequência estão apresentados os resultados das regressões em primeiro e em segundo estágio.

Os resultados estimados pelos modelos são considerados consistentes com as premissas para testes das hipóteses, fundamentados na análise dos testes estatísticos. O poder explicativo de $51,77 \%$ e $30,12 \%$, respectivamente para a amostra brasileira e luso-espanhola, respectivamente, do coeficiente de determinação $R^{2}$. Segundo, pela significância estatística das variáveis.

\subsection{Testes do modelo de primeiro estágio}

Para garantir a robustez ao modelo foram realizados os testes para garantir a consistência dos resultados. Para verificar a estacionariedade das séries temporais, foram realizados os testes de raízes unitárias e os testes Dickey-Fuller Aumentado (ADF) e de Phillips-Perron (PP). Para mitigar o risco em relação a multicolinearidade foi realizado o teste de Fator de Inflação de Variância (FIV). Para mitigar o risco de heterocedasticidade nos resíduos, as variáveis contábeis foram escalonadas na construção dos modelos, além disso foi utilizado o método de erros padrões seccionais SUR (PCSE), que estima parâmetros robustos assumindo a presença de heterocedasticidade e realizada análise comparativa, descritos na seção 4.5 .

A hipótese nula do teste ADF e do teste PP é de que as séries analisadas possuem raízes unitárias. As estatísticas calculadas pelo teste ADF e PP, respectivamente das amostras de Brasil e Portugal-Espanha, rejeitam a hipótese nula. Os resultados comprovam, estatisticamente, que as séries temporais analisadas são estacionárias, assim, sinalizando a robustez do modelo (1). 
Tabela 1 - Teste Raiz Unitária - Modelo (1).

\begin{tabular}{|c|c|c|c|c|}
\hline \multicolumn{5}{|c|}{ Brasil } \\
\hline Variáveis & ADF & Prob. & $\mathbf{P P}$ & Prob. \\
\hline$L L P_{\mathrm{i}, \mathrm{t}}$ & 139.189 & 0.0000 & 137.660 & 0.0000 \\
\hline$\triangle L O A N_{\mathrm{i}, \mathrm{t}}$ & 161.831 & 0.0000 & 203.065 & 0.0000 \\
\hline $\mathrm{NPL}_{\mathrm{i}, \mathrm{t}-1}$ & 98.6297 & 0.0000 & 99.0752 & 0.0000 \\
\hline$\triangle N P L_{\mathrm{i}, \mathrm{t}-1}$ & 240.818 & 0.0000 & 316.699 & 0.0000 \\
\hline$L L A_{\mathrm{i}, \mathrm{t}-1}$ & 87.1876 & 0.0000 & 95.2397 & 0.0001 \\
\hline$I N T_{\mathrm{i}, \mathrm{t}}$ & 128.264 & 0.0000 & 198.940 & 0.0000 \\
\hline$G D P_{\mathrm{t}}$ & 102.798 & 0.0000 & 110.225 & 0.0000 \\
\hline$T Y P_{\text {it }}$ & 84.6915 & 0.0000 & 93.9141 & 0.0000 \\
\hline \multicolumn{5}{|c|}{ Portugal-Espanha } \\
\hline Variáveis & ADF & Prob. & $\mathbf{P P}$ & Prob. \\
\hline$L L P_{\mathrm{i}, \mathrm{t}}$ & 77.0460 & 0.0008 & 89.2427 & 0.0000 \\
\hline$\triangle L O A N_{\mathrm{i}, \mathrm{t}}$ & 129.902 & 0.0000 & 142.463 & 0.0000 \\
\hline $\mathrm{NPL}_{\mathrm{i}, \mathrm{t}-1}$ & 106.012 & 0.0000 & 123.686 & 0.0000 \\
\hline$\triangle N P L_{\mathrm{i}, \mathrm{t}-1}$ & 102.431 & 0.0000 & 138.203 & 0.0000 \\
\hline$L L A_{\mathrm{i}, \mathrm{t}-1}$ & 69.4990 & 0.0048 & 0.00300 & 0.0000 \\
\hline$I N T_{\mathrm{i}, \mathrm{t}}$ & 125.794 & 0.0000 & 164.231 & 0.0000 \\
\hline$G D P_{\mathrm{t}}$ & 142.644 & 0.0000 & 150.887 & 0.0000 \\
\hline$T Y P_{\text {it }}$ & 119.359 & 0.0000 & 147.471 & 0.0000 \\
\hline
\end{tabular}

Fonte: Dados da pesquisa.

Para verificar a existência de autocorrelação, o que, na existência, constitui violação a uma das hipóteses de um modelo clássico de regressão linear, foi realizado o teste de DurbinWatson. A hipótese nula a ser testada é a de que os resíduos da regressão são autocorrelacionados. Os resultados da estatística dw (1,909845) e (1,687269), apresentados, rejeitam a hipótese de autocorrelação. Pelos resultados, assume-se que os estimadores podem ser considerados como melhor estimador linear não enviesado. 
Tabela 2 - Teste Durbin Watson - Modelo (1).

\begin{tabular}{ccc}
\hline & \multicolumn{2}{c}{ Países } \\
\cline { 2 - 3 } Teste & Brasil - Statistic & Portugal - Statistic \\
\hline Durbin Watson - Statistic & 1.909845 & 1.687269 \\
\hline
\end{tabular}

Fonte: Dados da pesquisa.

Os resultados do teste indicam ausência de autocorrelação, por meio do teste DurbinWatson, afastando a hipótese de autocorrelação visto que as estatísticas das amostras indicaram não autocorrelação para amostra brasileira e inconclusiva para amostra lusoespanhola.

Para a avaliação do risco de multicolinearidade foi realizado o teste de inflação de variância entre as variáveis independentes, sugerido por Gujarati e Porter (2011), por meio do FIV apurados a partir das regressões.

Tabela 3 - Resultados dos testes de inflação entre as variáveis - Modelo (1).

\begin{tabular}{|c|c|c|}
\hline \multirow{2}{*}{ Variáveis } & \multicolumn{2}{|c|}{ Países } \\
\hline & Brasil - VIF & Portugal-Espanha - VIF \\
\hline$L L P_{\mathrm{i}, \mathrm{t}}$ & 1,458366 & 1,296299 \\
\hline$\triangle L O A N_{\mathrm{i}, \mathrm{t}}$ & 1,225714 & 1,099089 \\
\hline $\mathrm{NPL}_{\mathrm{i}, \mathrm{t}-1}$ & 1,724039 & 1,352292 \\
\hline$\triangle N P L_{\mathrm{i}, \mathrm{t}-1}$ & 1,096169 & 1,096296 \\
\hline$L L A_{\mathrm{i}, \mathrm{t}-1}$ & 1,645030 & 1,251032 \\
\hline$I N T_{\mathrm{i}, \mathrm{t}}$ & 1,240458 & 1,515400 \\
\hline$G D P_{\mathrm{t}}$ & 1,021752 & 1,910520 \\
\hline$T Y P_{\text {it }}$ & 2,326918 & 1,698860 \\
\hline
\end{tabular}

Onde: $L L P_{\mathrm{i}, \mathrm{t}}$ : despesas com provisão para créditos de liquidação; $\triangle L O A N_{\mathrm{i}, \mathrm{t}}$ :variação no valor do saldo da carteira de crédito; NPL $L_{\mathrm{i}, \mathrm{t}-1}$ : saldo dos créditos vencidos e não pagos; $\triangle N P L_{\mathrm{i}, \mathrm{t}-1}$ : variação no valor dos empréstimos vencidos e não pagos; $L L A_{\mathrm{i}, \mathrm{t}-1}$ : saldo acumulado da provisão para créditos de liquidação duvidosa; $I N T_{\mathrm{i}, \mathrm{t}}:$ taxa de juros implícita média da carteira de crédito, correspondente à razão entre as receitas de operações de créditos e o saldo médio da carteira; $G D P_{\mathrm{t}}$ : taxa de variação no Produto Interno Bruto; $T Y P_{\mathrm{it}}$ : vetor das variáveis de controle que representam as proporções dos créditos distribuídas entre o setor público (PUB), setor privado (PRV) e não residentes (NRES), escalonado pelo total de ativos.

Fonte: Dados da pesquisa.

Haja vista que conforme Gujarati e Porter (2011), têm-se o comprometimento dos resultados em função da multicolinearidade quando o fator for maior que 10, os resultados afastam os problemas relacionados a multicolinearidade. 


\subsection{Estatística descritiva das variáveis utilizadas nos modelos - Amostra Brasil e Portugal-Espanha}

As Tabelas 9 e 10 apresentam as estatísticas descritivas das variáveis representativas da amostra das instituições financeiras. A média da amostra brasileira indica a expansão das carteiras de operações de créditos entre 2009 a 2014, as estatísticas da carteira lusoespanholas indicam um pequeno decréscimo no período analisado ( $\left.\triangle L O A N_{i, t_{\circ}}\right)$.

Os saldos das operações vencidas nas instituições brasileiras foram em média menores que nas instituições luso-espanholas $\left(N P L_{i, t-1}\right)$. A variação das operações vencidas apresentaram um aumento médio durante o período próximo de zero, tanto nas operações brasileiras quanto luso-espanholas $\left(\triangle N P L_{i, t}\right)$.

A provisão média defasada (redutora de ativo) da carteira de operações de créditos $\left(L L A_{i, t-1}\right)$, brasileira em média foi menor que a luso-espanhola, sugerindo que a carteira das instituições financeiras brasileiras obteve um comportamento de menor nível de provisão.

O lucro médio das instituições brasileiras foi maior que as luso-espanholas $\left(L L_{a j},\right)$. Como esperado, a taxa média das operações de créditos luso-espanholas foi inferior as brasileiras $\left(I N T_{i, t}\right)$. 
Tabela 4 - Estatística descritiva das variáveis utilizadas nos modelos (Brasil).

\begin{tabular}{|c|c|c|c|c|c|}
\hline Variáveis & Média & Mediana & Desvio-Padrão & Mínimo & Máximo \\
\hline$L L P_{\mathrm{i}, \mathrm{t}}$ & 0,00983 & 0,00790 & $-0,01013$ & 0,05818 & $-0,00116$ \\
\hline$\triangle L O A N_{\mathrm{i}, \mathrm{t}}$ & 0,02041 & 0,01853 & 0,03396 & $-0,09662$ & 0,10787 \\
\hline $\mathrm{NPL}_{\mathrm{i}, \mathrm{t}-1}$ & 0,01266 & 0,00938 & $-0,01407$ & 0,07455 & 0,00000 \\
\hline$\triangle N P L_{\mathrm{i}, \mathrm{t}-1}$ & 0,00047 & 0,00000 & 0,00933 & $-0,06089$ & 0,04130 \\
\hline$L L A_{\mathrm{i}, \mathrm{t}-1}$ & 0,01513 & 0,01430 & 0,01314 & 0,02938 & 0,07472 \\
\hline$I N T_{\mathrm{i}, \mathrm{t}}$ & 0,09310 & 0,08873 & 0,04712 & 0,00373 & 0,19995 \\
\hline$G D P_{\mathrm{t}}$ & 0,02270 & 0,01000 & 0,02447 & 0,00100 & 0,07500 \\
\hline$T Y P_{\text {it }}$ & 0,97108 & 0,99948 & 0,07907 & 0,61755 & 1,00000 \\
\hline$D P C L D d_{\mathrm{i}, \mathrm{t}}$ & 0,00004 & 0,00082 & 0,00656 & $-0,03354$ & 0,01893 \\
\hline $\operatorname{LnA} t_{\mathrm{i}, \mathrm{t}}$ & 17,42970 & 16,73709 & 1,67663 & 14,01009 & 21,08616 \\
\hline$L L a j_{\mathrm{i}, \mathrm{t}}$ & 0,01431 & 0,01336 & 0,01156 & $-0,03467$ & 0,06757 \\
\hline Variáveis & Assimetria & Curtose & Jarque-Bera & P-valor & - \\
\hline$L L P_{\mathrm{i}, \mathrm{t}}$ & $-1,86872$ & 7,52611 & 417,75720 & 0.000000 & - \\
\hline$\triangle L O A N_{\mathrm{i}, \mathrm{t}}$ & $-0,06502$ & 4,27514 & 19,92010 & 0.000047 & - \\
\hline $\mathrm{NPL}_{\mathrm{i}, \mathrm{t}-1}$ & $-1,83021$ & 6,75906 & 333,79210 & 0.000000 & - \\
\hline$\triangle N P L_{\mathrm{i}, \mathrm{t}-1}$ & $-1,38030$ & 21,89697 & 4422,18400 & 0.000000 & - \\
\hline$L L A_{\mathrm{i}, \mathrm{t}-1}$ & $-0,93581$ & 5,27675 & 105,32380 & 0.000000 & - \\
\hline$I N T_{\mathrm{i}, \mathrm{t}}$ & 0,19809 & 2,13232 & 11,03162 & 0.000000 & - \\
\hline$G D P_{\mathrm{t}}$ & 1,20171 & 3,21710 & 70,61107 & 0.000000 & - \\
\hline$T Y P_{\text {it }}$ & $-0,04668$ & 1,05624 & 45,91651 & 0.000000 & - \\
\hline$D P C L D d_{\mathrm{i}, \mathrm{t}}$ & $-1,08107$ & 7,98908 & 358,48530 & 0.000000 & - \\
\hline$L n A t_{\mathrm{i}, \mathrm{t}}$ & $-2,52122$ & 8,90259 & 730,73340 & 0.000000 & - \\
\hline$L L a j_{\mathrm{i}, \mathrm{t}}$ & 0,78122 & 6,56820 & 183,97590 & 0.000000 & - \\
\hline
\end{tabular}

Onde: $L L P_{\mathrm{i}, \mathrm{t}}$ : despesas com provisão para créditos de liquidação; $\triangle L O A N_{\mathrm{i}, \mathrm{t}}$ : variação no valor do saldo da carteira de crédito; NPL $L_{\mathrm{i}, \mathrm{t}-1}$ : saldo dos créditos vencidos e não pagos; $\triangle N P L_{\mathrm{i}, \mathrm{t}-1}$ : variação no valor dos empréstimos vencidos e não pagos; $L L A_{\mathrm{i}, \mathrm{t}-1}$ : saldo acumulado da provisão para créditos de liquidação duvidosa; $I N T_{\mathrm{i}, \mathrm{t}}$ : taxa de juros implícita média da carteira de crédito, correspondente à razão entre as receitas de operações de créditos e o saldo médio da carteira; $G D P_{\mathrm{t}}$ : taxa de variação no Produto Interno Bruto; $T Y P_{\mathrm{it}}$ : vetor das variáveis de controle que representam as proporções dos créditos distribuídas entre o setor público (PUB), setor privado (PRV) e não residentes (NRES), escalonado pelo total de ativos; DPCLDd $d_{\mathrm{i}, \mathrm{t}}$ : componente discricionário das despesas de provisão para créditos de liquidação duvidosa, resíduos do modelo de primeiro estágio; LnAt ${ }_{\mathrm{i}, \mathrm{t}}$ : resultado ajustado pelas despesas com provisões, escalonado pelos ativos totais; $L L a j_{\mathrm{i}, \mathrm{t}}$ : logaritmo natural dos ativos totais, variável representativa do porte das instituições financeiras.

Fonte: Dados da pesquisa. 
Tabela 5 - Estatística descritiva das variáveis utilizadas nos modelos (Portugal-Espanha).

\begin{tabular}{|c|c|c|c|c|c|}
\hline Variáveis & Média & Mediana & Desvio-Padrão & Mínimo & Máximo \\
\hline$L L P_{\mathrm{i}, \mathrm{t}}$ & 0,00514 & 0,00412 & 0,00590 & $-0,02884$ & 0,03397 \\
\hline$\triangle L O A N_{\mathrm{i}, \mathrm{t}}$ & $-0,00135$ & $-0,00615$ & 0,04086 & $-0,14530$ & 0,13933 \\
\hline $\mathrm{NPL}_{\mathrm{i}, \mathrm{t}-1}$ & 0,03182 & 0,02685 & $-0,02777$ & 0,15330 & 0,00000 \\
\hline$\triangle N P L_{\mathrm{i}, \mathrm{t}-1}$ & 0,00381 & 0,00210 & 0,00877 & $-0,02084$ & 0,08251 \\
\hline$L L A_{\mathrm{i}, \mathrm{t}-1}$ & 0,02615 & 0,02119 & 0,02021 & 0,00016 & 0,16754 \\
\hline$I N T_{\mathrm{i}, \mathrm{t}}$ & 0,04211 & 0,03525 & 0,02941 & 0,00021 & 0,18125 \\
\hline$G D P_{\mathrm{t}}$ & $-0,01150$ & $-0,01830$ & 0,01638 & $-0,04030$ & 0,01900 \\
\hline$T Y P_{\text {it }}$ & 0,80311 & 0,93562 & 0,25584 & 0,19411 & 1,00000 \\
\hline$D P C L D d_{\mathrm{i}, \mathrm{t}}$ & $-0,00006$ & 0,00052 & 0,00509 & $-0,02545$ & 0,02068 \\
\hline $\operatorname{LnA} t_{\mathrm{i}, \mathrm{t}}$ & 14,51388 & 14,55784 & 2,88694 & 9,12542 & 19,36220 \\
\hline$L L a j_{\mathrm{i}, \mathrm{t}}$ & 0,00636 & 0,00536 & 0,01879 & $-0,06780$ & 0,13711 \\
\hline Variáveis & Assimetria & Curtose & Jarque-Bera & P-valor & - \\
\hline$L L P_{\mathrm{i}, \mathrm{t}}$ & $-0,75975$ & 11,76493 & 824,30050 & 0.000000 & - \\
\hline$\triangle L O A N_{\mathrm{i}, \mathrm{t}}$ & 0,61246 & 6,04544 & 112,24110 & 0.000000 & - \\
\hline $\mathrm{NPL}_{\mathrm{i}, \mathrm{t}-1}$ & $-1,81455$ & 7,54758 & 352,61260 & 0.000000 & - \\
\hline$\triangle N P L_{\mathrm{i}, \mathrm{t}-1}$ & 4,12762 & 36,12736 & 12141,37000 & 0.000000 & - \\
\hline$L L A_{\mathrm{i}, \mathrm{t}-1}$ & $-2,18532$ & 12,46231 & 1131,64400 & 0.000000 & - \\
\hline$I N T_{\mathrm{i}, \mathrm{t}}$ & 1,73779 & 7,54292 & 340,81030 & 0.000000 & - \\
\hline$G D P_{\mathrm{t}}$ & $-0,50290$ & 2,05161 & 19,90687 & 0.000048 & - \\
\hline$T Y P_{\text {it }}$ & $-0,65130$ & 1,73065 & 34,45850 & 0.000000 & - \\
\hline$D P C L D d_{\mathrm{i}, \mathrm{t}}$ & $-1,23198$ & 9,15594 & 457,98580 & 0.000000 & - \\
\hline $\operatorname{LnAt}_{\mathrm{i}, \mathrm{t}}$ & 2,91735 & 10,26826 & 904,90820 & 0.000000 & - \\
\hline$L L a j_{\mathrm{i}, \mathrm{t}}$ & 2,41368 & 26,31874 & 5906,94800 & 0.000000 & - \\
\hline
\end{tabular}

Onde: $L L P_{\mathrm{i}, \mathrm{t}}$ : despesas com provisão para créditos de liquidação; $\triangle L O A N_{\mathrm{i}, \mathrm{t}}$ : variação no valor do saldo da carteira de crédito; NPL $L_{\mathrm{i}, \mathrm{t}-1}$ : saldo dos créditos vencidos e não pagos; $\triangle N P L_{\mathrm{i}, \mathrm{t}-1}$ : variação no valor dos empréstimos vencidos e não pagos; $L L A_{\mathrm{i}, \mathrm{t}-1}$ : saldo acumulado da provisão para créditos de liquidação duvidosa; $I N T_{\mathrm{i}, \mathrm{t}}$ : taxa de juros implícita média da carteira de crédito, correspondente à razão entre as receitas de operações de créditos e o saldo médio da carteira; $G D P_{\mathrm{t}}$ : taxa de variação no Produto Interno Bruto; $T Y P_{\mathrm{it}}$ : vetor das variáveis de controle que representam as proporções dos créditos distribuídas entre o setor público (PUB), setor privado (PRV) e não residentes (NRES), escalonado pelo total de ativos; DPCLDd $d_{\mathrm{i}, \mathrm{t}}$ : componente discricionário das despesas de provisão para créditos de liquidação duvidosa, resíduos do modelo de primeiro estágio; LnAt i,t: resultado ajustado pelas despesas com provisões, escalonado pelos ativos totais; $L L a j_{\mathrm{i}, \mathrm{t}}$ : logaritmo natural dos ativos totais, variável representativa do porte das instituições financeiras.

Fonte: Dados da pesquisa. 


\subsection{Análise dos resultados estimados - Modelo (1) - Amostra Brasil}

Para testes de hipóteses da pesquisa e de acordo com o método estabelecido foi realizado a estimação do componente discricionário das despesas de provisão para créditos de liquidação duvidosa, assim utilizando o modelo (1) os resíduos da equação representam o componente não discricionário das despesas com provisão para créditos de liquidação duvidosa, os quais são utilizados no modelo de segundo estágio.

Os resultados estão apresentados por amostra, onde está descrita a análise para cada amostra e comparação em relação aos resultados. Os resultados foram analisados com base no nível de significância de $10 \%$.

Tabela 6 - Resumo dos resultados estatísticos - Modelo (1) - Brasil.

$$
\begin{aligned}
L L P_{i, t}=\beta_{0}+\beta_{i} & +\beta_{1} \Delta L O A N_{i, t}+\beta_{2} N P L_{i, t-1}+\beta_{a} \Delta N P L_{i, t}+\beta_{4} L L A_{i_{i} t-1}+\beta_{5} I N T_{i, t}+\beta_{6} G D P_{t}+\psi_{1} \\
& <T Y P_{i_{i}, t}>+\varepsilon_{i t}
\end{aligned}
$$

\section{LS - Ordinary}

\begin{tabular}{|c|c|c|c|}
\hline Variable & Coefficient & t-Statistic & Prob. \\
\hline $\mathrm{C}$ & -2447360 & $-2,099525$ & 0,03670 \\
\hline$\triangle L O A N_{\mathrm{i}, \mathrm{t}}$ & 0,017877 & 1,292658 & 0,19730 \\
\hline $\mathrm{NPL}_{\mathrm{i}, \mathrm{t}-1}$ & 0,300387 & 6,478320 & $0,00000 *$ \\
\hline$\triangle N P L_{\mathrm{i}, \mathrm{t}-1}$ & 0,087490 & 1,732675 & $0,08430 * * *$ \\
\hline$L L A_{\mathrm{i}, \mathrm{t}-1}$ & 0,091481 & 2,039289 & $0,04240 *$ \\
\hline$I N T_{\mathrm{i}, \mathrm{t}}$ & $-0,037531$ & $-4,171022$ & $0,00000 *$ \\
\hline$G D P_{\mathrm{t}}$ & 26200,96 & 1,601739 & 0,11040 \\
\hline$T Y P_{\text {it }}$ & 0,001208 & 0,919901 & 0,35850 \\
\hline R-squared & 0,52177 & & \\
\hline Adjusted R-squared & 0,46453 & & \\
\hline F-statistic & 9,115487 & & \\
\hline $\operatorname{Prob}($ F-statistic) & 0,000000 & & \\
\hline
\end{tabular}

Dependent Variable: $L L P_{\mathrm{i}, \mathrm{t}}$

Onde: (*) Significativa a $1 \%$ - (**) Significativa a 5\% - (***) Significativa a $10 \%$.

Onde: $\triangle L O A N_{\mathrm{i}, \mathrm{t}}$ : variação no valor do saldo da carteira de crédito; $\mathrm{NPL}_{\mathrm{i}, \mathrm{t}-\mathrm{1}}$ : saldo dos créditos vencidos e não pagos; $\triangle N P L_{\mathrm{i}, \mathrm{t}-1}$ : variação no valor dos empréstimos vencidos e não pagos; $L L A_{\mathrm{i}, \mathrm{t}-1}$ : saldo acumulado da provisão para créditos de liquidação duvidosa; $I N T_{\mathrm{i}, \mathrm{t}}$ t taxa de juros implícita média da carteira de crédito, correspondente à razão entre as receitas de operações de créditos e o saldo médio da carteira; $G D P_{\mathrm{t}}$ : taxa de variação no Produto Interno Bruto; TYP it: vetor das variáveis de controle que representam as proporções dos créditos distribuídas entre o setor público (PUB), setor privado (PRV) e não residentes (NRES), escalonado pelo total de ativos.

Fonte: Dados da pesquisa. 
O resultado da significância global do modelo, utilizando o teste (F) confirma que o modelo conjuntamente é significativo, analisando conjuntamente a hipótese nula de que os coeficientes estimados pela regressão são simultaneamente iguais a zero. O resultado apresentado pelo teste F $(9,115487)$, com p-value de $(0,00000)$, rejeita a hipótese nula, ou seja, as variações observadas nas despesas de provisão para créditos de liquidação duvidosa são decorrentes das alterações das variáveis explicativas e não ocorrem, somente, em função da variação no termo residual. Os resultados das estatísticas (t) demonstram, individualmente, a significância dos estimadores.

A análise do coeficiente de determinação, $\left(\mathrm{R}^{2}\right)$ ajustado $(0,46453)$, indica que as variáveis explanatórias utilizadas no modelo, para identificar o componente não discricionário, explicam 46,4\% das despesas de provisão para créditos de liquidação duvidosa constituídas do período. Os resíduos 54,6\%, são utilizados como proxy para o componente discricionário das despesas de provisão para créditos de liquidação duvidosa, que é a variável dependente no segundo estágio. Os resultados indicam à utilização do componente discricionário das despesas de provisão para créditos de liquidação duvidosa para gerenciamento de resultados.

Os resultados confirmaram a relação positiva esperadas da variação do saldo das operações de créditos $\left(\triangle L O A N_{\mathrm{i}, \mathrm{t}}\right)$ em relação as despesas com provisão para créditos de liquidação duvidosa, entretanto, a variável não sendo significante. Para as operações vencidas defasadas, os resultados da regressão mostram que o sinal do coeficiente é positivo, confirmando a expectativa e a característica de que os créditos deteriorados influenciam de forma mais significativa as provisões constituídas, de forma consistente com o disposto na Resolução CNM n. 2.682/1999. A estatística t (6,478320), com p-valor de (0,0000), comprova que variável explica o comportamento do componente não discricionário das despesas de provisão para créditos de liquidação duvidosa. A variação das operações vencidas $\left(\triangle N P L_{i, t-1}\right)$ também foram significativas e com sinal positivo, confirmando igualmente a expectativa de influência na constituição da provisão e significância. $O$ saldo da provisão no período anterior $\left(L L A_{i, t-1}\right)$ teve relação positiva, não há relação esperada da variável. A taxa média de juros $\left(I N T_{i, t}\right)$, dada pela razão entre as receitas de operações de créditos e carteira de crédito, teve relação negativa indicando que o aumento das despesas leva a remuneração das operações de créditos são reduzidas à medida que há a deterioração das operações de créditos. A relação da atividade econômica, dado pela variável (GDP), Produto Interno Bruto (PIB), embora não significativa teve uma relação positiva, indicando que com o aumento da 
atividade econômica com consequente efeito na carteira de operações de créditos há um incremento nas despesas de provisão para créditos de liquidação duvidosa.

A variável vetor de controle $\left(T Y P_{i, t}\right)$ que representa as proporções dos créditos distribuídas entre o setor público, setor privado e não residentes não foi significativa, entretanto, influência positivamente a variável dependente.

As operações vencidas $\left(N P L_{i, t-1}\right)$ tiveram mais influência sobre a constituição da provisão para créditos de liquidação duvidosa que as demais variáveis, resultado este que é racional, dado o efeito da deterioração que se intensifica. As instituições financeiras possuem política para análise de créditos com critérios considerando risco dentro dos tipos de operações de créditos realizadas, as operações são classificadas em níveis de risco de maior ou menor escala, o que representa a incidência de níveis diferentes de provisão. Os critérios de constituição de provisão para perda utilizados pelas instituições financeiras consideram modelo que abrange critérios que capturam estimativas de perdas esperadas, as despesas com provisão para créditos de liquidação duvidosa são potencializadas com a deterioração da situação dos créditos vencidos refletindo o efeito da inadimplência por meio do aumento das despesas com provisão.

As provisões no período anterior $\left(L L A_{i, t-1}\right)$ sugerem que as provisões realizadas influenciam as despesas com provisões para créditos de liquidação duvidosa, o que é intuitivo, haja vista que as provisões constituem uma mensuração de perda para o créditos, que, quando deteriorado, levará a um aumento das despesas com provisão pela continua deterioração.

A taxa média de juros $\left(I N T_{i, t}\right)$, também representativa com sinal negativo relacionando o aumento das despesas com a remuneração das operações, indica a redução da remuneração das operações de créditos à medida que há deterioração da carteira.

\subsection{Análise dos resultados estimados Modelo (1) - Amostra Portugal-Espanha}

No teste das hipóteses da pesquisa e de acordo com o método igualmente aplicado para a amostra brasileira foi realizado a estimação do componente discricionário das despesas de provisão para créditos de liquidação duvidosa, utilizando o modelo (1), os resíduos da equação representam o componente não discricionário das despesas com provisão para créditos de liquidação duvidosa, os quais são utilizados no modelo de segundo estágio.

A seguir, têm-se o resumo dos resultados da regressão do primeiro estágio para a amostra luso-espanhola. 
Tabela 7 - Resumo dos resultados estatísticos - Modelo (1) - Portugal-Espanha.

\begin{tabular}{|c|c|c|c|}
\hline \multicolumn{4}{|c|}{$\begin{aligned} L L P_{\mathrm{i}, t}=\beta_{0}+\beta_{\mathrm{i}} & +\beta_{1} \Delta L O A N_{\mathrm{i}, \mathrm{t}}+\beta_{2} N P L_{\mathrm{i}, \mathrm{t}-1}+\beta_{\mathrm{a}} \Delta N P L_{\mathrm{i}, \mathrm{t}}+\beta_{4} L L A_{\mathrm{i}, t-1}+\beta_{5} I N T_{\mathrm{i}, \mathrm{t}}+\beta_{6} G D P_{\mathrm{t}}+\psi_{1} \\
& <T Y P_{\mathrm{i}, \mathrm{t}}>+\varepsilon_{\mathrm{i}, \mathrm{t}}\end{aligned}$} \\
\hline \multicolumn{4}{|l|}{ LS - Ordinary } \\
\hline \multicolumn{4}{|c|}{ Dependent Variable: $L L P_{\mathrm{i}, \mathrm{t}}$} \\
\hline Variable & Coefficient & t-Statistic & Prob. \\
\hline $\mathrm{C}$ & -3416983 & $-3,080778$ & 0,0023 \\
\hline$\triangle L O A N_{\mathrm{i}, \mathrm{t}}$ & 0,013409 & 1,384988 & 0,1674 \\
\hline $\mathrm{NPL}_{\mathrm{i}, \mathrm{t}-1}$ & 0,062258 & 2,521593 & $0,0124 * *$ \\
\hline$\triangle N P L_{\mathrm{i}, \mathrm{t}-1}$ & 0,131723 & 2,852767 & $0,0047 *$ \\
\hline$L L A_{\mathrm{i}, \mathrm{t}-1}$ & $-0,052201$ & $-1,632389$ & 0,1040 \\
\hline$I N T_{\mathrm{i}, \mathrm{t}}$ & 0,004080 & 0,293868 & 0,7691 \\
\hline$G D P_{\mathrm{t}}$ & $7.930,069$ & 1,759524 & $0,0799 * * *$ \\
\hline$T Y P_{\text {it }}$ & $-0,000577$ & $-0,465217$ & 0,6422 \\
\hline R-squared & 0,301254 & & \\
\hline Adjusted R-squared & 0,216271 & & \\
\hline F-statistic & 3,544890 & & \\
\hline Prob(F-statistic) & 0,000000 & & \\
\hline
\end{tabular}

Onde: (*) Significativa a 1\%; (**) Significativa a 5\%; (***) Significativa a $10 \%$.

Onde: $\triangle L O A N_{\mathrm{i}, \mathrm{t}}$ : variação no valor do saldo da carteira de crédito; $\mathrm{NPL}_{\mathrm{i}, \mathrm{t}-1}$ : saldo dos créditos vencidos e não pagos; $\triangle N P L_{\mathrm{i}, \mathrm{t}-1}$ : variação no valor dos empréstimos vencidos e não pagos; $L L A_{\mathrm{i}, \mathrm{t}-1}$ : saldo acumulado da provisão para créditos de liquidação duvidosa; $I N T_{\mathrm{i}, \mathrm{t}}$ t taxa de juros implícita média da carteira de crédito, correspondente à razão entre as receitas de operações de créditos e o saldo médio da carteira; $G D P_{\text {t: }}$ taxa de variação no Produto Interno Bruto; $T Y P_{\text {it: }}$ vetor das variáveis de controle que representam as proporções dos créditos distribuídas entre o setor público (PUB), setor privado (PRV) e não residentes (NRES), escalonado pelo total de ativos.

Fonte: Dados da pesquisa.

O resultado da significância global do modelo, utilizando o teste $(\mathrm{F})$ confirma que o modelo conjuntamente é significativo, analisando conjuntamente a hipótese nula de que os coeficientes estimados pela regressão são simultaneamente iguais a zero. O resultado apresentado pelo teste $\mathrm{F}(3,544890)$, com $p$-value de 0,00000 , rejeita a hipótese nula, ou seja, as variações observadas nas despesas de provisão para créditos de liquidação duvidosa são decorrentes das alterações das variáveis explicativas e não ocorrem, somente, em função da variação no termo residual. Os resultados das estatísticas (t) demonstram que os coeficientes estimados das variáveis pela regressão, individualmente, são significativos. 
A análise do coeficiente de determinação $\left(\mathrm{R}^{2}\right)$ ajustado $(0,216271)$ indica que as variáveis explanatórias utilizadas no modelo, para identificar o componente não discricionário, explicam $21,62 \%$ das despesas de provisão para créditos de liquidação duvidosa constituídas do período. Os resíduos 78,38\%, são utilizados como proxy para o componente discricionário das despesas de provisão para créditos de liquidação duvidosa, que é a variável dependente no segundo estágio. Os resultados indicam a utilização do componente discricionário das despesas de provisão para créditos de liquidação duvidosa como meio para gerenciamento de gerenciamento de resultados.

Os resultados confirmaram a relação positiva esperadas da variação do saldo das operações de créditos $\left(\triangle L O A N_{\mathrm{i}, \mathrm{t}}\right)$ em relação as despesas com provisão para créditos de liquidação duvidosa, contudo, a variável não foi significativa. O saldo das operações vencidas defasadas tiveram coeficiente positivo, confirmando a expectativa e a característica de que os créditos deteriorados influenciam de forma mais significativa as provisões constituídas, a Carta Circular n. 02/2014 do Banco de Portugal, que estabelece os critérios de imparidade da carteira de crédito, estabelece critérios para cumprimento de níveis mínimos de provisionamento, variável sendo significativa a 5\%. As orientações incorporam para constituição de provisão aspectos como: identificação dos indícios de imparidade; exposição individualmente significativa; exposições analisadas coletivamente; julgamentos, pressupostos e premissas que devem ser consideradas, estando as operações sujeitas a avaliações com critérios qualitativos de imparidade, assim as operações provisionadas estão altamente sujeitas ao aumento sensibilizarem as despesas com provisão haja vista a deterioração.

A estatística t (2,521593), com p-value de 0,0124, confirma que variável explica o comportamento do componente não discricionário das despesas de provisão para créditos de liquidação duvidosa. A variação das operações vencidas $\left(\triangle N P L_{i, t-1}\right)$ também foram significativas e com sinal positivo, confirmando igualmente a expectativa de influência na constituição da provisão e significância. O saldo da provisão no período anterior $\left(L L A_{i, t-1}\right)$, não foi significativa, contudo a relação negativa, indica que o montante da provisão foi considerada para constituição de novas provisões, a relação negativa sugere que a provisão anterior é reduzida no período, não havia relação esperada para a variável. A taxa média de juros $\left(I N T_{i, t}\right)$, dada pela razão entre as receitas de operações de créditos e carteira de crédito, teve relação positiva indicando o aumento das despesas com a respectiva remuneração média das operações, entretanto, diferentemente do amostra brasileira não são significativas, 
indicando que as operações com altas taxas no Brasil é um componente relevante de influência nas provisões. A relação da atividade econômica, dado pela variável $(G D P)$, teve relação positiva, indicando que com o aumento da atividade econômica tem efeito na carteira de operações de créditos, e sofre incremento nas despesas de provisão para créditos de liquidação duvidosa, considerando que há uma relação de aumento de operações, mostrandose variável explicativa relevante, situação oposta da amostra brasileira, indicando maior nível de uso de discricionariedade no Brasil do que em Portugal e Espanha.

A variável de controle $\left(T Y P_{i, t}\right)$, não foi significativa, tendo sinal negativo, assim com influência negativa nas despesas com provisão, indicando menor nível de provisão na carteira privada no sistema financeiro Português-Espanhol.

As operações vencidas e variação das operações vencidas $\left(N P L_{i, t-1}\right)$ e $\left(\Delta N P L_{i, t-1}\right)$ foram as variáveis mais significativas para constituição das despesas com provisão para créditos de liquidação duvidosa, resultado este intuitivo, dado o efeito da deterioração que se intensifica com o passar do tempo. Assim, sendo um resultado consistente com as premissas existentes das regras para constituição das provisões.

\subsection{Procedimentos de robustez primeiro estágio}

Com o objetivo de mitigar o risco de heterocedasticidade nos resíduos, as variáveis contábeis foram escalonadas na construção dos modelos. E ainda, fez-se uso do método de erros padrões seccionais SUR (PCSE), que estima parâmetros robustos assumindo a presença de heterocedasticidade e realizada análise comparativa. 
Tabela 8 - Resumo dos resultados estatísticos - Modelo (1) - Método de erros padrões seccionais SUR (PCSE) - Brasil.

\begin{tabular}{|c|c|c|c|}
\hline \multicolumn{4}{|c|}{$\begin{aligned} L L P_{i, t}=\beta_{0}+\beta_{i} & +\beta_{1} \Delta L O A N_{i, t}+\beta_{2} N P L_{i, t-1}+\beta_{3} \Delta N P L_{i, j}+\beta_{4} L L A_{i, t-1}+\beta_{5} I N T_{i, t}+\beta_{6} G D P_{t}+\psi_{1} \\
& <T Y P_{i, t}>+\varepsilon_{i t}\end{aligned}$} \\
\hline \multicolumn{4}{|l|}{ LS SUR (PCSE) } \\
\hline Variable & Coefficient & t-Statistic & Prob. \\
\hline $\mathrm{C}$ & -2447360 & $-1,8681501,868150$ & 0,0629 \\
\hline$\triangle L O A N_{\mathrm{i}, \mathrm{t}}$ & 0,017877 & 1,257240 & 0,2102 \\
\hline $\mathrm{NPL}_{\mathrm{i}, \mathrm{t}-1}$ & 0,300387 & 5,687697 & $0,0000^{*}$ \\
\hline$\Delta N P L_{\mathrm{i}, \mathrm{t}-1}$ & 0,087490 & 1,596323 & 0,1116 \\
\hline$L L A_{\mathrm{i}, \mathrm{t}-1}$ & 0,091481 & 1,913836 & $0,0567 * * *$ \\
\hline$I N T_{\mathrm{i}, \mathrm{t}}$ & 0,037531 & 3,725784 & $0,0002 *$ \\
\hline$G D P_{\mathrm{t}}$ & 26200,96 & 1,641507 & 0,1019 \\
\hline$T Y P_{\text {it }}$ & 0,001208 & 0,822883 & 0,4113 \\
\hline R-squared & 0,52177 & & \\
\hline Adjusted R-squared & 0,46453 & & \\
\hline F-statistic & 9,115487 & & \\
\hline $\operatorname{Prob}($ F-statistic $)$ & 0,000000 & & \\
\hline
\end{tabular}

Onde: (*) Significativa a 1\%; (**) Significativa a 5\%; (***) Significativa a $10 \%$.

Onde: $\triangle L O A N_{\mathrm{i}, \mathrm{t}}$ : variação no valor do saldo da carteira de crédito; $\mathrm{NPL}_{\mathrm{i}, \mathrm{t}-\mathrm{l}}$ : saldo dos créditos vencidos e não pagos; $\triangle N P L_{\mathrm{i}, \mathrm{t}-1}$ : variação no valor dos empréstimos vencidos e não pagos; $L L A_{\mathrm{i}, \mathrm{t}-1}$ : saldo acumulado da provisão para créditos de liquidação duvidosa; $I N T_{\mathrm{i}, \mathrm{t}}$ : taxa de juros implícita média da carteira de crédito, correspondente à razão entre as receitas de operações de créditos e o saldo médio da carteira; $G D P$ t: taxa de variação no Produto Interno Bruto; $T Y P_{\text {it: }}$ vetor das variáveis de controle que representam as proporções dos créditos distribuídas entre o setor público (PUB), setor privado (PRV) e não residentes (NRES), escalonado pelo total de ativos.

Fonte: Dados da pesquisa.

Analisando os resultados comparativamente ao que foi observado aos resultados pelo método de erros padrões seccionais SUR (PCSE), a significância geral resultado do teste (F) confirma que o modelo conjuntamente é significativo, e afasta a hipótese nula de que os coeficientes estimados pela regressão são simultaneamente iguais a zero. O resultado apresentado pelo teste $\mathrm{F}(9,115487)$, com p-value de $(0,00000)$ em ambos os métodos, confirmam a rejeição da hipótese nula. A análise do coeficiente de determinação, $\left(\mathrm{R}^{2}\right)$ ajustado (0,46453), em ambos os métodos, indica o nível de explicação da variável dependente pelas variáveis explanatórias.

Os resultados confirmaram a relação positiva esperadas da variação do saldo das operações de créditos $\left(\triangle L O A N_{\mathrm{i}, \mathrm{t}}\right)$ em relação as despesas com provisão para créditos de liquidação duvidosa, entretanto, a variável não sendo significante em ambos os métodos. As 
operações vencidas defasadas tiveram em ambos os métodos coeficiente positivo, confirmando a expectativa influência de forma mais significativa às provisões constituídas e consistente com o disposto na Resolução CMN n. 2.682/1999. A estatística t $(6,478320)$ e $(5,687697)$, com p-valor de $(0,0000)$ e $(0,0000)$, para os métodos, comprova que variável explica o comportamento do componente não discricionário das despesas de provisão para créditos de liquidação duvidosa. A variação das operações vencidas $\left(\triangle N P L_{i, t-1}\right)$ tiveram sinal positivo, não sendo relevante no método de erros padrões seccionais SUR (PCSE). O saldo da provisão no período anterior ( $\left.L L A_{i, t-1}\right)$ teve relação positiva, sendo relevantes em ambos os métodos. A taxa média de juros $\left(I N T_{i, t}\right)$, dada pela razão entre as receitas de operações de créditos e carteira de crédito, sendo significativa, em ambos os métodos, indicando que as taxas brasileiras assumem uma alta remuneração do risco da concessão das operações de créditos e esse risco se efetiva tendo a necessidade da constituição das provisões para créditos de liquidação duvidosa.

A variável vetor de controle $\left(T Y P_{i, t}\right)$ que representa as proporções dos créditos distribuídas entre o setor público, setor privado e não residentes não foi significativa, em ambos os métodos.

As operações vencidas $\left(N P L_{i, t-1}\right)$ tiveram mais influência sobre a constituição da provisão para créditos de liquidação duvidosa que as demais variáveis, em ambos os métodos, resultado que corrobora que o efeito da deterioração se intensifica. 
Tabela 9 - Resumo dos resultados estatísticos - Modelo (1) - Método de erros padrões seccionais SUR (PCSE) - Portugal-Espanha.

$$
\begin{aligned}
L L P_{\mathrm{i}, t}=\beta_{0}+\beta_{\mathrm{i}} & +\beta_{1} \Delta L O A N_{\mathrm{i}, t}+\beta_{2} N P L_{\mathrm{i}, t-1}+\beta_{\mathrm{a}} \Delta N P L_{\mathrm{i}, \mathrm{t}}+\beta_{4} L L A_{\mathrm{i}, t-1}+\beta_{5} I N T_{\mathrm{i}, t}+\beta_{6} G D P_{\mathrm{t}}+\psi_{1} \\
& <T Y P_{\mathrm{i}, t}>+\varepsilon_{\mathrm{it}}
\end{aligned}
$$

\begin{tabular}{|c|c|c|c|}
\hline Variable & Coefficient & t-Statistic & Prob. \\
\hline $\mathrm{C}$ & -3416983 & $-2,681616$ & 0,0079 \\
\hline$\triangle L O A N_{\mathrm{it}}$ & 0,013409 & 1,183270 & 0,2380 \\
\hline$N_{P L}, t-1$ & 0,062258 & 2,333315 & $0,0205^{* *}$ \\
\hline$\triangle N P L_{\mathrm{i}, \mathrm{t}-1}$ & 0,131723 & 2,141380 & $0,0333 * *$ \\
\hline$L L A_{\mathrm{i}, \mathrm{t}-1}$ & $-0,052201$ & $-1,428205$ & 0,1546 \\
\hline$I N T_{\mathrm{i}, \mathrm{t}}$ & 0,004080 & 0,311753 & 0,7555 \\
\hline$G D P_{\mathrm{t}}$ & $7.930,069$ & 1,760238 & $0,0797 * * *$ \\
\hline$T Y P_{\text {it }}$ & $-0,000577$ & $-0,468464$ & 0,6399 \\
\hline R-squared & 0,301254 & & \\
\hline Adjusted R-squared & 0,216271 & & \\
\hline F-statistic & 3,544890 & & \\
\hline $\operatorname{Prob}($ F-statistic) & 0,000000 & & \\
\hline
\end{tabular}

LS SUR (PCSE)

Onde: (*) Significativa a 1\%; (**) Significativa a 5\%; (***) Significativa a $10 \%$.

Onde: $\triangle L O A N_{\mathrm{i}, \mathrm{t}}$ : variação no valor do saldo da carteira de crédito; $\mathrm{NPL}_{\mathrm{i}, \mathrm{t}-1}$ : saldo dos créditos vencidos e não pagos; $\triangle N P L_{\mathrm{i}, \mathrm{t}-1}$ : variação no valor dos empréstimos vencidos e não pagos; $L L A_{\mathrm{i}, \mathrm{t}-1}$ : saldo acumulado da provisão para créditos de liquidação duvidosa; $I N T_{\mathrm{i}, \mathrm{t}}$ t taxa de juros implícita média da carteira de crédito, correspondente à razão entre as receitas de operações de créditos e o saldo médio da carteira; $G D P_{\mathrm{t}}$ : taxa de variação no Produto Interno Bruto; TYP it: vetor das variáveis de controle que representam as proporções dos créditos distribuídas entre o setor público (PUB), setor privado (PRV) e não residentes (NRES), escalonado pelo total de ativos.

Fonte: Dados da pesquisa.

O resultado da significância global do modelo, utilizando o teste $(\mathrm{F})$ confirma que o modelo conjuntamente é significativo, analisando a hipótese nula de que os coeficientes estimados pela regressão são simultaneamente iguais a zero. O resultado apresentado pelo teste $\mathrm{F}$ (3,544890), com p-value de 0,00000, em ambos os métodos, rejeita a hipótese nula, de que as variações observadas nas despesas de provisão para créditos de liquidação duvidosa são decorrentes das alterações das variáveis explicativas e não ocorrem, somente, em função da variação no termo residual.

A análise do coeficiente de determinação $\left(\mathrm{R}^{2}\right)$ ajustado $(0,216271)$ em ambos os métodos, indica que as variáveis explanatórias utilizadas no modelo, explicam 21,62\% das despesas de provisão para créditos de liquidação duvidosa constituídas do período. Os 
resultados indicam a utilização do componente discricionário das despesas de provisão para créditos de liquidação duvidosa como meio para gerenciamento de gerenciamento de resultados.

Os resultados confirmaram a relação positiva esperada da variação do saldo das operações de créditos $\left(\triangle L O A N_{\mathrm{i}, \mathrm{t}}\right)$ em relação as despesas com provisão para créditos de liquidação duvidosa, contudo, a variável não foi significativa em ambos os métodos. O saldo das operações vencidas defasadas $\left(N P L_{i, t-1}\right)$, tiveram coeficiente positivo, sendo significativa a $5 \%$, em ambos os métodos. A variação das operações vencidas $\left(\triangle N P L_{i, t-1}\right)$ também foram significativas e com sinal positivo. O saldo da provisão no período anterior $\left(L L A_{i, t-1}\right)$ não foi significativa em ambos os métodos. Contudo, a relação negativa indica que o montante da provisão foi considerada para constituição de novas provisões; e ainda, sugere que a provisão anterior é reduzida no período, ou seja, não havia relação esperada para a variável. A taxa média de juros $\left(I N T_{i, t}\right)$ teve relação positiva indicando o aumento das despesas com a respectiva remuneração média das operações, entretanto, diferentemente do amostra brasileira não são significativas, em ambos os métodos, confirmando que as operações com altas taxas no Brasil são um componente relevante de influência nas provisões. A relação da atividade econômica $(G D P)$ teve relação positiva, indicando o aumento da atividade econômica, ou seja, tem efeito positivo na carteira de operações de créditos e reflexo nas respectivas provisões para créditos de liquidação duvidosa, considerando que há uma relação de aumento de operações, mostrando-se variável explicativa relevante em ambos os métodos, situação oposta da brasileira, indicando que um maior nível de uso de discricionariedade no Brasil do que em Portugal e Espanha.

A variável de controle $\left(T Y P_{i, t}\right)$ não foi significativa para nenhum dos métodos, teve sinal negativo, com influência negativa nas despesas com provisão, indicando menor nível de provisão na carteira privada no sistema financeiro Português-Espanhol.

As operações vencidas e variação das operações vencidas $\left(N P L_{i, t-1}\right)$ e $\left(\triangle N P L_{i, t-1}\right)$ foram as variáveis mais significativas em ambos os métodos, resultado esse esperado, visto que o efeito da piora das operações de créditos intensifica-se no tempo.

Em resumo, confirmou-se a consistência do modelo, tendo em vista a manutenção da relevância dos $\left(\mathrm{R}^{2}\right)$ e ( $\mathrm{R}^{2}$ ajustado) em ambos os métodos, assim no mesmo sentido o teste $(\mathrm{F})$ de ambos os métodos obteve os mesmos resultados, corroborando a significância geral do modelo. Assim, o modelo obteve êxito no propósito definido, que foi obter os resíduos utilizados como variável dependente no segundo estágio. 


\subsection{Análise comparativa dos resultados estimados Modelo (1) - Brasil e Portugal- Espanha}

A análise dos resultados entre as amostras indica consistência dos resultados esperados das variáveis, conforme se segue:

- Foi observada relação positiva entre a variação da carteira de operações de créditos e as despesas com provisão para créditos de liquidação duvidosa para ambas as amostras (brasileira e luso-espanhola), confirmando a expectativa de que o aumento na carteira de operações de créditos está positivamente relacionado ao aumento das despesas de provisão para créditos de liquidação duvidosa, comportamento esse indicando latência do componente não discricionário.

- A variável saldos das operações vencidas defasadas apresentou em ambas as amostras os resultados esperados, indicando que as operações vencidas, estão positivamente relacionados com a constituição da provisão, em função que a baixa qualidade dos créditos determina a necessidade de incrementos de provisão para créditos de liquidação duvidosa.

- Assim como os saldos das operações vencidas defasadas, a variação das mesmas esperava-se uma relação positiva, confirmada em ambas as amostras pelo mesmo racional que indica a relação positiva.

- O estoque de provisão para operações de créditos no período anterior indicou relações diferentes entre as amostras, na amostra brasileira as provisões no período anterior sugerem que as provisões realizadas influenciam positivamente as despesas com provisões para créditos de liquidação duvidosa, o que é racional que as provisões possam levar a necessidade de incremento de perda para os créditos, quando deteriorado. $\mathrm{Na}$ amostra luso-espanhola, as provisões no período anterior sugerem que as provisões realizadas influenciam o componente discricionário das despesas, indicando que esse aspecto é considerado para novas constituições.

- A taxa média das operações, dada pela razão entre as receitas de operações de créditos e a carteira de crédito, com expectativa de relação positiva, teve confirmada essa expectativa, sugere que a remuneração média das operações, relaciona-se com a provisão, indicando que as taxas brasileiras assumem uma alta remuneração ao risco na concessão das operações de créditos efetivando-se o risco e a necessidade da 
constituição das provisões para créditos de liquidação duvidosa, não sendo significativa na amostra luso-espanhola, o que pode ser avaliado pela relação entre níveis de risco e taxa de juros entre os sistemas financeiros.

- A variável que analisa a relação da atividade econômica com as despesas com provisão teve sinal positivo, indicando que a intensificação econômica e movimentação da carteira, base das despesas, relaciona-se positivamente com a constituição das despesas.

- A variável que caracteriza a carteira indicou uma relação positiva para constituição de provisão nas operações privadas na amostra brasileira e negativa na luso-espanhola. Efeito esse que pode ser atribuído a características dos créditos. 
Quadro 2 - Análise de sinais esperados e resultados.

\begin{tabular}{|c|c|c|c|c|}
\hline \multirow{2}{*}{ Variável } & \multirow{2}{*}{ Comportamento Esperado } & \multicolumn{3}{|c|}{ Sinal dos Resultados } \\
\hline & & Esperado & Brasil & $\begin{array}{l}\text { Portugal- } \\
\text { Espanha }\end{array}$ \\
\hline$\triangle L O A N_{\mathrm{i}, \mathrm{t}}$ & $\begin{array}{l}\text { O aumento na carteira de operações de } \\
\text { créditos está positivamente relacionado ao } \\
\text { aumento das despesas de provisão para } \\
\text { créditos de liquidação duvidosa. }\end{array}$ & $(+)$ & $(+)^{*}$ & $(+)^{*}$ \\
\hline $\mathrm{NPL}_{\mathrm{i}, \mathrm{t}-1}$ & $\begin{array}{l}\text { O nível de operações vencidas, do período } \\
\text { anterior, deve estar positivamente } \\
\text { relacionado com a constituição da provisão } \\
\text { no período, pois a baixa qualidade dos } \\
\text { créditos motiva maiores níveis de provisão } \\
\text { para créditos de liquidação duvidosa. }\end{array}$ & $(+)$ & $(+)$ & $(+)$ \\
\hline$\triangle N P L_{\mathrm{i}, \mathrm{t}-1}$ & $\begin{array}{l}\text { Assim como no saldo da provisão anterior, a } \\
\text { variação no nível de operações vencidas, } \\
\text { deve estar positivamente relacionada com a } \\
\text { constituição da provisão no período, pois a } \\
\text { baixa qualidade dos créditos motiva maiores } \\
\text { níveis de provisão para créditos de } \\
\text { liquidação duvidosa. }\end{array}$ & $(+)$ & $(+)$ & $(+)$ \\
\hline$L L A_{\mathrm{i}, \mathrm{t}-1}$ & $\begin{array}{l}\text { A provisão do período anterior pode ter } \\
\text { influência na constituição em novas } \\
\text { considerando o aumento da deterioração, ou } \\
\text { ainda pode relacionar-se uma redução } \\
\text { discricionária. }\end{array}$ & $(+/-)$ & $(+)$ & $(-)^{*}$ \\
\hline$I N T_{\mathrm{i}, \mathrm{t}}$ & $\begin{array}{l}\text { Espera-se sinal positivo relacionada a taxa } \\
\text { média das operações de créditos, em função } \\
\text { da razão da razão do aumento da carteira e } \\
\text { seu retorno. }\end{array}$ & $(+)$ & $(-)$ & $(+)^{*}$ \\
\hline$G D P_{\mathrm{t}}$ & $\begin{array}{l}\text { A variável de análise de atividade } \\
\text { econômica, PIB espera-se uma relação } \\
\text { positiva quando do PIB positivo, haja vista a } \\
\text { relação de mais recursos disponíveis e mais } \\
\text { operações. }\end{array}$ & $(+/-)$ & $(+)^{*}$ & $(+)$ \\
\hline$T Y P_{\text {it }}$ & $\begin{array}{l}\text { Não há sinal esperado para o vetor tipo das } \\
\text { operações, divididas entre privado, público } \\
\text { e estrangeiro. }\end{array}$ & $(+/-)$ & $(+)^{*}$ & $(-)^{*}$ \\
\hline
\end{tabular}

Onde: (+) significa que a variável explicativa em questão se mostrou positivamente relacionada com a variável dependente; (-) significa que a variável explicativa em questão se mostrou negativamente relacionada variável dependente; (*) significa que há relação identificada pelo sinal, mas a relação não é significativa.

Onde: $\triangle L O A N_{\mathrm{i}, \mathrm{t}}$ : variação no valor do saldo da carteira de crédito; $\mathrm{NPL}_{\mathrm{i}, \mathrm{t}-\mathrm{1}}$ : saldo dos créditos vencidos e não pagos; $\triangle N P L_{\mathrm{i}, \mathrm{t}-1}$ : variação no valor dos empréstimos vencidos e não pagos; $L L A_{\mathrm{i}, \mathrm{t}-1}$ : saldo acumulado da provisão para créditos de liquidação duvidosa; $I N T_{\mathrm{i}, \mathrm{t}}$ taxa de juros implícita média da carteira de crédito, correspondente à razão entre as receitas de operações de créditos e o saldo médio da carteira; $G D P_{\mathrm{t}}$ : taxa de variação no Produto Interno Bruto; $T Y P_{\text {it: }}$ vetor das variáveis de controle que representam as proporções dos créditos distribuídas entre o setor público (PUB), setor privado (PRV) e não residentes (NRES), escalonado pelo total de ativos.

Fonte: Dados da pesquisa. 
As amostras tiveram como resultado de relação de significância para as variáveis explicativas: a) $\triangle L O A N_{i_{\mu} t}$ não significativa em ambas as amostras; b) $\left(N P L_{i, t-1}\right)$ significativa em ambas amostras; c) $\left(\triangle N P L_{i, t-1}\right)$ significativa em ambas amostras; d) $\left(L L A_{i, t-1}\right)$ significativa na amostra brasileira; e) (INT $\left.T_{i, t}\right)$ significativa na amostra brasileira e não significativa na amostra luso-espanhola; f) $\left(G D P_{i, t}\right)$ significativa na amostra luso-espanhola; g) $\left(T Y P_{i, t}\right)$ não significativa em ambas as amostras. 
Tabela 10 - Resumo comparativo dos resultados - Amostras brasileiros e luso-espanholas - Modelo (1).

$$
\begin{aligned}
L L P_{\mathrm{i}, t}=\beta_{0}+\beta_{\mathrm{i}} & +\beta_{1} \Delta L O A N_{\mathrm{i}, t}+\beta_{2} N P L_{\mathrm{i}, \mathrm{t}-1}+\beta_{\mathrm{a}} \Delta N P L_{\mathrm{i}, \mathrm{t}}+\beta_{4} L L A_{\mathrm{i}, \mathrm{t}-1}+\beta_{5} I N T_{\mathrm{i}, \mathrm{t}}+\beta_{6} G D P_{\mathrm{t}}+\psi_{1} \\
& <T Y P_{\mathrm{i}, \mathrm{t}}>+\varepsilon_{\mathrm{it}}
\end{aligned}
$$

\section{LS - Ordinary}

\begin{tabular}{lrrr}
\hline \multicolumn{1}{c}{ Variable } & \multicolumn{3}{c}{ Brasil } \\
\hline \multicolumn{2}{c}{ Coefficient } & \multicolumn{1}{c}{ t-Statistic } & \multicolumn{1}{c}{ Prob. } \\
\hline$\Delta L O A N_{\mathrm{i}, \mathrm{t}}$ & 0,017877 & 1,292658 & 0,1973 \\
$\mathrm{NPL}_{\mathrm{i}, \mathrm{t}-1}$ & 0,300387 & 6,47832 & 0,0000 \\
$\Delta N P L_{\mathrm{i}, \mathrm{t}-1}$ & 0,08749 & 1,732675 & 0,0843 \\
$L L A_{\mathrm{i}, \mathrm{t}-1}$ & 0,091481 & 2,039289 & 0,0424 \\
$I N T_{\mathrm{i}, \mathrm{t}}$ & $-0,037531$ & $-4,171022$ & 0,0000 \\
$G D P_{\mathrm{t}}$ & 26200,96 & 1,601739 & 0,1104 \\
$T Y P_{\text {it }}$ & 0,001208 & 0,919901 & 0,3585 \\
\hline & & & \\
\hline R-squared & 0,52177 & & \\
Adjusted R-squared & 0,46453 & & \\
F-statistic & 9,115487 & & \\
Prob(F-statistic) & 0,000000 & & \\
\hline
\end{tabular}

\begin{tabular}{lrrr}
\hline \multicolumn{1}{c}{ Variable } & \multicolumn{2}{c}{ Portugal-Espanha } \\
\hline$\Delta L O A N_{\mathrm{i}, \mathrm{t}}$ & Coefficient & t-Statistic & Prob. \\
$N \mathrm{~L}_{\mathrm{i}, \mathrm{t}-\mathrm{t}}$ & 0,013409 & 1,384988 & 0,1674 \\
$\Delta N P L_{\mathrm{i}, \mathrm{t}-\mathrm{t}}$ & 0,062258 & 2,521593 & 0,0124 \\
$L L A_{\mathrm{i}, \mathrm{t}-\mathrm{t}}$ & 0,131723 & 2,852767 & 0,0047 \\
$I N T_{\mathrm{i}, \mathrm{t}}$ & $-0,052201$ & $-1,632389$ & 0,1040 \\
$G D P_{\mathrm{t}}$ & 0,00408 & 0,293868 & 0,7691 \\
$T Y P_{\mathrm{it}}$ & $7.930,07$ & 1,759524 & 0,0799 \\
& $-0,000577$ & $-0,465217$ & 0,6422 \\
\hline R-squared & & & \\
Adjusted R-squared & 0,301254 & & \\
F-statistic & 0,216271 & \\
Prob(F-statistic) & 3,544890 & \\
\hline
\end{tabular}

Onde: $\triangle L O A N_{\mathrm{i}, \mathrm{t}}$ : variação no valor do saldo da carteira de crédito; $\mathrm{NPL}_{\mathrm{i}, \mathrm{t}-1}$ : saldo dos créditos vencidos e não pagos; $\triangle N P L_{\mathrm{i}, \mathrm{t}-1}$ : variação no valor dos empréstimos vencidos e não pagos; $L L A_{\mathrm{i}, \mathrm{t}-1}$ : saldo acumulado da provisão para créditos de liquidação duvidosa; $I N T_{\mathrm{i}, \mathrm{t}}$ taxa de juros implícita média da carteira de crédito, correspondente à razão entre as receitas de operações de créditos e o saldo médio da carteira; $G D P_{\mathrm{t}}$ : taxa de variação no Produto Interno Bruto; $T Y P_{\text {it: }}$ vetor das variáveis de controle que representam as proporções dos créditos distribuídas entre o setor público (PUB), setor privado (PRV) e não residentes (NRES), escalonado pelo total de ativos.

Fonte: Dados da pesquisa. 
Os resultados da significância global do modelo, por meio do teste (F) confirmam a significância em ambos os casos, analisando a hipótese nula de que os coeficientes estimados pela regressão são iguais a zero. Os resultados de $(9,115487)$ e $(3,544890)$, com p-value de $(0,00000)$ e $(0,00000)$, rejeita-se a hipótese nula, ou seja, as variações observadas nas despesas de provisão para créditos de liquidação duvidosa, em ambos os sistemas financeiros, decorrem das alterações das variáveis explicativas e não ocorrem, apenas, da variação do termo residual.

O coeficiente de determinação $\left(\mathrm{R}^{2}\right.$ ajustado) $(0,46453)$ e $(0,216271)$ indica que as variáveis explanatórias utilizadas explicam 46,4\% e 21,72\% das despesas de provisão para créditos de liquidação duvidosa nos sistemas financeiros analisados. Os resíduos de 54,6\% e $78,38 \%$ são utilizados como proxy para o componente discricionário das despesas de provisão, variável dependente no segundo estágio, resultados indicam que o componente discricionário das despesas é utilizado para gerenciamento de gerenciamento de resultados.

Por meio da análise dos resultados dos coeficientes e da estatística (t) da regressão confirmamos a relação positiva esperada da variação do saldo das operações de créditos $\left(\triangle L O A N_{i, t}\right)$ com a variável dependente nas amostras brasileiras e luso-espanholas, mostrandose consistentes com estudos anteriores e expectativa em relação aos componentes das despesas com provisão para créditos de liquidação duvidosa, entretanto, a variável não se mostrou significativa. $\mathrm{O}$ saldo das operações de créditos vencidas $\left(N P L_{i, t-1}\right)$ foi a variável mais significativa do modelo, indicando forte influência nas despesas com provisão. Os coeficientes indicam que nos sistemas financeiros as operações de créditos vencidas pressionam as despesas, o que é absolutamente racional e coerente com os normativos contábeis aplicáveis a constituição das provisões. As operações em inadimplência têm sua deterioração potencializada com o passar do tempo, dessa forma, a confirmação dessa tendência leva a intensificação das provisões. Sendo consistente com para ambas as amostras.

A estatística (t) de $(6,478320),(2,521593)$ e, com p-value de $(0,0000)$ e $(0,01240)$, respectivamente para as amostras brasileiras e luso-espanholas, evidenciam a variável $\left(N P L_{i, t-1}\right)$ das maiores dado o poder de explicação no modelo, e do comportamento das despesas com provisão. A variável é positivamente relacionada com a despesa, pela baixa qualidade dos créditos que requerem provisões. As variações das operações vencidas $\left(\triangle N P L_{i, t-1}\right)$ são significativas em ambas as amostras e com sinal positivo, e ratificam a influência nas despesas pelo mesmo aspecto mencionado sobre a variável saldo das operações vencidas. As normas aplicáveis as instituições financeiras consideram as operações de 
créditos vencidas com fortes características em relação à efetivação de perda, dessa forma, os resultados nos dois sistemas financeiros são consistentes com a indicação das provisões esperadas pelos critérios de mensuração previstos nos normativos. A variável que representa a variação das operações vencidas é a segunda variável mais significativa.

A provisão no período anterior com estatística $(\mathrm{t})$ de $(2,039289)$ e $(-1,632389)$ e $p$ value de $(0,04240)$ e $(0,10400)$, respectivamente, para amostras brasileiras e luso-espanholas, tem peculiar resultado pelo efeito do sinal que para a amostra brasileira foi positivo, analisa-se que seja efeito do aumento da deterioração. O resultado da amostra luso-espanhola com sinal negativo, mas não significativa, é entendido como efeito de limitador de provisões dado pela administração para constituição de novas provisões no período pelo nível elevado de provisões, assim uma perspectiva de escolha discricionária na formação das despesas com provisão, não foi significativa na amostra luso-espanhola indicando menor influência de gerenciamento de resultado dado o fator provisões acumuladas no período anterior.

A taxa média das operações foi significativa na amostra brasileira e não significante para a luso-espanhola, mas com sinal positivo, isso efeito das taxas de juros nas economias brasileira e europeia. As operações de créditos no Brasil possuem níveis muito elevados os quais possuem influência na formação da carteira e no perfil de risco, as taxas no cenário luso-espanhol são menores e tem por isso é era esperado a relação de significância brasileira e o oposto no caso português-espanhol. A relação da atividade econômica dada pelo PIB $(G D P)$ teve em ambas as amostras resultados similares, com relação positiva; contudo, significante apenas na amostra luso-espanhola, indicando que a atividade econômica causa incremento nas despesas de provisão, visto a esperada movimentação da carteira.

A variável vetor de controle $\left(T Y P_{i, t}\right)$, não significativa, e com influência negativa na amostra luso-espanhola e positiva na brasileira. Mas indicando que a carteira brasileira tem níveis mais elevados de provisão nas operações de créditos no setor privado e as operações de créditos luso-espanholas menor nível.

\subsection{Testes do modelo de segundo estágio}

Assim como aplicado para o modelo de primeiro estágio (1), para garantir a robustez ao modelo foram realizados os mesmos testes para consistência dos resultados no modelo de segundo estágio (2). Visando verificar a estacionariedade das séries temporais, foram realizados os testes de raízes unitárias e os testes Dickey-Fuller Aumentado (ADF) e de Phillips-Perron (PP). 
A hipótese nula do teste ADF e do teste PP é de que as séries analisadas possuem raízes unitárias. As estatísticas calculadas pelo teste ADF e pelo teste PP, respectivamente das amostras de Brasil e Portugal-Espanha, rejeitam a hipótese nula. Os resultados comprovam, estatisticamente, que as séries temporais analisadas são estacionárias, assim, sinalizando a robustez do modelo (1).

Tabela 11 - Teste Raiz Unitária - Modelo (2).

\begin{tabular}{|c|c|c|c|c|}
\hline \multicolumn{5}{|c|}{ Brasil } \\
\hline Variáveis & ADF & Prob. & PP & Prob. \\
\hline$D P C L D d_{\mathrm{i}, \mathrm{t}}$ & 127.071 & 0.0000 & 151.804 & 0.0000 \\
\hline $\operatorname{LnA} t_{\mathrm{i}, \mathrm{t}}$ & 122.494 & 0.0000 & 117.298 & 0.0000 \\
\hline$L L a j_{\mathrm{i}, \mathrm{t}}$ & 118.899 & 0.0000 & 151.219 & 0.0000 \\
\hline \multicolumn{5}{|c|}{ Portugal-Espanha } \\
\hline Variáveis & ADF & Prob. & $\mathbf{P P}$ & Prob. \\
\hline$D P C L D d_{\mathrm{i}, \mathrm{t}}$ & 104.534 & 0.0008 & 119.982 & 0.0000 \\
\hline $\operatorname{LnA} t_{\mathrm{i}, \mathrm{t}}$ & 115.171 & 0.0000 & 118.323 & 0.0000 \\
\hline$L L a j_{\mathrm{i}, \mathrm{t}}$ & 271.279 & 0.0000 & 296.843 & 0.0000 \\
\hline
\end{tabular}

Onde: $D P C L D d_{\mathrm{i}, \mathrm{t}}$ : componente discricionário das despesas de provisão para créditos de liquidação duvidosa, resíduos do modelo de primeiro estágio; $L n A t_{\mathrm{i}, \mathrm{t}}$ : logaritmo natural dos ativos totais, variável representativa do porte das instituições financeiras; $L L a j_{\mathrm{i}, \mathrm{t}}$ : resultado ajustado pelas despesas com provisões, escalonado pelos ativos totais.

Fonte: Dados da pesquisa.

Para verificar a existência de autocorrelação, o que, na existência, constitui violação a uma das hipóteses de um modelo clássico de regressão linear, foi realizado o teste de DurbinWatson. A hipótese nula a ser testada é a de que os resíduos da regressão são autocorrelacionados. Os resultados da estatística dw $(1,909845)$ e $(1,687269)$, apresentados, rejeitam a hipótese de autocorrelação. Pelos resultados, assume-se que os estimadores podem ser considerados como melhores estimadores lineares não enviesados. 
Tabela 12 - Teste Durbin Watson - Modelo (2).

\begin{tabular}{ccc}
\hline & & \multicolumn{2}{c}{ Países } \\
\cline { 2 - 3 } Teste & Brasil - Statistic & Portugal - Statistic \\
\hline Durbin Watson - Statistic & 1.836239 & 1.843136 \\
\hline
\end{tabular}

Fonte: Dados da pesquisa.

Para mitigar o risco de heterocedasticidade nos resíduos, as variáveis contábeis foram escalonadas na construção dos modelos, além do uso do método de erros padrões seccionais SUR (PCSE), que estima parâmetros robustos assumindo a presença de heterocedasticidade.

Com a realização do teste de ausência de autocorrelação, por meio do teste DurbinWatson foi afastada a hipótese de autocorrelação visto que as estatísticas das amostras indicaram não autocorrelação para amostra brasileira e inconclusiva para amostra lusoespanhola.

Para a avaliação do risco de multicolinearidade foi realizado o teste de inflação de variância entre as variáveis independentes, sugerido por Gujarati e Porter (2011), por meio do FIV apurados a partir das regressões.

Tabela 13 - Resultados dos testes de inflação entre as variáveis - Modelo (1).

\begin{tabular}{|c|c|c|}
\hline \multirow{2}{*}{ Variáveis } & \multicolumn{2}{|c|}{ Países } \\
\hline & Brasil - VIF & Portugal-Espanha - VIF \\
\hline$D P C L D d_{\mathrm{i}, \mathrm{t}}$ & 1,458366 & 1,296299 \\
\hline $\operatorname{Ln} A t_{\mathrm{i}, \mathrm{t}}$ & 1,225714 & 1,099090 \\
\hline$L L a j_{\mathrm{i}, \mathrm{t}}$ & 1,724039 & 1,352292 \\
\hline
\end{tabular}

Onde: $D P C L D d_{\mathrm{i}, \mathrm{t}}$ : componente discricionário das despesas de provisão para créditos de liquidação duvidosa, resíduos do modelo de primeiro estágio; $\operatorname{LnA} t_{\mathrm{i}, \mathrm{t}}$ : logaritmo natural dos ativos totais, variável representativa do porte das instituições financeiras; $L L a j_{\mathrm{i}, \mathrm{t}}$ : resultado ajustado pelas despesas com provisões, escalonado pelos ativos totais.

Fonte: Dados da pesquisa.

Haja vista que conforme Gujarati e Porter (2011), têm-se o comprometimento dos resultados em função da multicolinearidade quando o fator for maior que 10, os resultados afastam os problemas relacionados a multicolinearidade. 


\subsection{Análise dos resultados estimados Modelo (2) - Brasil e Portugal}

O componente discricionário das despesas de provisão para créditos de liquidação duvidosa $\left(D P C L D d_{i, t}\right)$ é utilizado como variável dependente no modelo (2), tendo como objetivo analisar as hipóteses da pesquisa.

A primeira hipótese da pesquisa é de que se tem uma relação positiva entre as despesas com provisão para créditos de liquidação duvidosa e os resultados das instituições financeiras, esperando um sinal positivo da variável explicativa no modelo. Tal hipótese é analisada por meio da relação existente entre o componente discricionário das despesas de provisão para créditos de liquidação duvidosa $\left(D P C L D d_{i, t}\right)$ e o resultado ajustado pelas provisões para créditos de liquidação duvidosa $\left(L L a j_{i, t}\right)$. Assim, a segunda hipótese, de que há o gerenciamento de gerenciamento através das despesas com provisão para créditos de liquidação duvidosa, será analisada pela significância da relação entre o resultado e o componente discricionário, indicando a utilização com propósito de gerenciar resultado. 
Tabela 14 - Resultados Modelo (2) - Amostras brasileiras e luso-espanholas.

\begin{tabular}{|c|c|c|c|}
\hline \multicolumn{4}{|c|}{$D P C L D d_{i, t}=\beta_{0}+\beta_{1} L L a j_{i, t}+\beta_{2} L n A t_{i, t}+\varepsilon_{i t}$} \\
\hline \multirow{2}{*}{ Variable } & \multicolumn{3}{|c|}{ Brasil } \\
\hline & Coefficient & t-Statistic & Prob. \\
\hline $\mathrm{C}$ & 2229557 & 1,480843 & 0,1216 \\
\hline$L L a j_{\mathrm{i}, \mathrm{t}}$ & 0,216265 & 6,291223 & 0,0000 \\
\hline $\operatorname{LnAt} t_{\mathrm{i}, \mathrm{t}}$ & 0,000319 & 0,340180 & 0,7022 \\
\hline R-squared & 0,147742 & & \\
\hline Adjusted R-squared & 0,063807 & & \\
\hline F-statistic & 1,760201 & & \\
\hline Prob(F-statistic) & 0,014815 & & \\
\hline \multirow{2}{*}{ Variable } & \multicolumn{3}{|c|}{ Portugal-Espanha } \\
\hline & Coefficient & t-Statistic & Prob. \\
\hline $\mathrm{C}$ & 907698,2 & 1,513562 & 0,1315 \\
\hline$L L a j_{\mathrm{i}, \mathrm{t}}$ & 0,073897 & 3,212174 & 0,0015 \\
\hline $\operatorname{LnAt} t_{\mathrm{i}, \mathrm{t}}$ & $-0,000333$ & $-1,500969$ & 0,1348 \\
\hline R-squared & 0,076868 & & \\
\hline Adjusted R-squared & 0 & & \\
\hline F-statistic & 0,859182 & & \\
\hline Prob(F-statistic) & 0,648790 & & \\
\hline
\end{tabular}

$D P C L D d_{\mathrm{i}, \mathrm{t}}$ : componente discricionário das despesas de provisão para créditos de liquidação duvidosa, resíduos do modelo de primeiro estágio; $L n A t_{\mathrm{i}, \mathrm{t}}$ : logaritmo natural dos ativos totais, variável representativa do porte das instituições financeiras; $L L a j \mathrm{j}, \mathrm{t}$ : resultado ajustado pelas despesas com provisões, escalonado pelos ativos totais.

Fonte: Dados da pesquisa.

A análise do coeficiente de determinação $\left(R^{2}\right)$ na amostra brasileira foi $(0,147742)$ demonstrou que a regressão explica $14,77 \%$ do componente discricionário das despesas de provisão para créditos de liquidação duvidosa, e na amostra luso-espanhola foi de $(0,076868)$, explicando 7,68\% do componente. É relevante enfatizar que o modelo de regressão em dois estágios absorve toda a heterogeneidade dos dados transversais, dessa forma, o coeficiente de determinação é baixo. Não obstante, conforme Gujarati e Porter (2011), o pesquisador deve preocupar-se mais com a relevância lógica ou teórica das variáveis explanatórias em relação à variável dependente e em sua significância estatística. 
No teste (F) de significância global, a estatística encontrada de (1,760201) e $(0,859182)$, com p-value de $(0,014815)$ e $(0,648790)$, rejeitando-se a hipótese nula de que todos os coeficientes são iguais a zero, na amostra brasileira.

As estatísticas (t) das regressões para as amostras do Brasil e Portugal-Espanha com coeficientes de $(6,582736)$ e $(3,212174)$, com p-value $(0,00000)$ e $(0,0015)$, e sinal positivo do coeficiente da variável $\left(L L a j_{i, t}\right)$, em relação ao componente discricionário são consistentes com a indicação de gerenciamento de resultado, tendo como comportamento de aumento das despesas com provisão quando o resultado é mais elevado e redução das despesas quando o resultado é baixo. A variável $\left(L n A t_{i, t}\right)$ representativa do porte das instituições financeiras com estatísticas (t) de $(0,382778)$ e $(-1,500969)$, com p-value de $(0,70220)$ e $(0,1348)$, tendo sinal positivo nas instituições financeiras brasileiras e negativo nas luso-espanholas, para a variável de controle não há um sinal esperado, em pesquisas anteriores como, por exemplo, a de Zendersky (2005), indica que há uma maior representação nas despesas de provisões em instituições financeiras de menor porte, o autor afirma que a análise deve ser cuidadosa, pois, em uma análise superficial pode levar a conclusões distorcidas.

Dessa forma, dado os resultados observamos que há evidência de gerenciamento de resultados em ambos os sistemas financeiros, contudo, é possível afirmar que há mais fortes indicações de maior nível de gerenciamento de resultado no Brasil, no período e amostra analisada, haja vista os maiores coeficientes das variáveis dependentes e maior relevância das mesmas, no mesmo sentido o maior p-value das variáveis e $\left(\mathrm{R}^{2}\right)$ do modelo reforçam a indicação de maior nível de gerenciamento de resultado no Brasil comparativamente a Portugal-Espanha.

\subsection{Procedimentos de robustez segundo estágio}

Com o objetivo de mitigar o risco de heterocedasticidade nos resíduos, as variáveis contábeis foram escalonadas na construção dos modelos. E ainda, fez-se uso do método de erros padrões seccionais SUR (PCSE), que estima parâmetros robustos assumindo a presença de heterocedasticidade e realizada a análise comparativa. 
Tabela 15 - Resultados - Modelo (2) - Amostras brasileiras e luso-espanholas SUR (PCSE).

$$
D P C L D d_{i, t}=\beta_{0}+\beta_{1} L L a j_{i, t}+\beta_{2} L n A t_{i, t}+\varepsilon_{i t}
$$

\begin{tabular}{|c|c|c|c|}
\hline LS - SUR (PCSE) & & & \\
\hline \multirow{2}{*}{ Variable } & \multicolumn{3}{|c|}{ Brasil } \\
\hline & Coefficient & t-Statistic & Prob. \\
\hline $\mathrm{C}$ & 2229557 & 1,480843 & 0,1398 \\
\hline$L L a j_{\mathrm{i}, \mathrm{t}}$ & 0,216265 & 6,291223 & 0,0000 \\
\hline $\operatorname{Ln} A t_{\mathrm{i}, \mathrm{t}}$ & 0,000319 & 0,354018 & 0,72360 \\
\hline R-squared & 0,147742 & & \\
\hline Adjusted R-squared & 0,063807 & & \\
\hline F-statistic & 1,760201 & & \\
\hline Prob(F-statistic) & 0,014815 & & \\
\hline
\end{tabular}

\begin{tabular}{lrrr}
\hline \multirow{2}{*}{ Variable } & \multicolumn{3}{c}{ Portugal-Espanha } \\
\cline { 2 - 4 } & \multicolumn{1}{c}{ Coefficient } & t-Statistic & Prob. \\
\hline C & 907698,2 & 1,369178 & 0,1723 \\
LLaji, & 0,073897 & 2,080177 & 0,0386 \\
LnAt $\mathrm{j}_{\mathrm{i}, \mathrm{t}}$ & $-0,000333$ & $-2,092596$ & 0,0375 \\
\hline & & & \\
\hline R-squared & 0,076868 & \\
Adjusted R-squared & 0 & & \\
F-statistic & 0,859182 & \\
Prob(F-statistic) & 0,648790 & & \\
\hline
\end{tabular}

$D P C L D d_{\mathrm{i}, \mathrm{t}}$ : componente discricionário das despesas de provisão para créditos de liquidação duvidosa, resíduos do modelo de primeiro estágio; $L n A t_{\mathrm{i}, \mathrm{t}}$ : logaritmo natural dos ativos totais, variável representativa do porte das instituições financeiras; $L L a j_{\mathrm{i}, \mathrm{t}}$ : resultado ajustado pelas despesas com provisões, escalonado pelos ativos totais.

Fonte: Dados da pesquisa.

Analisando os resultados comparativamente ao que foi observado aos resultados pelo método de erros padrões seccionais SUR (PCSE), a significância geral resultado do teste (F) manteve-se a mesma. As variáveis independentes mantiveram as relações bem como significância. 


\section{CONSIDERAÇÕES FINAIS}

A presente pesquisa teve como norte o gerenciamento de resultados em instituições financeiras que atuam no sistema financeiro brasileiro e luso-espanhol. As instituições financeiras possuem papel importante no sistema financeiro em geral, e a Contabilidade é um dos instrumentos para que os interessados possam acompanhar o desempenho do segmento. $\mathrm{O}$ estudo do gerenciamento de resultado no sistema financeiro é peculiarmente delicado, tendo vista os potenciais impactos que problemas em bancos podem acarretar na economia de um país.

O processo de elaboração das informações contábeis está naturalmente sujeito a influência do julgamento de seus responsáveis, o gerenciamento de resultado aproveita a oportunidade dos julgamentos discricionários que precisam ser empregados para determinadas mensurações. As instituições financeiras, por sua característica de intermediador financeiro, têm sua estrutura de ativos formada, principalmente, por operações de créditos, para o qual é requerida a aplicação de critérios para obtenção do valor efetivamente realizável. Nesse cenário além dos critérios objetivos, os quais são observáveis, há uma parcela que requer julgamento no processo de mensuração, conhecida com parcela discricionária, que é utilizada como recurso para gerenciar os resultados e é apontada como principal acumulação discricionária das instituições financeiras. A relevância das operações de créditos e, consequente, a constituição das provisões para créditos de liquidação duvidosa, são percebidas pela participação no total de ativos nos sistemas financeiros objeto da pesquisa.

Dada a relevância do tema e com finalidade de contribuir com as pesquisas sistematizadas sobre gerenciamento de resultado, delimitou-se o objeto de estudo, assim conceituando gerenciamento de resultados, a partir das pesquisas anteriores e as abordagens dadas ao assunto. O estudo buscou avaliar a existência de relação entre as despesas com provisão para operações de créditos e o resultado das instituições financeiras, e, em tal cenário, obter indicação que a relação se caracteriza como gerenciamento de resultado.

Com intuito de contribuir com o estudo de gerenciamento de resultados em instituições financeiras a pesquisa avaliou as hipóteses citadas, nos sistemas financeiros brasileiro e luso-espanhol. O agrupamento dos sistemas financeiros português e espanhol se deu pelas características comuns entre os países, bem como pelo relacionamento significativo entre as nações. Adicionalmente, buscou-se equilibrar a quantidade de instituições utilizadas nas amostras. 
O estudo foi realizado com a abordagem de acumulações (accruals), as quais são consideradas bons elementos de predição. Baseado em pesquisas anteriores, foi utilizado um modelo utilizado em estudos tendo como objeto instituições financeiras. O modelo foi simplificado por meio de variáveis que se mostraram significativas e com poder explicativo. Foi utilizada como metodologia a estimação em dois estágios. Buscou-se estruturar o método de acordo com as hipóteses consideradas para a pesquisa que envolvem o julgamento por meio da discricionariedade das provisões.

No processo da pesquisa fez-se, em um primeiro momento, a identificação dos componentes das acumulações. A análise do coeficiente de determinação $\left(R^{2}\right)$ mostrou que a as variáveis explanatórias da parcela não discricionária explicam 52,17\% e 30,12\%, respectivamente, na amostra brasileira e luso-espanhola da composição das despesas de provisão para créditos de liquidação duvidosa, sendo o resíduo utilizado como proxy de componente discricionário no segundo estágio do método. Assim como em outras pesquisas, os resultados indicam que a maior parte das despesas com provisões para créditos de liquidação duvidosa são explicadas pela parcela discricionária e pelo termo residual da regressão, resultado que indica comportamento de gerenciamento de resultado.

Os resíduos obtidos no primeiro estágio da regressão foram utilizados como proxy do componente discricionário das despesas com provisão para créditos de liquidação duvidosa das operações de créditos e de acordo com os efeitos decorrentes das características da carteira analisado em relação às variáveis explanatórias do segundo estágio da regressão buscando as evidências necessárias paras as hipóteses da pesquisa.

Os resultados, conforme as análises, demonstraram uma relação entre o componente discricionário das despesas de provisão para créditos de liquidação duvidosa e o resultado ajustado, sendo estatisticamente significativo na amostra brasileira. Como limitação, se destaca o resultado do teste " $\mathrm{f}$ " do segundo estágio da amostra luso-espanhola, que apesar das variáveis manterem os sinais esperados, o modelo não foi significativo. Sobre a ótica das hipóteses da pesquisa, têm-se que quando o resultado aumenta, os componentes discricionários das despesas de provisão para créditos de liquidação duvidosa também aumentam. E igualmente, quando o resultado diminui, as despesas com provisões são reduzidas, esse cenário sendo válido para as instituições financeiras brasileiras e lusoespanholas, as quais demonstram significância e os mesmos sinais de coeficientes, indicando os procedimentos. Os resultados indicam a aceitação das hipóteses, havendo relação positiva entre as despesas com provisão para créditos de liquidação duvidosa e os resultados das 
instituições financeiras brasileiras e luso-espanholas e a utilização das despesas com provisão para créditos de liquidação duvidosa para gerenciamento de resultado.

Dessa forma, as instituições financeiras analisadas brasileiras e luso-espanholas utilizam as despesas para gerenciar resultados, utilizando o componente discricionário, os julgamentos na mensuração das despesas de provisão para créditos de liquidação duvidosa.

As regressões foram realizadas utilizando a metodologia de análise de dados em painel, método o qual os resultados levam em consideração as características individuais e os fatores atribuídos aos períodos sob análise. O método permitiu avaliar a relação positiva entre o componente discricionário das despesas de provisão com provisão para créditos de liquidação duvidosa e o resultado e relação entre essas duas variáveis ao longo do tempo. Adicionalmente, os dados em painel oferecem dados mais informativos, maior variabilidade, menos colinearidade entre as variáveis e mais graus de liberdade. Além dos testes para garantir as premissas de melhor estimador linear não enviesado. Foi utilizado para mitigar o risco de heterocedasticidade nos resíduos o método de erros padrões seccionais SUR (PCSE), que estima parâmetros robustos, tendo resultados semelhantes ao método ordinário comparativamente.

Assim, o método contribui para análise temporal das observações, instituições financeiras, no período analisado. Os sinais observados são consistentes com a indicação de suavização dos resultados, haja vista a característica sugerir a redução de variabilidade.

Como limitação do trabalho, vale ressaltar o período analisado (2009 a 2014) e a quantidade (30 brasileiras e 31 luso-espanholas) de instituições incluídas, mas buscou-se agregar a maior quantidade de observações possíveis dos sistemas financeiras brasileiro, português e espanhol - aspecto dificultado pela ausência da totalidade de dados para inclusão de instituições financeiras no modelo, e, com objetivo de equilibrar a quantidade de instituições em cada sistema financeiro, restringiu-se a quantidade de instituições financeiras brasileiras, para as quais existem mais informações disponíveis.

Os resultados da pesquisa foram consistentes com estudos anteriores e agregou com a comparação entre os resultados das instituições financeiras brasileiras e luso-espanholas, tendo resultados semelhantes e consistentes com a expectativa metodológica, obtendo indicação positiva para aceitar as hipóteses sugerindo gerenciamento de resultados por meio das despesas com provisão para créditos de liquidação duvidosa das operações de créditos.

Por fim, a existência de gerenciamento de resultado como medida utilizada para atingir objetivos esperados pela Administração compromete a apresentação fidedigna das informações contábeis, enviesando as informações disponibilizadas aos usuários o que pode 
ensejar em uma conclusão derivada de informações com estimativas que não refletem a estimativa mais adequada para o resultado apresentado e por consequência comprometendo as decisões dos usuários. A pesquisa teve como limitação o período de abrangência da amostra, entre 2009 e 2014.

A pesquisa teve por norte a análise de gerenciamento de resultados em sistemas bancários distintos, tendo abrangência limitada ao gerenciamento de resultado por meio das provisões para créditos de liquidação duvidosa. Como oportunidades de pesquisas futuras se poderá pesquisar as motivações nos ambientes diferentes e os objetivos com a aplicação dos procedimentos de gerenciamento de resultado, com destaque para a possibilidade de estudo da utilização de outros componentes entre os sistemas bancários para fins de gerenciamento de resultados. 


\section{REFERÊNCIAS}

AHMED, A. C.; TAKEDA, A. THOMAS, S. Bank loan loss provisions: a reexamination of capital management, earnings management and signaling effects. Journal of Accounting and Economics. v. 28, n. 1, p. 1-25, nov. 1999. Disponível em: <http://papers.ssrn.com/sol3/papers.cfm?abstract_id=84188>. Acesso em: $1^{\text {oo }}$ out. 2015.

AMAT, O.; GOWTHORPE, C. Creative accounting: nature, incidence and ethical issues. Journal of Economic Literature, abr. 2004. Disponível em <http://www.econ.upf.edu/docs/papers/downloads/749.pdf>. Acesso em: $1^{\mathrm{o}}$ out. 2015.

ARAÚJO, S. M. A. de. Impacto da aplicação das Normas Internacionais de Contabilidade nas empresas do PSI 20. 2010. Dissertação (Mestrado em Contabilidade, Fiscalidade e Finanças Empresariais) - Universidade Técnica de Lisboa, Instituo Superior de Economia e Gestão (ISEG), Lisboa, 2010. Disponível em: <http://www.repository.utl.pt/bitstream/10400.5/2384/1/Tese\%20Sandra.pdf>. Acesso em: $1^{\circ}$ out. 2015.

BANCO DA ESPANHA - BDE. Circular n. 4, de 22 de dezembro de 2004. Normas de informação financeira pública. Disponível em: <www.bde.es/f/webbde/SJU/normativa/circulares/4.2004.pdf>. Acesso em: $1^{\text {o }}$ out. 2015.

BEATTY, A. L.; CHAMBERLAIN, S. L.; MAGLIOLO, J. Managing financial reports of commercial banks: the influence of taxes, regulatory capital, and earnings. Journal of Accounting Research, v. 33, n. 2, p. 231-261, 1995. Disponível em: <http://fic.wharton.upenn.edu/fic/papers/94/9402.pdf>. Acesso em: 1º out. 2015.

; KE, B.; PETRONI, K. R. Earnings management to avoid earnings declines across publicly and privately held banks. The Accounting Review, v. 77, n. 3, p. 547-570, jul. 2002. Disponível em: <https://www.researchgate.net/publication/228142843_Earnings_Management_to_Avoid_De clines_Across_Publicly_and_Privately_Held_Banks>. Acesso em: 1ºut. 2015. 
BEAVER, W. H.; ENGEL, E. E. Discretionary behavior with respect to allowances for loan losses and the behavior of security prices. Journal of Accounting and Economics, v. 22, ns. 1-3, p. 177-206, jan. $1996 . \quad$ Disponível em: <http://www.sciencedirect.com/science/article/pii/S0165410196004284>. Acesso em: $1^{\text {o }}$ out. 2015.

BENEISH, M. D. Earnings management: a perspective. Abr. 2001. Disponível em: <http://papers.ssrn.com/sol3/papers.cfm?abstract_id=269625>. Acesso em: 5 out. 2015.

BERNARD, V. L.; SKINNER, D. J. What motivates managers' choice of discretionary accruals? Journal of Accounting and Economics, v. 22, ns. 1-3, p. 313-325, ago./dez. 1996. Disponível em: <http://www.sciencedirect.com/science/article/pii/S0165410196004314>. Acesso em: $1^{\circ}$ out. 2015.

BURGSTHALER, D., DICHEV I. Earnings management to avoid earnings decrease and losses. Journal of Accounting and Economics, v. 24, n. 1, p. 99-126, dez. 1997. Disponível em: <http://www.cfapubs.org/doi/pdf/10.2469/dig.v28.n3.302>. Acesso em: $1^{\text {o }}$ out. 2015.

CAMFFERMAN, K. The emergence of the 'incurred loss' model for credit losses in IAS 39. Fev. 2014. Disponível em: <https://www.researchgate.net/publication/256056848_The_Emergence_of_the_'Incurred_Lo ss'_Model_for_Credit_Losses_in_IAS_39>.Acesso em: 02 fev. 2014.

CHENG, Q.; WARFIELD, T. D.; YE, M. Equity incentives and earnings management: evidence from a regulated industry. Jan. 2009. Disponível em: <http://papers.ssrn.com/sol3/papers.cfm?abstract_id=1326558>. Acesso em: 02 fev. 2014.

COHEN, L. J.; CORNETT, M. M.; MARCUS, A. J.; TEHRANIAN, H. Bank earnings management and tail risk during the financial crisis. Journal of Money, Credit and Banking, v. 46, n. 1, p. 171-197, 2014. Disponível em: <http://onlinelibrary.wiley.com/doi/10.1111/jmcb.12101/pdf>. Acesso em: $1^{\text {o }}$ out. 2015. 
CONSELHO MONETÁRIO NACIONAL - CMN. Resolução n. 1.748, de 31 de agosto de 1990. Altera e consolida critérios para inscrição de valores nas contas de créditos em liquidação e provisão para créditos de liquidação duvidosa. Brasília, 1990. Disponível em: <http://www.bcb.gov.br/pre/normativos/busca/downloadNormativo.asp?arquivo=/Lists/Norm ativos/Attachments/44638/Res_1748_v1_O.pdf>. Acesso em: 13 jun. 2015.

Resolução n. 2.682, de 21 de dezembro de 1999. Dispõe sobre critérios de classificação das operações de crédito e regras para constituição de provisão para créditos de liquidação duvidosa. Brasília, 1999. Disponível em: <http://www.bcb.gov.br/pre/normativos/busca/downloadNormativo.asp?arquivo=/Lists/Norm ativos/Attachments/44961/Res_2682_v2_P.pdf>. Acesso em: 13 jun.2015.

Resolução n. 3.786, de 24 de setembro de 2009. Dispõe sobre a elaboração e a divulgação de demonstrações financeiras consolidadas com base no padrão contábil internacional emitido pelo International Accounting Standards Board (IASB). Brasília, 2009.

Disponível

em:

<http://www.bcb.gov.br/pre/normativos/busca/downloadNormativo.asp?arquivo=/Lists/Norm ativos/Attachments/47513/Res_3786_v1_O.pdf>. Acesso em: 13 jun. 2015.

CORNETT, M. M.; McNUTT, J. J.; TEHRANIAN, H. Corporate governance and earnings management at large U.S. bank holding companies. Journal of Corporate Finance, v. 15, n. 4, p. 412-430, 2009. Disponível em: <http://www.sciencedirect.com/science/article/pii/S092911990900039X>. Acesso em: 13 jun. 2015.

DANTAS, J. A. Auditoria em instituições financeiras: determinantes de qualidade no mercado brasileiro. 2012. 173 f. Tese (Doutorado em Ciências Contábeis) - Programa MultiInstitucional e Inter-Regional de Pós-Graduação em Ciências Contábeis. Universidade de Brasília/Universidade Federal da Paraíba/Universidade Federal do Rio Grande do Norte. Brasília, $2012 . \quad$ Disponível em: <http://repositorio.unb.br/bitstream/10482/11751/1/2012_JoseAlvesDantas.pdf>. Acesso em: $1^{\circ}$ out. 2015. 
; MEDEIROS, O. R.; GALDI, F. C.; COSTA, F. M. Gerenciamento de resultados em bancos com uso de TVM: validação de modelo de dois estágios. Revista Contabilidade \& Finanças - USP, v. 24, n. 61, p. 37-64. jan./abr. 2013. Disponível em: <http://www.revistas.usp.br/rcf/article/view/58649/61732>. Acesso em: $1^{\text {o }}$ out. 2015.

; MEDEIROS, O. R.; LUSTOSA, P. R. B. O papel de variáveis econômicas e atributos da carteira na estimação das provisões discricionárias para perdas em operações de crédito nos bancos brasileiros. BBR - Brazilian Business Review, Vitória, v. 10, n. 4, p. 69-95, out./dez. 2013. Disponível em: <http://www.redalyc.org/articulo.oa?id=123029355003>. Acesso em: $1^{\mathrm{o}}$ out. 2015.

DeANGELO, L. E. Accounting numbers as market valuation substitutes: a study of management buyouts of public stockholders. The Accounting Review, v. 61, n. 3, p. 400420, jul. $1986 . \quad$ Disponível em: <http://www.jstor.org/stable/247149?seq=1\#page_scan_tab_contents>. Acesso em: $1^{\mathrm{o}}$ out. 2015.

DECHOW, P. M.; HUTTON, A. P.; KIM, J. H.; SLOAN, R. G. Detecting earnings management: a new approach. Journal of Accounting Research. v. 50, n. 2, p. 275-334, maio 2012. Disponível em: <http://onlinelibrary.wiley.com/doi/10.1111/j.1475679X.2012.00449.x/pdf>. Acesso em: $1^{\text {o }}$ out. 2015.

; SKINNER, D. J. Earnings management: reconciling the views of accounting academics, practitioners and regulators. Accounting Horizons Sarasota. v. 14, n. 2, p. 235 250, jun. 2000. Disponível em: <http://faculty.chicagobooth.edu/douglas.skinner/research/papers/3358109.pdf >. Acesso em: $1^{\mathrm{o}}$ out. 2015.

; WEILI, G.; SCHRAND, C. Understanding earnings quality: a review of the proxies: their determinants and their consequences. Journal of Accounting and Economics, v. 50, p. 344-401, ago. 2010. Disponível em: <http://papers.ssrn.com/sol3/papers.cfm?abstract_id=1485858>. Acesso em: $1^{\text {o }}$ out. 2015. 
FEDERAL FINANCIAL INSTITUTIONS EXAMINATION COUNCIL - FFIEC. Policy statement on allowance for loan and lease losses methodologies and documentation for banks and savings institutions. Federal Register. Jul. 2001. Disponível em: <http://www.federalreserve.gov/boarddocs/srletters/2006/SR0617a1.pdf>. Acesso em: $1^{\circ}$ out. 2015.

FREYRE, G. Casa-grande \& senzala: formação da família brasileira sob o regime de economia patriarcal. 51. ed. São Paulo: Global, 2006.

FUJI, A. H. Gerenciamento de resultados contábeis no âmbito das instituições financeiras atuantes no Brasil. 2004. Dissertação (Mestrado em Ciências Contábeis) Faculdade de Economia, Administração e Contabilidade. Universidade de São Paulo. São Paulo, 2004. Disponível em: <http://www.teses.usp.br/teses/disponiveis/12/12136/tde17032008-124153/pt-br.php>. Acesso em: $1^{\circ}$ out. 2015.

GABRIEL, F.; CORRAR, L. J. C. Gerenciamento de resultados e de capital no sistema bancário brasileiro - Uma investigação empírica nas aplicações em títulos e valores mobiliários. Revista de Contabilidade do Mestrado em Ciências Contábeis da UERJ (online), Rio de Janeiro, v. 15, n. 2, p. 50-62, maio/ago. 2010. Disponível em: <http://www.epublicacoes.uerj.br/index.php/rcmccuerj/article/view/5499/3997>. Acesso em: $1^{\text {o }}$ out. 2015.

GALDI, F. C.; PEREIRA, L. M. Fair value dos derivativos e gerenciamento de resultados nos bancos brasileiros: existe manipulação? In: $7^{\circ}$ Encontro Brasileiro de Finanças. Anais... São Paulo: $2007 . \quad$ IBMEC, Disponível em: <http://www.fucape.br/_public/producao_cientifica/2/galdi_fair\%20value.pdf>. Acesso em: $1^{\circ}$ out. 2015.

GERAKOS, J. Discussion of detecting earnings management: a new approuch. Journal of Accounting Research, v. 0, n. 0, p. 1-13, 2012. Disponível em: $<$ http://faculty.chicagobooth.edu/joseph.gerakos/pdfs/gerakos_em_discussion.pdf $>$. Acesso em: $1^{\circ}$ out. 2015. 
GOMES, A. L. P. Gerenciamento de resultados em instituições financeiras no Brasil - De 2001 a 2012. 2014. 50 f. Dissertação (Mestrado em Economia e Finanças) - Escola de Economia de São Paulo. Fundação Getúlio Vargas. São Paulo, 2014. Disponível em: <https://bibliotecadigital.fgv.br/dspace/bitstream/handle/10438/11477/Disserta\%C3\%A7\%C3 \%A3o\%20-\%20Earning\%20Management.pdf?sequence=3\&isAllowed $=\mathrm{y}>$. Acesso em: $1^{\circ}$ out. 2015.

GOUlaRT, A. M. C. Gerenciamento de Resultados Contábeis em instituições financeiras no Brasil. 2007. 219 f. Tese (Doutorado em Ciências Contábeis) - Faculdade de Economia, Administração e Contabilidade. Departamento de Contabilidade e Atuaria. Universidade de São Paulo. São Paulo, 2007. Disponível em: <http://www.teses.usp.br/teses/disponiveis/12/12136/tde-17032008-124153/pt-br.php>. Acesso em: $1^{\circ}$ out. 2015.

GUJARATI, D. N; PORTER, D. C. Econometria básica. 5.ed. São Paulo: Saraiva, 2011.

HEALY, P. M. The effect of bonus schemes on accounting decisions. Journal of Accounting and Economics, v. 7, p. 85-107, 1985. Disponível em: <http://econ.au.dk/fileadmin/Economics_Business/Education/Summer_University_2012/6308 _Advanced_Financial_Accounting/Advanced_Financial_Accounting/4/Healy_JAE_1985.pdf >. Acesso em: $1^{\circ}$ out. 2015.

; WHALEN, J. M. A review of the earnings management literature and its implications for standard setting. Accounting Horizons, v. 13, n. 4, p. 365-383, dez. 1999. Disponível em: <http://fisher.osu.edu/ young.53/Healy-Wahlen>. Acesso em: $1^{\circ}$ out. 2015.

IMPRENSA NACIONAL. Casa da Moeda. Aviso n. 01/2005 do Banco de Portugal. 28 fev. 2005. Disponível em: $<$ http://www.bportugal.pt/sibap/application/app1/aviso.asp?PVer=P\&PNum=1/2005>. Acesso em: $1^{\text {o }}$ out. 2015.

Casa da Moeda. Aviso n. 03/1995 do Banco de Portugal. 30 jun. 1995. Disponível em: 〈http://www.bportugal.pt/sibap/application/app1/docs1/avisos/textos/3-95a.pdf>. Acesso em: $1^{\text {o }}$ out. 2015. 
Casa da Moeda. Carta Circular n. 02/2014/DSP do Banco de Portugal. Critérios de referência - Mensuração da imparidade da carteira de crédito e respectivas divulgações. 2014. Disponível em: <http://www.bportugal.pt/sibap/application/app1/docs1/circulares/textos/2-2014-DSP.pdf>. Acesso em: $1^{\circ}$ out. 2015.

INCHAUSTI. B. G. Instituciones e intereses en conflicto ante la regulación contable internacional: el caso del sector financiero español. Revista de Contabilidad, Barcelona, v. 17, n. 2, p. 143-152, jan. 2014. Disponível em: <http://www.redalyc.org/articulo.oa?id=359733647005>. Acesso em: $1^{\text {o }}$ out. 2015.

JIN, L.; MYERS, S. C. R2 around the world: new theory and new tests. Journal of Financial Economics, $\quad$ v. 79, p. 257-292, 2006. Disponível em: <http://www.sciencedirect.com/science/article/pii/S0304405X05001194>. Acesso em: 1ºut. 2015.

JONES, J. J. Earnings management during import relief investigations. Journal of Accounting Research, v. 29, n. 2, p. 193-228, 1991. Disponível em: <http://www.jstor.org/stable/2491047>. Acesso em: $1^{\text {o }}$ out. 2015.

KANAGARETNAM, K.; LOBO, G. J; MATHIEU, R. Managerial incentives for income smoothing through bank loan loss provision. 2001. Disponível em: <https://www.researchgate.net/publication/5157567_'Managerial_Incentives_for_Income_Sm oothing_Through_Bank_Loan_Loss_Provisions>. Acesso em: 13 jun. 2015.

; LIM, C. Y.; LOBO, G. J. Auditor reputation and earnings management: international evidence from the banking industry. Journal of Banking and Finance, v. 34, p. 2318-2327, jan. 2010. Disponível em: <http://papers.ssrn.com/sol3/papers.cfm?abstract_id=1568866>. Acesso em: 13 jun. 2015. 
MARCONDES, D. A. Disciplina de mercado e as acumulações contábeis discricionárias. 2008. 150 f. Tese (Doutorado em Ciências Contábeis) - Departamento de Contabilidade e Atuária. Faculdade de Economia, Administração e Contabilidade. Universidade de São Paulo. São Paulo, 2008. Disponível em: <http://www.teses.usp.br/teses/disponiveis/12/12136/tde19012009-111828/pt-br.php>. Acesso em: $1^{\circ}$ out. 2015.

MARTINEZ, A. L. “Gerenciamento" dos Resultados Contábeis: Estudo Empírico das Companhias Abertas Brasileiras. 2001. Tese (Doutorado em Ciências Contábeis) Faculdade de Economia, Administração e Contabilidade. Departamento de Contabilidade e Atuária. Universidade de São Paulo. São Paulo, 2001. Disponível em: <http://www.teses.usp.br/teses/disponiveis/12/12136/tde-14052002-110538/pt-br.php>. Acesso em: $1^{\circ}$ out. 2015.

MAta, E. M. VAlÉrio, N. The Concise Economic History of Portugal. A Comprehensive Guide. Coimbra: Almedina, 2011.

McNICHOLS, M.; WILSON, G. P. Evidence of earnings management from the provision for bad debts. Journal of Accounting Research, v. 26, Supplement, p. 1-31, 1988. Disponível em: <http://www.jstor.org/stable/2491176?seq=1\#page_scan_tab_contents>. Acesso em: 19 out. 2014.

MENDES, C. A.; RODRIGUES, L. L. Estudo de práticas de earnings management nas empresas portuguesas cotadas em bolsa: identificação de alisamento de resultados e seus factores explicativos. Revista de Estudos Politécnicos, v. 3, ns. 5-6, p. 145-173, 2006. Disponível em: <http://www.scielo.mec.pt/pdf/tek/n5-6/3n5-6a08.pdf〉. Acesso em: 13 out. 2014.

NIYAMA, J. K.; GOMES, A. L. O. Contabilidade de instituições financeiras. 4. ed. São Paulo: Atlas, 2012.

PARFET, W. U. Accounting subjectivity and earnings management: a preparer perspective. Accounting Horizons, v. 14, n. 4. p. 481-488, dez. 2000. Disponível em: <http://aaajournals.org/doi/abs/10.2308/acch.2000.14.4.481>. Acesso em: 19 out. 2014. 
PARK, Y. W.; SHIN, H-H. Board composition and earnings management in Canada. Journal of Corporate Finance, v. 10, n. 3, p. 431-457, 2004. Disponível em: <http://www.sciencedirect.com/science/article/pii/S0929119903000257>. Acesso em: 19 out. 2014.

PÉRIGNON, C.; DENG, Z. Y.; WANG, Z. J. Do banks overstate their value-at-risk? Journal of Banking \& Finance, v. 32, n. 5, p. 783-794, maio 2008. Disponível em: <http://www.sciencedirect.com/science/article/pii/S0378426607002336>. Acesso em: 19 out. 2014.

RODRIGUES, A. Gerenciamento dos resultados contábeis através de receitas e despesas não operacionais: estudo empírico das Companhias "nível 1" - Bovespa. Sociedade, Contabilidade e Gestão, Rio de Janeiro, v. 2, n. 1, 2007. Disponível em: <http://www.atena.org.br/revista/ojs-2.2.3-08/index.php/ufrj/article/viewFile/573/562>. Acesso em: $1^{\circ}$ out. 2014.

PINHO, P. S.; MARTINS, N. C. Determinants of portuguese bank's provisioning policies: discretionary behaviour of generic and specific allwances. Journal of Money, Investment and Banking, $\quad$ v. 10.2009 .2 Disponível em: <http://www.novasbe.unl.pt/pt/component/zoo/item/determinants-of-portuguese-banksprovisioning-policies-discretionary-behaviour-of-generic-and-specific-allowances>. Acesso em: $1^{\circ}$ out. 2014.

SANTOS, A.; GRATERON, I. R. G. Contabilidade criativa e responsabilidade dos auditores. Revista Contabilidade \& Finanças - USP, São Paulo, n. 32, p. 7-22, maio/ago. 2003. Disponível em: <http://www.scielo.br/pdf/rcf/v14n32/v14n32a01.pdf>. Acesso em: $1^{\circ}$ out. 2014.

SCOTT, W. Financial accounting theory. Toronto: Pearson Education, 2003. 
SCHIPPER, K. Commentary on earnings management. Accounting Horizons, v. 3, n. 4, p. 91-102, dez. $1989 . \quad$ Disponível em: <http://connection.ebscohost.com/c/articles/4816073/commentary-earnings-management>. Acesso em: $1^{\circ}$ out. 2014.

SHRIEVES, R. E.; DAHL, D. Discretionary accounting and the behavior of japanese banks under financial duress. Journal of Banking and Finance, v. 27, n. 7, p. 1219-1243, jul. 2003. Disponível em: <http://www.sciencedirect.com/science/article/pii/S0378426602002522>. Acesso em: $1^{\circ}$ out. 2014.

SILVA, M. F. S. G. O caminho da Ibéria. Dissertação (Mestrado em Estratégia) - Instituto Superior de Ciências Sociais e Políticas. Universidade Técnica de Lisboa. Lisboa, 2011. Disponível em: <http://www.repository.utl.pt/bitstream/10400.5/4014/1/O\%20CAMINHO\%20DA\%20IB\%C 3\%89RIA.pdf>. Acesso em: $1^{\circ}$ out. 2014.

SPOHR, Jonas. Essayson earnings management. Ekonomi Och Samhälle, n.153, 2005.

WONG, H. S. Equity incentives and earnings management: evidence from the banking industry. 2011. Dissertação (Mestrado em Ciências Contábeis) - Erasmus University in Rotterdam, 2011. Disponível em: https://www.google.com.br/url?sa=t\&rct=j\&q=\&esrc=s\&source=web\&cd=1\&ved=0ahUKEw iChua4sJvLAhWFgJAKHSoxAzAQFggcMAA\&url=http\%3A\%2F\%2Fthesis.eur.nl\%2Fpub \%2F9042\%2FM865-

Wong_196647.docx\&usg=AFQjCNEhJ5ry0of5yxjNTRlhj5AFPwKIJg\&sig2=VzGiDgm92bo txt505MrgeA\&bvm=bv.115339255,d.Y2I\&cad=rja>. Acesso em: $1^{\circ}$ out. 2014.

XAVIER, P. H. M.. Gerenciamento de resultados por bancos comerciais no Brasil. 2007. 139 p. Tese (Doutorado em Ciências Contábeis) - Faculdade de Economia, Administração e Contabilidade. Departamento de Contabilidade e Atuária. Universidade de São Pualo, São Paulo, 2007. Disponível em: <http://www.teses.usp.br/teses/disponiveis/12/12136/tde30012008-120921/pt-br.php>. Acesso em: $1^{\text {o }}$ out. 2014.

ZENDERSKY, H. C. Gerenciamento de resultados em instituições financeiras no Brasil 2000 a 2004. 2005. Dissertação (Mestrado em Ciências Contábeis) - Programa Multiinstitucional e Inter-Regional de Pós-Graduação em Ciências Contábeis. Universidade 
de Brasília/Universidade Federal da Paraíba/Universidade Federal do Rio Grande do Norte. Brasília, 2005. Disponível em: 〈http://cca.unb.br/images/dissert_mest/mest_dissert_076.pdf>. Acesso em: $1^{\circ}$ out. 2014.

\section{Bibliografia consultada:}

BRASIL. Lei n. 4.595, de 31 de dezembro de 1964. Dispõe sobre a política e as instituições monetárias bancárias e creditícias, cria o Conselho Monetário Nacional e dá outras providências. $\quad$ Brasília, $1964 . \quad$ Disponível em <http://www.planalto.gov.br/ccivil_03/leis/L4595.htm>. Acesso em: 13 jun. 2015.

BUCKMASTER, D. Income soothing in accounting and business literature prior to 1954. The Accounting Historians Journal. v. 19, n. 2, p. 147-173, dez. 1992. Disponível em: <http://www.jstor.org/stable/40698086?seq=1\#page_scan_tab_contents>. Acesso em: $1^{\circ}$ out. 2014.

DECHOW, P. M.; DICHEV, I. D. The quality of accruals and earnings: the role of accrual estimation errors. The Accounting Review. v. 77, n. 4, p. 35-59, 2002. Disponível em: $<$ http://www.jstor.org/stable/3203324?seq=1\#page_scan_tab_contents $>$. Acesso em: $1^{\mathrm{o}}$ out. 2014.

DIAS, O. A. Divulgação do Risco de Crédito antes e após a crise financeira de 2008. Dissertação (Mestre em Contabilidade e Finanças) - Instituto Politécnico de Setúbal. Escola Superior de Ciências Empresariais. Setúbal, 2014. Disponível em: <http://comum.rcaap.pt/bitstream/10400.26/7339/1/DISSERTACAO\%20OSVALDO\%20DI AS.pdf >. Acesso em: $1^{\circ}$ out. 2014.

LOUIS, H. Earnings management and the market performance of acquiring firms. Journal of Financial Economics, v. 74, p. 121-148, 2002. Disponível em: <http://papers.ssrn.com/sol3/papers.cfm?abstract_id=336180>. Acesso em: $1^{\text {o }}$ out. 2014.

MAIA, A. I. S. "Earnings Management" na banca portuguesa - Os casos do BCP, BES e BPI. 2014. Dissertação (Mestrado em Economia) - Faculdade de Economia. Universidade do 
Porto. Porto, 2014. Disponível em: <https://repositorioaberto.up.pt/bitstream/10216/76609/2/102324.pdf>. Acesso em: $1^{\text {o }}$ out. 2014.

NIYAMA, J. K. Constituição da provisão para créditos de liquidação duvidosa de bancos e demais instituições financeiras - Principais alterações introduzidas pelo Conselho Monetário Nacional e o efeito nas demonstrações financeiras. ConTexto, Porto Alegre, v. 1, n. 1, 2001.

Indicadores econômico-financeiros dos bancos brasileiros: impactos Associados aos Padrões Contábeis do IASB e do BCB. In: $13^{\circ}$ Congresso USP de Controladoria e Contabilidade - Desafios e Tendências da Normatização Contábil. Anais eletrônicos... São Paulo, 25 a 26 de julho de 2013. Disponível em: <http://www.congressousp.fipecafi.org/web/artigos132013/150.pdf> Acesso em: 07 fev. 2014.

; GOMES, A. L. O. Contabilidade de instituições financeiras. 2 ed. São Paulo: Atlas, 2002.

; __ Contabilidade de instituições financeiras. 3. ed. São Paulo: Atlas, 2009.

PIRES, A. Sistema de normalização contabilística do POC ao SNC. Lisboa: Publisher Team, 2009.

SEIDLER, J. C. O.; DECOURT, R. F. Gerenciamento de resultados: análise bibliométrica dos estudos científicos nacionais no período de 2006 a 2013. Revista Recont Registro Contábil, Maceió, v. 5, n. 2, p. 21-48, mai/ago. 2014. Disponível em: <http://www.seer.ufal.br/index.php/registrocontabil/article/view/1121/pdf_23>. Acesso em: $1^{\circ}$ out. 2014. 
APÊNDICES 


\section{APÊNDICE A - LISTA DOS BANCOS UTILIZADOS NA PESQUISA}
a) Brasil
1) ABC-BRASIL
2) ALFA
3) BANCOOB
4) BANESTES
5) BANRISUL
6) $\mathrm{BB}$
7) BCO DA AMAZONIA S.A.
8) BCO DAYCOVAL S.A
9) BCO RABOBANK INTL BRASIL S.A
10) BCO TOKYO-MITSUBISHI BM S.A.
11) $\mathrm{BIC}$
12) BMG
13) BNP PARIBAS
14) BRADESCO
15) BRB
16) BTG PACTUAL
17) CAIXA ECONOMICA FEDERAL
18) CITIBANK
19) DEUTSCHE
20) HSBC
21) ITAU
22) JPMORGANCHASE
23) MERCANTIL DO BRASIL
24) PANAMERICANO
25) PINE
26) SAFRA
27) SANTANDER
28) SOCIETE GENERALE
29) VOTORANTIM
30) CRÉDIT AGRICOLE BRASIL S.A

b) Portugal:

1) BANCO BPI

2) BANCO CARREGOSA

3) BANIF INV

4) BANIF SGPS 
5) BBVA

6) BES

7) BESI

8) BIG

9) BPN

10) $\mathrm{CBI}$

11) CGD

12) CRÉDITO AGRÍCOLA

13) DEUTSCHE BANK

14) INVEST

15) MILLENNIUM BCP

16) MONTEPIO

17) POPULAR

18) SANT CONSUMER

19) SANTANDER TOTTA SGPS

c) Espanha:

1) BANCA MARCH

2) BANCO BILBAO VIZCAYA ARGENTARIA

3) BANCO COOPERATIVO ESPAÑOL

4) BANCO DE SABADELL

5) BANCO POPULAR ESPAÑOL

6) BANCO SANTANDER

7) BANKINTER

8) BARCLAYS BANK

9) CAIXA BANK S.A.

10) DEUTSCHE BANK, S.A.E.

11) DEXIA SABADELL

12) SANTANDER CONSUMER FINANCE 


\section{APÊNDICE B - REPRESENTAÇÃO DA AMOSTRA NO SISTEMA FINANCEIRO}

Tabela B.1 - Representação da amostra no sistema financeiro.

\begin{tabular}{|c|c|c|c|}
\hline Ranking & Instituição & Ativo total (-) intermediação & $\%$ \\
\hline 1 & BANCO DO BRASIL & 1.075 .528 & \\
\hline 2 & ITAU & 1.013 .567 & \\
\hline 3 & CAIXA ECONOMICA FEDERAL & 968.564 & \\
\hline 4 & BRADESCO & 694.588 & \\
\hline 5 & SANTANDER & 590.120 & \\
\hline 6 & HSBC & 164.704 & \\
\hline 7 & BTG-PACTUAL & 127.759 & \\
\hline 8 & SAFRA & 122.480 & \\
\hline 9 & VOTORANTIM & 95.002 & \\
\hline 10 & CITIBANK & 57.659 & \\
\hline 11 & BANRISUL & 58.934 & \\
\hline 12 & BANCO DO NORDESTE DO BRASIL & 38.205 & \\
\hline 13 & BNP PARIBAS & 33.220 & \\
\hline 14 & JP MORGAN CHASE & 32.514 & \\
\hline 15 & DEUTSCHE & 27.509 & \\
\hline 16 & PAN & 25.558 & \\
\hline 17 & ABC-BRASIL & 20.745 & \\
\hline 18 & BANCOOB & 20.547 & \\
\hline 19 & SOCIETE GENERALE & 18.522 & \\
\hline 20 & BANCO DAYCOVAL S.A. & 18.214 & \\
\hline 21 & BMG & 17.012 & \\
\hline 22 & BANCO RABOBANK INTL BRASIL S.A. & 16.157 & \\
\hline 23 & $\mathrm{BIC}$ & 15.642 & \\
\hline 24 & BANESTES & 12.868 & \\
\hline 25 & ALFA & 14.699 & \\
\hline 26 & BANCO TOKYO-MITSUBISHI S.A. & 12.843 & \\
\hline 27 & BANCO DA AMAZÔNIA S.A. & 12.418 & \\
\hline 28 & MERCANTIL DO BRASIL & 12.328 & \\
\hline 29 & BRB & 11.930 & \\
\hline 30 & PINE & 10.404 & \\
\hline \multicolumn{2}{|c|}{ Total Ativo Amostra } & 5.340 .242 & \\
\hline \multicolumn{2}{|c|}{ Total Ativo Sistema Financeiro Nacional* } & 6.740 .448 & 79,23 \\
\hline \multicolumn{2}{|c|}{ Total Consolidado Bancário I (96 Instituições) } & 5.521 .264 & 96,72 \\
\hline
\end{tabular}

* Relatório 50 Maiores Bancos e o Consolidado do Sistema Financeiro Nacional (BACEN) - 31.12.2014. 


\section{APÊNDICE C - PROVISÃO PARA CRÉDITOS DE LIQUIDAÇÃO DUVIDOSA EM INSTITUIÇÕES FINANCEIRAS}

\section{Provisão para créditos de liquidação duvidosa em bancos portugueses}

O Banco de Portugal exerce a função de supervisor prudencial das instituições de crédito, das sociedades financeiras e das instituições de pagamento. Com vistas a assegurar a estabilidade, eficiência e solidez do sistema financeiro, cumprimento de regras de conduta e de prestação de informação aos clientes bancários, bem como garantir a segurança dos depósitos e dos depositantes e a proteção dos interesses dos clientes.

O Decreto-Lei n. 158, de 13 de julho de 2009, aprovou o Sistema de Normalização Contabilística (SNC), passando exigir aplicação das normas internacionais de contabilidade para entidades que tenham negociação de valores mobiliários. O Aviso do Banco de Portugal n. 01/2005 determina que se apliquem as normas internacionais de contabilidade na elaboração das demonstrações financeiras, quer em base individual, quer em base consolidada, para determinadas instituições financeiras.

Conforme Araújo (2010), as empresas portuguesas regiam-se pelo Decreto-Lei n. 47, de 07 de fevereiro de 1977, que aprovou o Plano Oficial de Contabilidade (POC) e criou a Comissão de Normalização Contabilística (CNC). O POC passou por alterações com a entrada de Portugal na Comunidade Econômica Europeia (atual União Europeia) em 1986, adaptando-se às diretivas comunitárias.

Para os bancos portugueses, por meio do Decreto-Lei n. 35, de 17 de fevereiro de 2005 e do Aviso n. 01/2005 do Banco de Portugal, as empresas portuguesas com títulos negociados nos mercados europeus são obrigadas a elaborar demonstrações consolidadas segundo as IFRS adotadas pela União Europeia a partir de 2005.

O aviso emitido pelo Banco de Portugal (equivalente ao Banco Central do Brasil BACEN) determina que as instituições financeiras devam elaborar as demonstrações financeiras em base individual e em base consolidada de acordo com as normas internacionais de contabilidade, sendo que em cada momento da adoção das normas, o normativo requer que na elaboração das demonstrações financeiras em base individual, sejam observadas orientações que não necessariamente estão previstas nas normas emitida pelo International Accounting Standards Board (IASB).

A seguir, tem-se os aspectos que o normativo português requer na elaboração das demonstrações financeiras individuais: 
$\mathrm{Na}$ valorização dos créditos a clientes e valores a receber de outros devedores (crédito e contas a receber) deve ser observado o seguinte:

a) $\mathrm{Na}$ data do reconhecimento inicial, os ativos financeiros são registados pelo valor nominal, não podendo, quer nessa data, quer em data de reconhecimento subsequente, ser incluídos em/reclassificados para as restantes categorias de ativos financeiros;

b) A componente de juros, incluindo a referente a eventuais prêmios/descontos, é objecto de evidenciação contábil individual nas respectivas contas de resultados;

c) As receitas são reconhecidos quando obtidos e distribuídos por períodos mensais, segundo a regra pro rata temporis, quando se trate de operações que produzam fluxos redituais ao longo de um período superior a um mês;

d) Sempre que aplicável, as comissões e custos externos imputáveis à contratação das operações subjacentes aos ativos incluídos nesta categoria deverão ser, igualmente, ao longo do período de vigência dos créditos;

e) $\mathrm{O}$ valor dos ativos incluídos nesta categoria deve ser objeto de correção, de acordo com critérios de rigor e prudência, por forma que reflitam, a todo o tempo, o seu valor realizável;

f) A correção não poderá ser inferior ao que for estabelecido por aviso do Banco de Portugal como quadro mínimo de referência para a constituição de provisões específicas e genéricas;

g) Para efeitos da constituição das provisões genéricas, será considerado o total do crédito concedido pela instituição, incluindo o representado por aceites, garantias e outros instrumentos de natureza análoga (Aviso n. 01/2005 - Banco de Portugal).

Conforme o exposto, é possível observar a existência de políticas estabelecidas pela autoridade reguladora das instituições financeiras portuguesas que divergem das políticas contábeis estabelecidas pelo (IASB). No que tange às operações de créditos (empréstimos), o reconhecimento de provisão para créditos de liquidação duvidosa dos empréstimos (imparidade) é feito por meio de níveis mínimos de provisionamento, considerando também aceites, garantias e outros instrumentos de natureza semelhante, divergindo da política contábil do IASB, o qual possui conceito de perda incorrida.

O Aviso n. 03/1995 do Banco de Portugal requer que as "sociedades financeiras" considerem provisões para:

a) Para risco específico de crédito;

b) Para riscos gerais de crédito;

c) Para risco-país;

d) Para imparidade em aplicações sobre instituições de crédito;

e) Para imparidade em títulos e em participações financeiras; e

f) Para imparidade em ativos não financeiros.

O normativo português requer que seja constituída provisão considerando a classificação dos créditos em classes de riscos, as quais, segundo o normativo refletem o escalonamento dos créditos e dos juros vencidos em função do período decorrido após o 
respectivo vencimento ou o período decorrido após a data em que tenha sido formalmente apresentada ao devedor a exigência da sua liquidação. Abaixo as classes e percentuais de provisão estabelecidas.

Tabela 16 - Classificação dos créditos em classes de riscos.

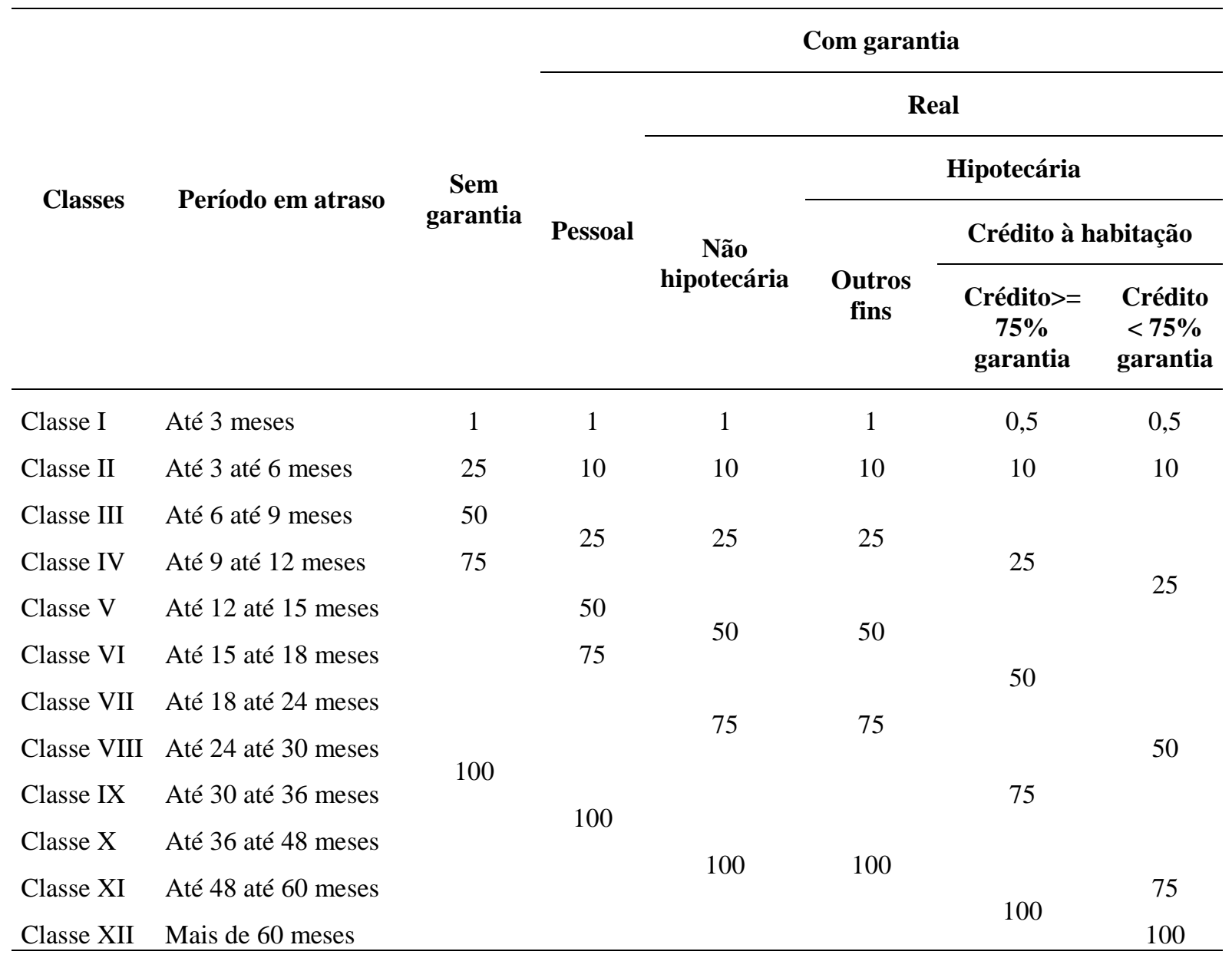

Fonte: Aviso n. 03/1995 do Banco de Portugal.

Dessa forma, as práticas contábeis utilizadas pelas instituições financeiras portuguesas, foram denominadas, conforme disposto no Aviso n. 01/2005 do Banco de Portugal de Normas Contábeis Ajustadas (NCA). A NCA prevê a utilização das normas emitidas pelo IASB, agregando os ajustes específicos previstos para as instituições reguladas.

A Carta Circular n. 02, de 26 de abril de 2014, trata dos critérios na mensuração da imparidade da carteira de crédito e respectivas divulgações, que constituem um referencial mínimo, para o tratamento contábil de operações específicas ou cumprimento de níveis mínimos de provisionamento. O Anexo I da carta-circular dá orientações quanto à metodologia de cálculo da imparidade da carteira de crédito, considerando: identificação dos indícios de imparidade; exposição individualmente significativa; exposições analisadas 
individualmente, exposições analisadas coletivamente; julgamentos, pressupostos e premissas; documentação (formalização) e divulgações.

Dessa forma, é possível observar os fatores subjetivos na determinação das premissas para mensuração da provisão para perdas, o que permite a aplicação de políticas com objetivo distinto ao de mensurar a melhor estimativa de perda para as operações de créditos das instituições financeiras.

\section{Provisão para créditos de liquidação duvidosa nos bancos espanhóis}

O Regulamento n. 1.606/2002 introduziu o uso obrigatório das normas internacionais na União Europeia (UE), incluindo o setor financeiro. Na Espanha a autoridade bancária é o Banco da Espanha (BDE), semelhante a estrutura portuguesa e brasileira, sendo o responsável pela supervisão das instituições financeiras, e reguladora contábil para as instituições financeiras. A Circular 4/2004 adapta a regulamentação ao setor financeiro para o IFRS estabelecendo a aplicação reservada as demonstrações financeiras consolidadas.

Para Inchausti (2014), o objetivo do regulador bancário é garantir a estabilidade e sobrevivência do sistema financeiro, enquanto os padrões IFRS se destinam a facilitar a tomada de decisões por parte dos investidores. Ainda conforme o autor, enquanto um objetiva tranquilizar os investidores, prevalecer a relevância da informação e transparência, para o outro, a prioridade é dada para a estabilidade nos números e medidas prudenciais relacionadas com o capital regulamentar. Na Espanha, conforme Inchausti (2014), tem havido um desvio de regras nacionais por meio das Circulares Banco da Espanha (BDE) para as demonstrações financeiras consolidadas e essas normas podem se distanciar das disposições do IFRS, em função do tratamento das disposições estabelecidas na Circular n. 04/2004. O regulador espanhol assim como no Brasil e Portugal estabelece critérios a serem observados em adição ao requerido nas disposições do IFRS para apuração de perdas em operações de créditos. Nesse sentido, a alteração da proposta em relação ao tratamento de provisões na carteira de crédito, incorpora estimativas de perdas esperadas, semelhantes as estimativas aplicadas no Brasil e em Portugal.

Conforme a Circular n. 04/2004 do Banco da Espanha, os instrumentos de dívida devem ser classificados de acordo com o risco de insolvência atribuível ao cliente ou transações em qualquer uma das seguintes classificações: 
Quadro 3 - Categorias dos riscos de insolvências.

\begin{tabular}{|l|c|}
\hline \multicolumn{1}{|c|}{ Classificação } & Subclasse de risco \\
\hline \multirow{2}{*}{ Normal } & Sem risco identificado \\
\cline { 2 - 2 } & Baixo Risco \\
\cline { 2 - 2 } & Médio-baixo risco \\
\cline { 2 - 2 } & Médio risco \\
\cline { 2 - 2 } & Médio-alto risco \\
\hline Risco inferior & Alto risco \\
\hline Duvidoso - Risco devido à inadimplência de seus clientes & - \\
\hline Duvidoso - Risco exceto inadimplência de clientes & - \\
\hline Risco inadimplente & - \\
\hline
\end{tabular}

Fonte: Adaptado de Circular n. 04/2004 - Banco da Espanha.

As operações classificadas como "Normal", incluem todos os instrumentos de dívida que não cumprem os requisitos para a classificação em outras categorias. As operações incluídas nesta categoria estão subdivididas, por sua vez, em subclasses de risco, em que:

a) Sem risco identificado - compreendem operações: com riscos de administrações públicas dos países da União Europeia, incluindo as decorrentes de acordos de recompra de dívida pública, as sociedades não financeiras públicas e as Administrações Centrais dos países classificados no grupo 1, para efeitos de riscopaís; ou aqueles apoiados por tais refinanciamento públicos direto ou indiretos através de agências governamentais com garantia ilimitada do mesmo; adiantamentos sobre pensões e salários para o mês seguinte quando o devedor for uma autoridade pública e ao mesmo tenham domicílio no Estado; segurados, garantidos ou refinanciadas por organismos públicos ou de empresas de países classificados no Grupo 1 (países da União Europeia, Noruega, Suíça, Islândia, Estados Unidos, Canadá, Japão, Austrália e Nova Zelândia), para efeitos de risco-país cuja atividade principal é o crédito de seguro ou garantia para cobrir parte; que estão em nome de instituições de crédito; que assegurar a plena, de suporte, explícita e incondicional garantia pessoal concedidos por instituições de créditos mencionadas acima e por sociedades de garantia mútua espanhóis que podem reivindicar primeira solicitação; riscos em nome dos fundos de garantia de depósitos, desde que sejam comparáveis por seu crédito para a qualidade da União Europeia; aqueles garantidos por depósitos em dinheiro ou ter garantia de FMI ações ou títulos de dívida emitidos pelo governo ou bancos, quando a exposição 
total seja igual ou inferior a $90 \%$ do valor de resgate de ações de instituições financeiras monetárias e o valor de mercado títulos recebidos como garantia.

b) Baixo risco - Compreende as seguintes operações: ativos para servir como garantia para operações de política monetária do Sistema Europeu de Bancos Centrais, exceto aqueles incluídos na categoria acima, as operações garantidas por habitações concluídas ou leasing, tais bens cuja exposição seja inferior a $80 \%$ do valor avaliado das habitações; os títulos de securitização de hipotecas comuns; operações cujo proprietário é empresa cuja dívida a longo prazo são classificados pelo menos como A para alguma agência de rating reconhecida; e títulos em moeda local emitidos por governos centrais dos países não classificados no grupo 1 .

c) Médio-baixo risco - Compreende operações de: arredamento financeiro e os riscos que têm uma segurança diferente do que as indicadas nos riscos enumerados nos itens acima, desde que o valor estimado dos ativos vendidos em leasing e totalmente cobertas a exposição total, e não estão incluídos em outras classes de risco.

d) Médio risco - Compreende os riscos para os residentes na Espanha ou em países dos grupos 1 e 2 para os efeitos do risco-país, não incluídos nas classes acima de risco, a menos que satisfaçam os critérios de classificação nas classes médio risco e alto risco.

e) Médio-alto risco - Compreende as operações compra de bens de consumo duráveis e de outros bens e serviços comuns de pessoas, não para uma atividade empresarial, exceto que eles são inscritas no Registro de Vendas a prazo de bens pessoais; riscos concedidos para o financiamento de terra para o setor imobiliário ou de construção ou desenvolvimento de propriedades de promoção, mesmo quando eles têm a garantia de tais ativos; e riscos com final devedores residentes em países em grupos de 3-6 excluídos para fins de cobertura do risco país, risco que não estão incluídos em outras classes. Exceto se satisfizerem os critérios para classificação em empréstimos de alto risco.

f) Alto risco - compreendem as operações saldos de cartões de crédito, descobertos e conta de crédito excedido, independentemente do proprietário, com exceção dos referidos em (i) e (ii) anteriores.

As operações classificadas com "Risco inferior" incluem todos os instrumentos de dívida e riscos contingentes que, sem cumprir os critérios para classificá-los individualmente como duvidosos ou com inadimplências. Esta categoria inclui, entre outros: operações dos clientes que fazem parte de grupos problemáticos (como moradores de uma determinada área 
geográfica a um nível inferior ao país, ou aqueles que pertencem a um determinado setor econômico que estão em dificuldades econômicas), para os quais as perdas globais superiores que correspondem às categorias descritas em operações anteriores.

As operações classificadas como "Duvidoso - Risco devido à inadimplência de seus clientes", incluem a quantidade total de instrumentos de dívida, seja qual for seu titular e garantia de ter qualquer valor devido do principal, juros ou taxas acordadas contratualmente, com mais de três meses de idade, a menos classifiquem como inadimplentes; e os riscos contingentes de realização da garantida.

As operações que se classificam como "Duvidoso - Risco exceto inadimplência de clientes" são instrumentos de dívida que incluem, vencidos ou não, em que, sem as circunstâncias, para classificá-los em categorias de inadimplentes ou duvidosos devido a pagamentos em atraso de clientes, de qualquer dúvida razoável sobre o seu reembolso total (capital e juros) que sejam contratualmente acordada nos termos; e riscos contingentes e compromissos contingentes não classificados como duvidosos devido à inadimplência de seus clientes pela entidade para a qual o pagamento é provável duvidosa.

Risco inadimplente, nesta categoria a quantidade de instrumentos de dívida estão incluídos, vencidos ou não, para aqueles após uma análise individual é considerada com recuperação remota e qualifica-se para baixa. Salvo prova em contrário, nesta categoria todas as dívidas, exceto as quantidades abrangidas pelos clientes com suficientes garantias efetivas que são declaradas em default para o registro que tenha sido declarado ou irá declarar a fase de liquidação incluiria ou submeter-se a uma deterioração significativa e irrecuperável de sua solvência, os saldos e as operações classificadas como de cobrança duvidosa devido a atrasos com mais de quatro anos.

Além da classificação das operações pelo risco de insolvência do cliente as operações de créditos possuem perdas mensuradas pelo risco em função do risco país.

Os instrumentos de dívida não mensurados ao valor justo através de ganhos e perdas e exposições a contingências, independentemente do cliente, são analisados para determinar o seu risco de crédito em razão do risco-país. Para estes fins, o risco país, o risco decorrente de clientes residentes num determinado país devido a outras do que o risco comercial normal. $\mathrm{O}$ risco-país compreende o risco soberano, risco de transferência e outros riscos decorrentes da atividade financeira internacional, conforme definido pela Circular 4/2004 do Banco da Espanha: 
a) Os riscos soberanos dos credores de Estados ou entidades garantidas por eles, como pode ser ineficaz ações legais contra o mutuário ou o último obrigado a pagar, por razões de soberania.

b) O risco de transferência é dos credores estrangeiros de um país enfrentando uma deficiência geral para lidar com suas dívidas, por falta de moeda ou moedas em que operam.

c) Os riscos restantes derivados da atividade financeira internacional são aqueles resultantes de qualquer uma das seguintes situações: guerra civil ou internacional, revolução, ou qualquer evento catastrófico semelhante.

A Circular 4/2004 dispõe ainda que as operações sejam alocadas de acordo com o país de residência do cliente no momento da análise inicial, exceto nos seguintes casos, quando eles são classificados da seguinte forma:

a) que são garantidos por residentes de outro país melhor colocado ou outros residentes na Espanha, pelo credor garantido, que incluem o fiador, desde que o grupo tenha capacidade suficiente para honrar seus compromissos financeiros.

b) Aqueles que têm garantia para a parte coberta, desde que a segurança seja suficiente, e o item coberto pela garantia são realizáveis na Espanha ou outro país no grupo 1, que é classificada no grupo de risco 1.

c) Riscos com filiais no exterior de uma entidade que é classificada de acordo com a situação no país de residência da sede das atividades.

Conforme mencionado anteriormente, as provisões possuem sua mensuração baseada em risco país, onde os instrumentos de dívida são classificados de acordo com seus grupos de risco-país, de 1-6 listados. Assim, as instituições conforme o regulamento espanhol deve fazer uma avaliação global do risco dos países para os quais operações imputadas de acordo com seu desenvolvimento econômico, enquadramento político, regulamentar e institucional, e capacidade e experiência de pagamento. Para o efeito, considera-se os seguintes indicadores para o país:

a) A experiência de pagamento, com um foco, se for caso, no cumprimento dos acordos de renegociação e pagamentos a serem feitos a instituições financeiras internacionais.

b) A situação financeira externa, especialmente tendo em conta os indicadores de dívida externa total, a dívida externa de curto prazo, a dívida em relação ao PIB e das exportações, e as reservas estrangeiras. 
c) A situação econômica, baseada principalmente em: i) Indicadores relativos ao orçamento, monetária e da balança de pagamentos agregados; ii) os indicadores relacionados com o crescimento econômico (nível de renda, as taxas de poupança ou investimento, o crescimento do PIB) e a vulnerabilidade (diversificação das exportações, dependência da ajuda).

d) Indicadores de Mercado; em particular, os ratings de crédito feitas por agências de rating de reconhecido prestígio, os preços de dívida no mercado secundário, o acesso aos mercados e é considerada a dívida e diferenciais de taxa de juros.

O regulamento espanhol classifica as operações nos grupos seguintes, tendo em conta a importância relativa dos indicadores citados anteriormente:

Quadro 4 - Grupos da classificação de operações.

\begin{tabular}{|c|l|}
\hline Grupo & \multicolumn{1}{c|}{ Componentes } \\
\hline 1 & União Europeia, Noruega, Suíça, Islândia, EUA, Canadá, Japão, Austrália e Nova Zelândia. \\
\hline 2 & $\begin{array}{l}\text { Neste grupo serão incluídas as operações com devedores finais residentes em países que, apesar } \\
\text { de baixo risco, não estão incluídos no grupo 1. }\end{array}$ \\
\hline 3 & $\begin{array}{l}\text { Este grupo inclui pelo menos transações finais devedores residentes em países com uma } \\
\text { deterioração macroeconômica significativa que é considerado susceptível de afetar a capacidade } \\
\text { do país de pagar }\end{array}$ \\
\hline 4 & $\begin{array}{l}\text { Este grupo irá incluir, pelo menos, as transações finais com devedores residentes em países com } \\
\text { profunda deterioração macroeconômica que é considerada seriamente afetar a capacidade do } \\
\text { país de pagar. }\end{array}$ \\
\hline 5 & $\begin{array}{l}\text { Este grupo transações com final devedores residentes em países com dificuldades prolongadas } \\
\text { ao serviço da dívida, considerada duvidosa se a recuperação será incluída. }\end{array}$ \\
\hline 6 & $\begin{array}{l}\text { Em operações onde a busca pela recuperação é considerada remota devido a circunstâncias } \\
\text { imputáveis ao país. Em qualquer caso, o grupo inclui transações com devedores finais residentes } \\
\text { em países que não reconhecem as suas dívidas ou não tem pagamentos de amortização e juros } \\
\text { por quatro anos. }\end{array}$ \\
\hline
\end{tabular}

Fonte: Adaptado de Circular n. 04/2004 - Banco da Espanha.

Os instrumentos de dívida e riscos contingentes classificados em grupos de 3-6, exceto excluídos de cobertura do risco-país, são classificados com a finalidade de estimar a imparidade por motivo de risco-país nas seguintes categorias:

a) Risco de risco-país abaixo do padrão: As operações classificadas nos grupos 3 e 4, a menos que as operações devem ser classificadas como duvidosos ou risco atribuível ao cliente. 
b) Em dúvida para risco país: Operações classificadas no grupo 5, contingentes e compromissos contingentes classificados no grupo 6, a menos que devidamente classificados como duvidosos ou risco com risco atribuível aos clientes.

c) Risco inadimplência risco-país: Operações classificadas no grupo 6, a menos que as transações devem ser classificadas como de risco não imputável ao cliente. Os instrumentos de dívida classificados nesta categoria serão baixados do ativo.

As instituições devem avaliar os ativos classificados como duvidosos por causa da inadimplência de seus clientes individualmente, especialmente as de montante significativo, levando em conta a idade dos valores não pagos, as garantias prestadas e a situação econômica do cliente e fiadores para estimar a cobertura deficiente.

Além disso, as instituições desenvolvem métodos para calcular a estimativa de perda coletiva para estes ativos, em que os montantes são determinados nos padrões de atraso. Para fazer isso, os bancos classificam seus ativos dependendo da idade das avaliações não pagas e as garantias existentes, manter bancos de dados, além de estatísticas históricas sobre a sua evolução e resultado.

O Banco da Espanha, com base na sua experiência e informações sobre o setor bancário espanhol, estimou os percentuais mínimos de cobertura. Os percentuais de cobertura incluídas nessas programações padrão levam em conta o valor do dinheiro no tempo. As entidades devem aplicar, no mínimo, esses percentuais na estimativa de subsídios específicos para avaliação perdas coletivas de transações registradas em nome de residentes espanhóis e em entidades subsidiárias estrangeiras. O Banco da Espanha atualiza regularmente estas estimativas, de acordo com a evolução dos dados do setor, isso por meio da atualização da circular.

As taxas a seguir são aplicáveis a todos ativos, exceto os classificados como "sem risco identificável", ou que tenham garantias que cubram o risco:

Tabela 17 - Taxas de perda aplicáveis aos ativos sem risco identificável.

\begin{tabular}{lcc}
\hline & Período & $\%$ \\
\hline Até 6 meses & 25 \\
Mais de 6 meses, sem exceder 9 meses & 50 \\
Mais de 9 meses, sem exceder 12 meses & 75 & 100 \\
Mais de 12 meses & & $\%$ \\
\hline
\end{tabular}

Fonte: Adaptado de Circular n. 04/2004 - Banco da Espanha. 
A escala acima é aplicada a operações classificadas como de cobrança duvidosa para clientes em atraso e acumulação de valores vencidos em outras operações. Para este efeito, é considerada como a data para o cálculo do percentual de cobertura dessas transações, as operações mais antigas em atraso que não foram liquidadas, ou ativos qualificáveis como de cobrança duvidosa.

Os instrumentos de dívida classificados como duvidosos para outros motivos, que não atraso, são analisados individualmente. Sua perda é igual à diferença entre o valor registrado no ativo e o valor presente dos fluxos de caixa que se espera receber.

As instituições para cobrir as perdas inerentes a instrumentos de dívida classificadas como "risco normal" consideram a experiência histórica de perdas e outras circunstâncias conhecidas no momento da avaliação. Para estes fins, as perdas inerentes são perdas incorridas na data das demonstrações financeiras, calculadas através de procedimentos estatísticos, que não tenham sido alocados a operações específicas.

O Banco de Espanha determinou que o método e a quantidade de parâmetros que as entidades devem usar para calcular os montantes necessários para cobrir perdas por imparidade inerentes em instrumentos de dívida classificados como risco normal, que são registradas nas entidades espanholas ou se relacionam com transações em nome de residentes na Espanha registradas nas controladas no exterior. O Banco da Espanha atualiza os percentuais estimados para perdas das operações.

A estimativa geral é igual a: a) a soma do resultado da multiplicação do valor positivo ou negativo da variação durante o período da quantidade de cada uma das classes de risco $\alpha$ parâmetros que estão preocupados, mais b) a soma do produto da multiplicação do montante total das operações incluídas em cada classe de risco no final do período e as $\beta$ dos parâmetros relacionados, menos c) o montante da provisão líquida específica global produzida durante no período. Os percentuais consideram, conforme a Circular n. 04/2004, histórico e ajustes para se adaptar às atuais circunstâncias econômicas. 
Tabela $18-\beta$ e $\alpha$ das classificações de risco.

\begin{tabular}{lcc}
\hline \multicolumn{1}{c}{ Tipo de Risco } & $\boldsymbol{\beta}(\mathbf{\% )}$ & $\boldsymbol{\alpha}(\mathbf{\% )}$ \\
\hline Sem risco identificado & 0 & 0 \\
Baixo Risco & 0,6 & 0,11 \\
Médio-baixo risco & 1,5 & 0,44 \\
Médio risco & 1,8 & 0,65 \\
Médio-alto risco & 2 & 1,1 \\
Alto risco & 2,5 & 1,64 \\
\hline
\end{tabular}

Fonte: Adaptado de Circular n. 04/2004 - Banco da Espanha.

Para a estimativa de perda do risco país nos grupos de 3-6, incluem pelo menos os seguintes percentuais:

Tabela 19 - Estimativa de perda.

\begin{tabular}{cc}
\hline Grupo & $(\boldsymbol{\%})$ \\
\hline 3 & 10,1 \\
4 & 22,8 \\
5 & 83,5 \\
6 & 100 \\
\hline
\end{tabular}

Fonte: Adaptado de Circular n. 04/2004 - Banco da Espanha.

Característica consistente nos três países é a utilização de critérios que possuem variáveis de perda incorrida e perda esperada, configurando-se um modelo hibrido de estimativa de perda para as operações de créditos, como pode ser visto nas seções inerentes a Brasil e Portugal.

\section{Provisão para créditos de liquidação duvidosa em instituições financeiras brasileiras}

As provisões para créditos de liquidação duvidosa de operações de créditos são constituídas baseadas na classificação das operações de créditos por níveis de risco e as regras são definidas pela Resolução CMN n. 2.682/1999, com vigência a partir de março de 2000. Conforme Niyama e Gomes (2012), essa resolução foi editada com a finalidade de harmonizar a regulamentação local às normas e aos padrões contábeis no âmbito do Mercosul e adequá-las à evolução e à sofisticação do mercado financeiro, bem como às mudanças no perfil de crédito das operações. 
A partir da Resolução CMN n. 3.786/2009, as instituições financeiras passaram a apresentar demonstrações financeiras de mesma data-base com bases de preparação diferenciadas, uma com as práticas aprovadas pelo BACEN, e outra com base nas práticas contábeis internacionais. Assim, as instituições financeiras e demais instituições autorizadas a funcionar pelo BACEN utilizam em suas demonstrações financeiras, no contexto regulatório, o conceito de perda esperada, utilizando os critérios de constituição de provisão para créditos de liquidação duvidosa instituídas pela Resolução CMN n. 2.682/1999; e, para as demonstrações financeiras no padrão internacional, fazem uso das premissas dispostas no IAS 39, que emprega os conceitos de perda incorrida. A presente pesquisa utiliza os dados e analisa os resultados das provisões das demonstrações financeiras com as práticas regulatórias.

As estimativas baseadas no conceito de perda incorrida foram criticadas amplamente, principalmente, após a crise financeira iniciada em 2008. Para Camfferman (2013), a crise reforçou a necessidade de reconhecimento de perdas. Em março de 2013 o IASB divulgou o Exposure Draft (projeto) que faz parte das discussões para a substituição do IAS 39, que objetiva o aperfeiçoamento do reconhecimento de perdas. O modelo atual de reconhecimento de perda pelo IAS 39, para instrumentos financeiros, é baseado na premissa de perda incorrida, mas a proposta de alteração, por meio do IFRS 9, convergem para adoção de um critério de reconhecimento de perdas esperadas, dado as recorrentes críticas ao atual modelo em função de eventuais postergações de reconhecimento de perda. Dessa forma, um modelo que se aproxima ao critério regulatório.

Com base nos critérios dispostos na Resolução CMN n. 2.682/1999, as operações de créditos das instituições financeiras devem ser classificadas, por ordem crescente de risco, nos níveis de risco: AA, A, B, C, D, E, F, G, e H. A resolução determina que a responsabilidade pela classificação das operações por nível de risco é da instituição financeira, que deve utilizar critérios consistentes e verificáveis, com base em informações internas e externas. Com relação aos credores e aos garantidores, devem ser considerados: a situação econômica e financeira, o grau de endividamento, a capacidade de geração de resultados, o fluxo de caixa, a qualidade da administração, a pontualidade e o atraso nos pagamentos, as contingências, o setor de atividade econômica e o limite de crédito. Com relação à operação, as instituições financeiras devem considerar os aspectos referentes à natureza e à finalidade da transação, ao montante e às características das garantias.

A Resolução CMN n. 2.682/1999 estabelece em seu art. $4^{\circ}$, que as classificações das operações de créditos devem ser revistas: a) mensalmente, em função de atrasos no 
pagamento de parcela do principal ou dos encargos, obedecendo, no mínimo, à classificação estabelecida:

Quadro 5 - Níveis de risco.

\begin{tabular}{|c|c|}
\hline Período de atraso & Classificação risco \\
\hline 15 e 30 dias & Nível de risco B \\
\hline 31 e 60 dias & Nível de risco C \\
\hline 61 e 90 dias & Nível de risco D \\
\hline 91 e 120 dias & Nível de risco E \\
\hline 121 e 150 dias & Nível de risco $\mathrm{F}$ \\
\hline 151 e 180 dias & Nível de risco $\mathrm{G}$ \\
\hline Superior a 180 dias & Nível de risco $\mathrm{H}$ \\
\hline
\end{tabular}

Fonte: Adaptado de CMN (1999).

Além dos outros aspectos que devem ser observados:

1) Com base nas características do devedor, dos garantidores e da operação:

a) A cada seis meses, as operações de um mesmo cliente ou grupo econômico cujo montante da operação seja superior a $5 \%$ (cinco por cento) do patrimônio líquido ajustado da instituição financeira credora; e

b) A cada doze meses, todas as operações, exceto aquelas cuja responsabilidade do cliente seja inferior a $\mathrm{R} \$ 50.000,00$ (cinquenta mil reais), que são revistas em função dos atrasos a que se refere o item anterior.

Em seu art. $6^{\circ}$, a resolução determina que a provisão para créditos de liquidação duvidosa (PCLD) deve ser constituída mensalmente, em montante não inferior ao somatório calculado para carteira classificada pelo nível de risco, em decorrência da aplicação dos percentuais: 
Tabela 20 - Percentual de provisão de acordo com o nível de risco.

\begin{tabular}{cc}
\hline Nível de risco & Percentual provisão \\
\hline AA & $0,0 \%$ \\
A & $0,5 \%$ \\
B & $1,0 \%$ \\
C & $3,0 \%$ \\
D & $10,0 \%$ \\
E & $30,0 \%$ \\
F & $50,0 \%$ \\
G & $70,0 \%$ \\
H & $100,0 \%$ \\
\hline
\end{tabular}

Fonte: Adaptado de CMN (1999).

Conforme Niyama e Gomes (2012), a Resolução CMN n. 2.682/1999 representou uma alteração significativa no reconhecimento de perdas, introduzindo o conceito de perda esperada na regulamentação brasileira e uma análise prospectiva das operações de crédito. Afirmam os autores que o conceito introduzindo pela norma trouxe como impactos, dentre outros: i) melhora na qualidade de mensuração de risco em operações de crédito; ii) critérios mais conservadores para o tratamento das operações objeto de renegociação; iii) fortalecimento da adoção de sistemas de gerenciamento de risco; iv) harmonização com outros países.

Zendersky (2005) afirma que a adoção de uma escala crescente dos percentuais de provisão, variando positivamente em relação ao nível de risco da operação, torna o resultado do período mais sensível à deterioração das operações do que ao crescimento da carteira de crédito, no que se refere às despesas de provisão para créditos de liquidação duvidosa.

Para Niyama e Gomes (2012), as alterações proporcionaram a apuração de perdas em níveis compatíveis à realidade dos ativos, ou seja, diferindo da característica do conceito de perda incorrida. Conforme os autores, a provisão constituída em níveis compatíveis com o grau de risco de inadimplência da carteira, incorporando o potencial de perdas decorrente do momento econômico e não apenas após o impacto estar refletido na incapacidade de os devedores honrarem compromissos.

Em relação a outros aspectos relevantes determinados pela Resolução CMN n. 2.682/1999 quanto à baixa de operações de créditos do ativo, o art. $7^{\circ}$ estabelece que as operações de créditos classificadas no nível de risco H, há pelo menos 06 (seis) meses, e que apresentem atrasos superiores a 180 dias devem ser transferidas para conta de compensação, 
com o correspondente débito em provisão, permanecendo pelo prazo máximo de 05 (cinco) anos. No Brasil, o art. $9^{\circ}$ da referida Resolução, têm-se a proibição do reconhecimento, no resultado, de receitas ou encargos, de qualquer natureza, relativos às operações de créditos cujos pagamentos do principal ou dos encargos estejam em atraso igual ou superior a sessenta dias.

A inclusão da possibilidade da utilização de uma análise subjetiva para constituição das provisões para perda com operações de créditos por meio da alteração da regulamentação sobre a constituição de provisão para créditos de liquidação duvidosa inseriu no sistema financeiro brasileiro a discricionariedade do gestor com relação à constituição de provisões para operações de créditos. A Resolução anterior - Resolução CMN n. 1.748/1990 designava a constituição de provisão em função apenas dos atrasos nos pagamentos das operações, e com a vigência da Resolução CMN n. 2.682/1999, as instituições financeiras passaram a ter autonomia para classificar as operações de créditos em níveis de risco, utilizando critérios próprios de avaliação, que em alguma proporção possibilita a escolha dos níveis de provisão para créditos de liquidação duvidosa que sensibilizarão a carteira de crédito e o resultado, ainda que, haja a determinação que os critérios utilizados para classificação das operações de créditos devam ser consistentes e verificáveis, o que não impossibilita a subjetividade na determinação dos percentuais por meio da classificação de risco.

Adicionalmente, outra oportunidade existente na regulamentação que possibilita a discricionariedade dos gestores sobre a constituição de provisão para créditos de liquidação duvidosa é a determinação que o montante de provisão deve ser, no mínimo, igual ao somatório dos percentuais aplicados sobre os saldos das operações classificadas em cada nível de risco, havendo a oportunidade para que as instituições financeiras constituam provisões excedentes em relação ao mínimo requerido.

A subjetividade existente na regulamentação dá a possibilidade de utilização das despesas de provisão para créditos de liquidação duvidosa para a realização de gerenciamento de resultados. Atualmente, a regulamentação das provisões utiliza critérios que podem ser considerados como modelo híbrido, tendo em vista a utilização de regras e princípios. 